$5 B$
363

C2 


$$
\text { ชิ }
$$






CALIFORNIA STATE COMMISSION OF HORTICULTURE

\section{APPLE GROWING IN CALIFORNIA}

California State Printing Office 
 \\ OFFICERS OF THE CALIFORNIA STATE COMMISSION OF HORTICULTURE.}

EXECUTIVE OFFICE.

Capitol Building, Sacramento.

A. J. COOK

Commissioner GEO. P. WELDON

Chief Deputy Commissioner

E. J. VOSLER Secretary

MISS MAUDE HIETT Clerk

MRS. N. MITCHELL

Stenographer

INSECTARY DIVISION.

Capitol Park, Sacramento.

HARRY S. SMITH Superintendent HENRY L. VIERECK Assistant Superintendent E. J. BRANIGAN

O. W. NEWMAN Field Deputy MRS. D. STEPHENS Assistant Stenographer

QUARANTINE DIVISION.

San Francisco Office: Room 11, Ferry Building.

FREDERICK MASKEW

Chief Deputy Quarantine Officer GEO. COMPERE -Chief Quarantine Inspector

B. B. WHITNEY Quarantine Inspector

L. A. WHITNEY Quarantine Inspector ARCHIE CHATTERLEY Quarantine Inspector STEWART CHATTERLEY Quarantine Inspector MISS CLARE DUTTON Stenographer and Clerk

\section{Los Angeles Office: Floor 9, Hall of Records.}

A. S. HOYT Deputy Quarantine Officer C. H. VARY Quarantine Inspector LEE A. STRONG Quarantine Inspector

H. V. M. HALL Quarantine Inspector 
THE STATE COMMISSION OF HORTICULTURE

\title{
Apple Growing in California
}

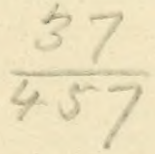

A Practical Treatise Designed to Cover Some of the Important Phases of Apple Culture Within the State

\author{
By GEO. P. WELDON
}

Chief Deputy State Commissioner of Horticulture 


\section{TABLE OF CON'TENTS.}

$\begin{array}{ccr}\text { CHAPTER I. } & \text { PAGE. } \\ \text { STATISTICS } & \text { CHAPTER II. } & \\ \text { VARIETIES } & \text { CHAPTER III. } & \end{array}$

PROPAGATION OF THE APPLE

Chapter IV.

SELECTION OF TREES FOR PLANTING__._.

Chapter V.

SOILS AND THEIR PREPARATION FOR PLANTING____._. 38

CHAPTER VI.

SETTING AND CARING FOR THE YOUNG TREES $\ldots$

Chapter Vil.

PRUNING

CHAPTER VIII.

TOP-WORKING APPLE TREES

INTERCROPPING

Chapter IX.

ChAPTER $\mathrm{X}$.

IRRIGATION, CULTIVATION_COVER CROPS AND FERTILIZERS _._____ 63

CHAPTER XI.

THINNING

Снартев XI.

Chapter XII.

INJURY AND PROTECTION OF APPLES FROM FREEZING_........ T0

ChAPTER XIII.

SPRAYING THE APPLE

CHAPTER XIV.

INSECT PESTS OF THE APPLE_

CHAPTER XV.

DISEASES OF THE APPLE

PICKING, GRADING AND PACKING

Chapter XVII.

F:Y-PRODUCTS

Chapter XVIII.

PRODUCTION, CONSUMPTION AND RECIPES 104

Chapter Xix.

INSECTICIDES AND FUNGICIDES

\section{D. of $D_{0}$ : \\ I: 295}




\section{PREFACE.}

The great importanee of the apple in om state. the many failures among those who have attempted to srow this fruit, the common opinion that an apple orchard can not be made a paying proposition, and the hopeless neglect and conseguent failure to produce what might be beautiful and profitable orchards, together with a dearth of literature on the subject, are some of the things that induced the author to write this little book. It is published with a realization of its incompleteness and possible errors, but if it will in a small way, at least, serve as a guide to future profitable apple eulture in California, the efforts put forth will in no way be regretted.

While primarily a treatise on apple culture, several of the chapters are designed to teach lessons that will be valuable in the eulture of other fruits: For example, chapters on Pruning. Intercropping and Cover Crops.

I wish to express thanks to I)r. A. J. ('ook, under whose direction the investigations were conducted, and who has at all times cooperated with me in the work. Iis valuable assistance in reading the manuseript is appreciated.

Thanks are also due Prof. A. V. Stubenranceh. Pomologist of the State Iniversity at Berkeley, MLr. W. IT. Volek, County IIorticultural Commissioner of Santa Cruz County and Mr. WT. S. Ballard. Pathologist, Fruit-Disease Investigations, United States Department of Agriculture, each of whom kindly read parts of my mannseript; also to Mr. E. J. Vosler, Secretary of the State Commission of Horticulture and Mr. II. S. Smith. Superintendent of the State Insectary, for the same courtesy.

For illustrations I am indebted to the State University, Mr. C. B. Weeks, County Horticultural Commissioner of Tehama County, Mr. O. E. Bremner, County Horticultural Commissioner of Sonoma County, and Mr. J. F. Benton of Arcata.

Sacramento, California, November 5, 1914.

GEO. P. WELDON. 



\section{APPLE GROWING IN CALIFORNIA.}

CHAPTER I.

\section{STATISTICS.}

There is no more cosmopolitan fruit among the long list grown, than the apple. It adapts itself to the cold elimates of the north as well as to the more temperate renions farther south. Practically erery state in the Union boasts of some places where apples can be produced, and as far north on the eontinent as British Columbia we find them doing remarkably well. The climate and soil in many parts of California are arlmirably suited to the erowing of this fruit. Prof. E. o. Wiekson. in his " Califormia Fruits," divides the state into five rexpions. viz: northern coast region, central coast region, interior valleys and foothills, momtain valleys and plateaus, and southern California, and gives a long list of varieties that are adapted to the diversified conditions of these regions. The central coast region has so far ploduced a rerrereat part of the state's output of apples, in fact is the only region which has taken up apple orcharding on a large seale. With splendid transportation facilities and with conditions of soil and climate such that certain varieties have done well, Santa Cruz and Sonoma countirs, despite their low elevation and frepuent fogs, have produred Yellow Bellflowers. Yellow Newtowns and Gravensteins, that have made them famous. The northern coast region. including within its borders Mendocino and IImmboldt counties, is fast coming to the front, and the vast region classified under the name of "mountain valleys and plateaus" enntains an abundance of land upon which apples of superiof cpuality ("an be grown. From an elevation of abont 2,000 to 6,000 feet along the sierrat Nevada range may be seen orehards and remmants of orehards in placetically all of the counties which extend into these momntains. Fin. 1 shows an orchard at an elevation of about 5,0(0) feet. 'Transportation facilities are not such at present as to faror these sections, and since the markets are well supplied with shipments from Watsonville and other railroad points, the pioneer orchardists of the mountains have been forceel to give up their practice of hauling the cropl a long distance and the orehards no longer paying are negleceted. Many splendid trees in some of these old remmants of orehards may still he seen. indicative of the possibilities of apple culture in the momntainous parts of the state.

The economic value of the apple is probably greater than that of any other fruit. Its cosmopolitan nature has made it a favorite for planting. and its food value is such as to make it prized above all on fruits. The "ry of orerproduction has rume in our ears until we wonder sometimes that any one has the nerve to go into the business. Despite this ery there is still a good profit to be made from the well arred for oreharel of good varieties, well grown and parked. The apple husiness of the future must go to those sections where the fruit can be produced best, tor small. enarly apples will not pay for the expense of errowing them, while the 
APPLE GROWING IN CALIFORNIA.

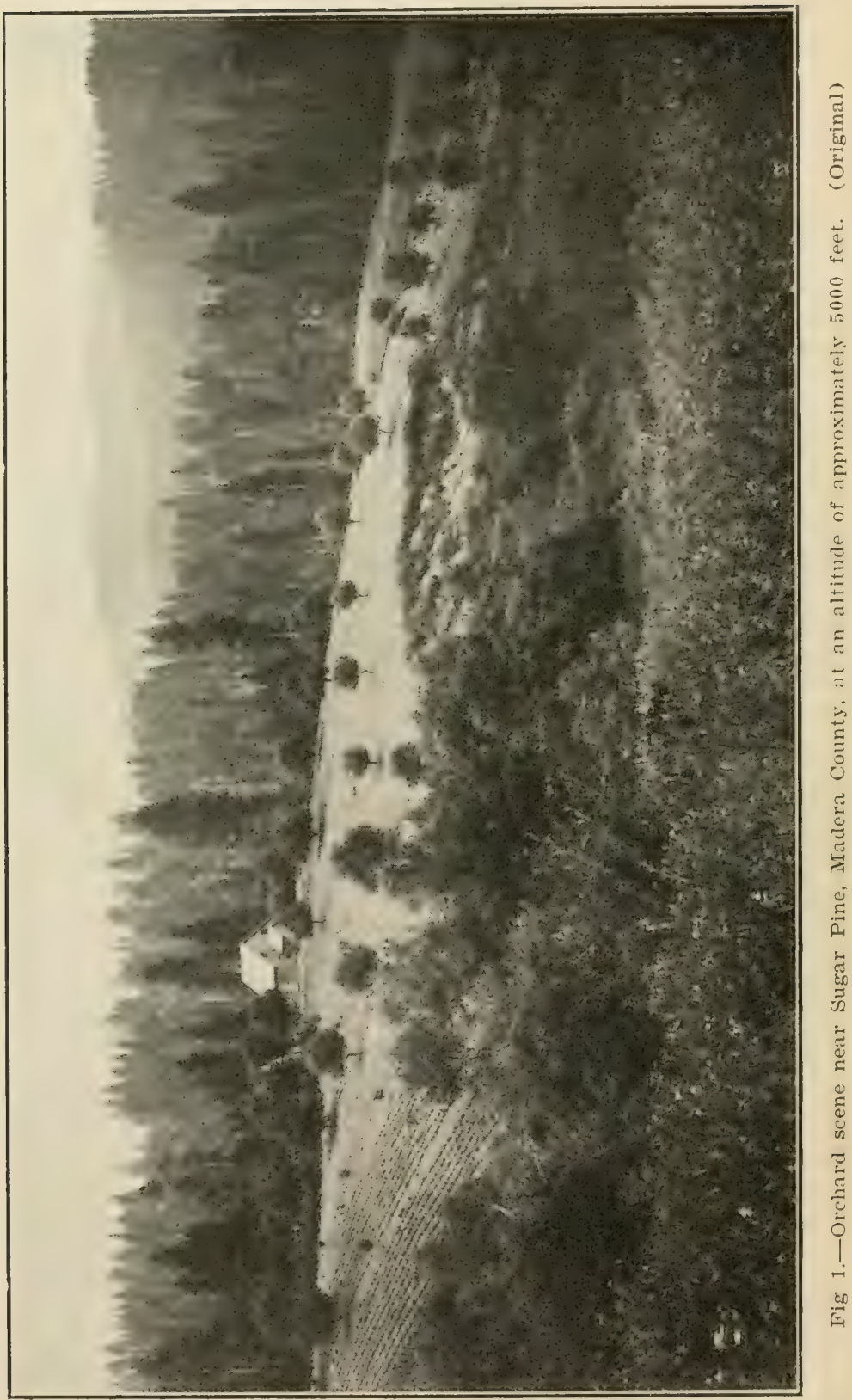


finer erades will command a handsome price. Tndesirable varieties in each loeality must be weded out, either by their removal entirely or hy grafting them over to desirable varieties. The orchard containing as many varieties as there are trees must give way to one of only a few of the best. Sperialization is the keynote to suecess in the apple business. as elsewhere, and only the sections which unite in the growing of a few well adapted varieties can hope to gain a reputation for their produrt and the market which as a consequence will be created.

It is a well known fact that the acreage planted to apple trees in recent years has been very large. and this fact has bean a cause for alarm among those already in the business and has discouraged plantinen among others. One of the whef factors limiting the production of apples

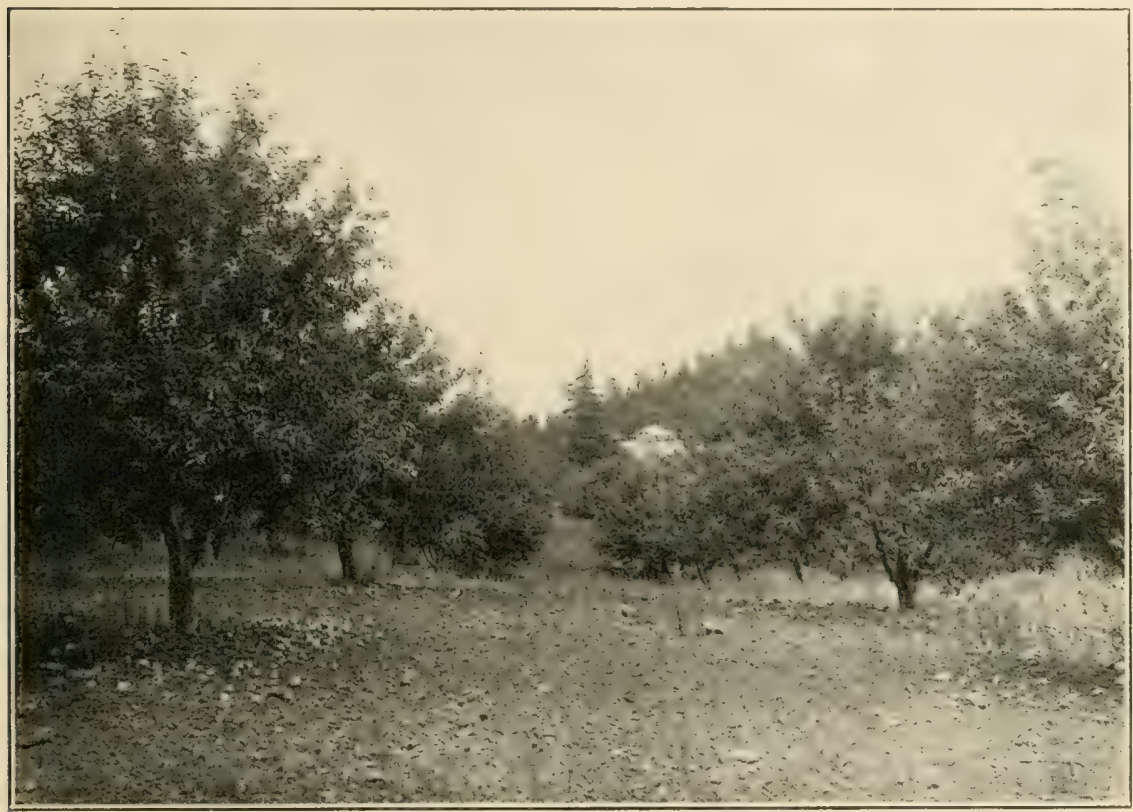

Fig. 2.-Orchard scene near Julian, San Diego County. (Original)

is frost, and practically every state where they are grown is subject to periodical injury from it, and hecause the acreage of this frut is great. it does not necessarily follow that the crop will be great every season. and prices low as a conseguenee. This one factor, frost. has driven many a man in the apple business to the "wall," and no doubt will continue to drive others, for planting in frost-subjected aleas. heranse of an oceasional good crop, will never entirely cease. California can hoast of areas that are as free from killing spring frosts as any that may be found, and one who is growing fruit of any kind may feel reasonably sure of a fairly good crop anmully. This assurance of an anmual epop in many parts of california is not possessed by states less fortunately situated, and is a great point in her favor. 
At the present time the apple business is somewhat discouraging, but there is no reason to doubt that the time will come when it will be good again. Periods of low prices always have a tendeney to weed out many unprofitable orchards, thus decreasing the acreage to the decided advantage of those that are properly cared for or more favorably situated.

In the annual reports received from the county horticultural commissioners for the past rear, the bearing and non-bearing acreage of apples in the various counties where these officials are at work, was given. A tahle, which follows, has been compiled, showing the comnties from which these reports came, and the number of acres in each case.

TABLE GIVING ACREAGE OF APPLES.

County

Alameda

Butte

Contra Costa

El Dorado

Glenn

Humbolit

Inyo

Kern

Lake

Los Angeles

Madera

Mendocino

Merced

Modoe

Monterey

Nevada

I'lacer

Riverside

Sacramento

San Benito

San Bernardino

San Diego

Santa Barbara

Santa Clara

Santa Cruz

Shast a

Siskiyou

Sonomit

Stanislaus

Sutter

Tehama

Tulare

Tolo

Yuba

Total
Bearing

Non-bearing

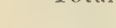
(2) 
Following is the list of questions and the table, in which the $11 m m$ meres in first column correspond to those in list:

1. How many packed boxes of apples per tree do you consider an average erop for your orchard?

2. Iow many packed boxes per tree do your heaviest hearing trees produce?

3. How old are your trees?

4. What per cent of your apple crop is packed?

5. What per cent is dried?

6. What per cent is made into eider, jelly, vinegar, or sold locally? Indicate which.

7. What is the average price per pound net to the erower, for dried apples?

8. What is the average price per box to the grower for packed apples?

9. What is the approximate elevation of your orchard?

10. Do you practice thinning?

11. Is your orehard irrigated? 


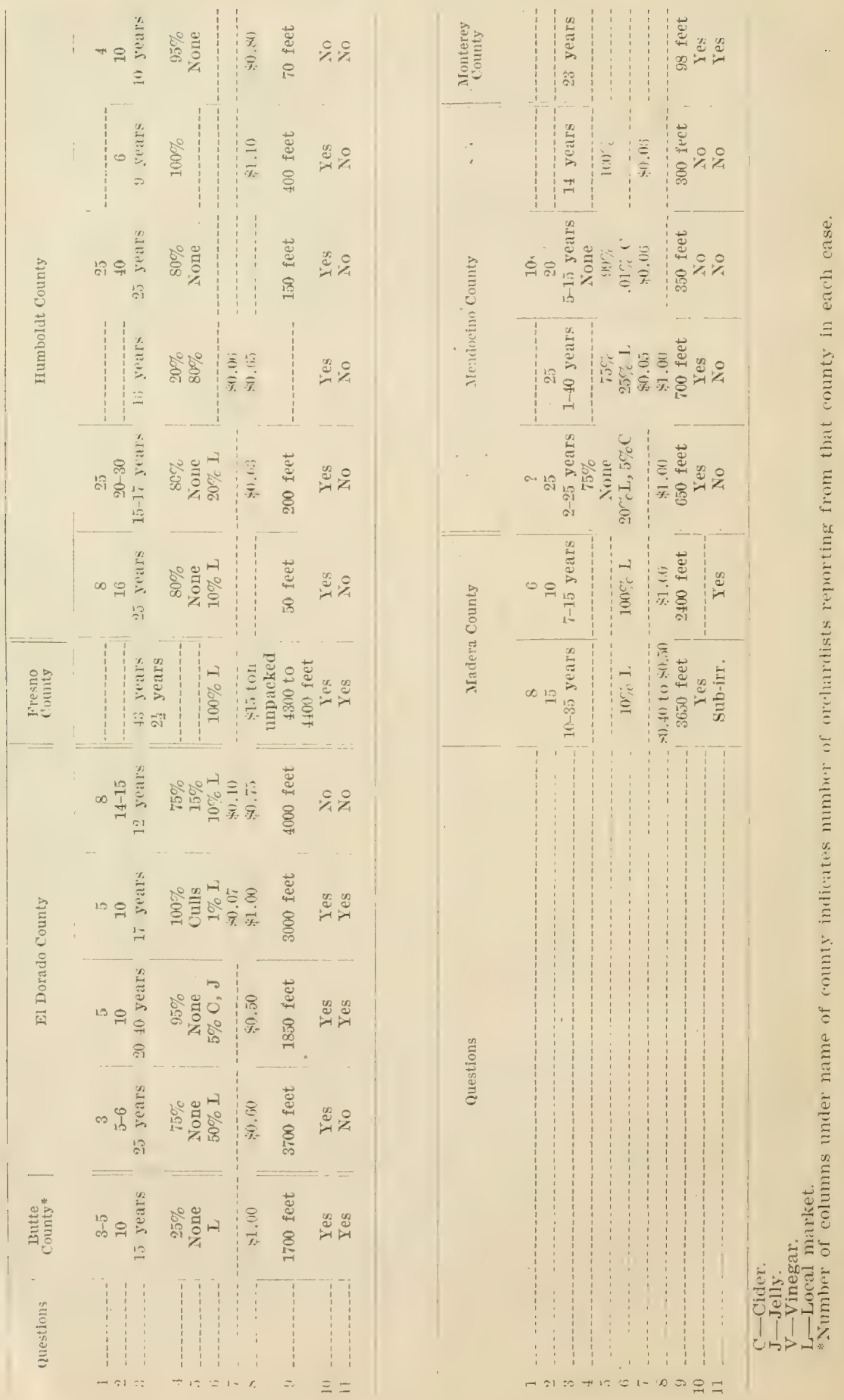




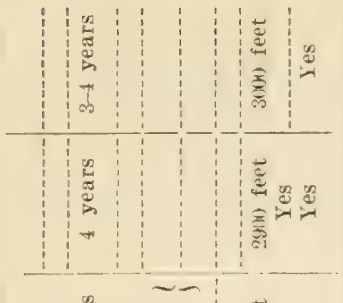

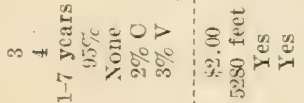

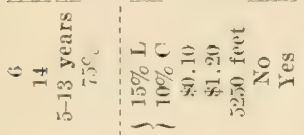

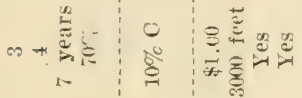

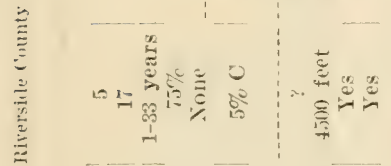

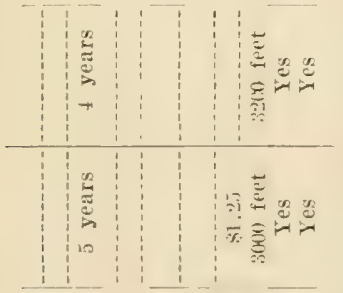

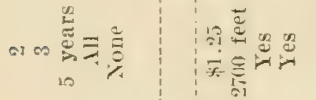

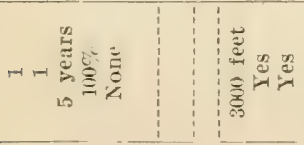

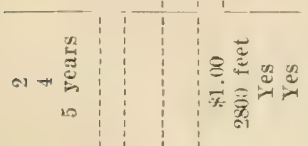

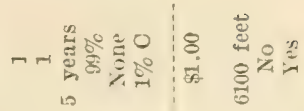

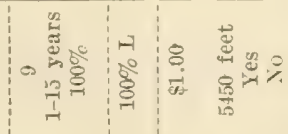

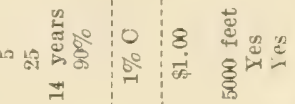

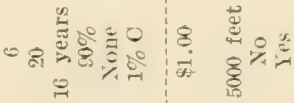

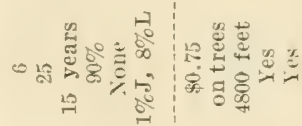

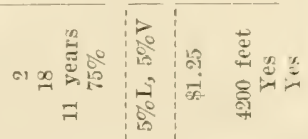

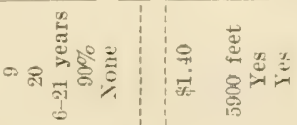

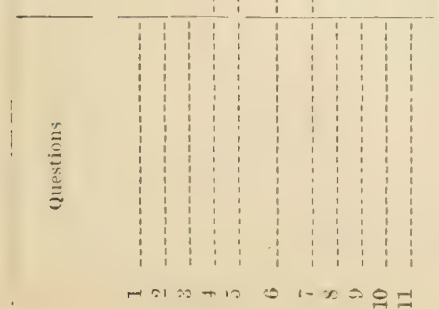




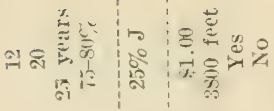

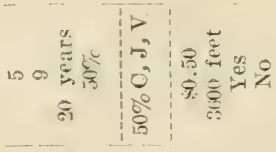

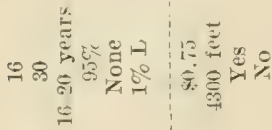

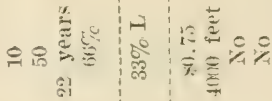

要

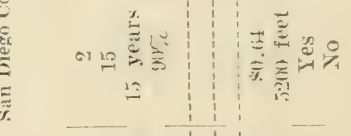

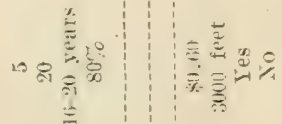

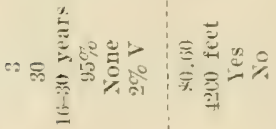

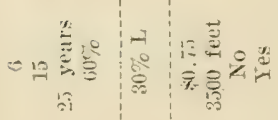

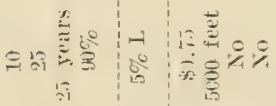

苋

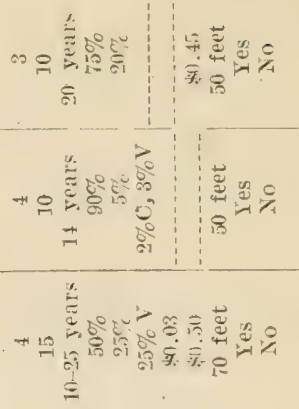

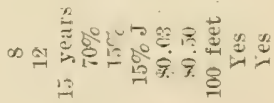

.

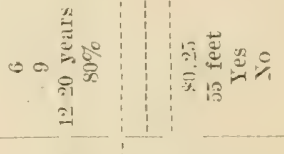

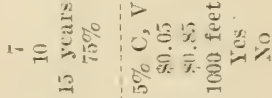

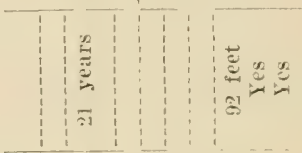

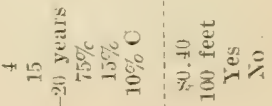
且

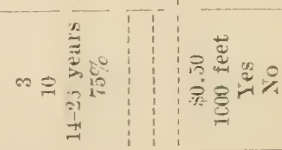

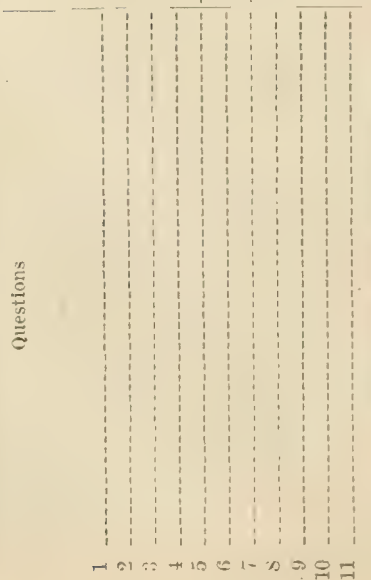




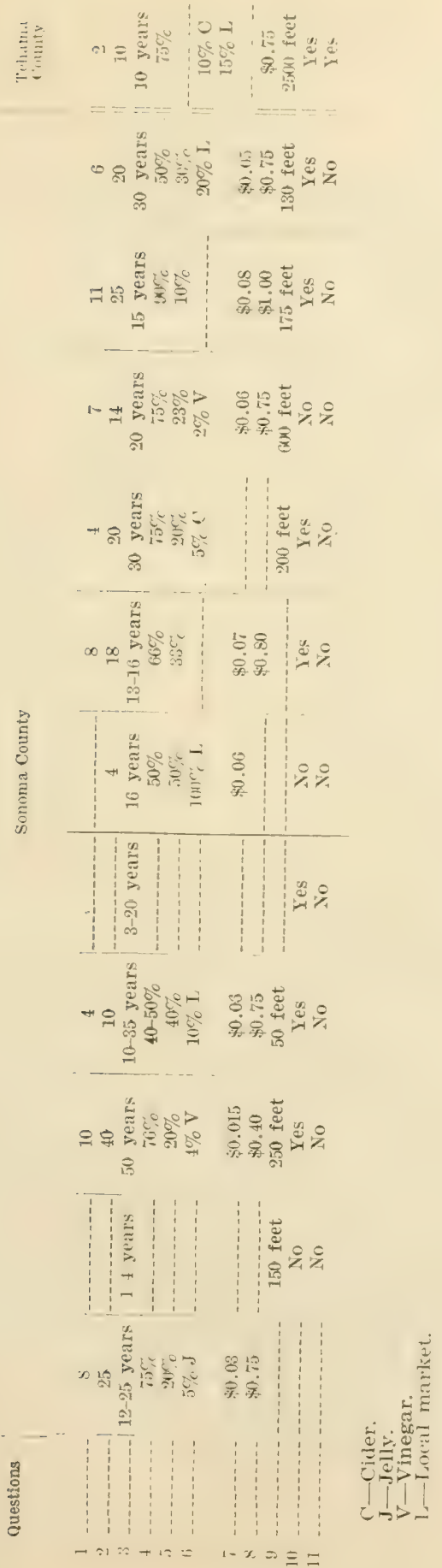


CHAPTER II.

\section{VARIETIES.}

It is interesting to note in connection with first choice of varieties in answer to question No. 12 (Name your leading varieties in the order of their importance), that one man, reporting from Butte County, places Black $B c u$ first. Four reporting from El Dorado-and no two agreeing-gave their first choice as follows: Rome Beauty, Esopus, Bulduin and sutton. One man from Fresno reports Fameuse as his first choice. Humboldt County is represented by six growers, giving their first choice as Wagener, liing, Esopus, Yellow Bellflower, and two favored Rhode Island Greening. Two reports from Madera County were received, both giving Winter Pearmain as the leading variety for this section. In Mendocino County the following varieties are said to he the best by four who answered the questions: Jonathan, Swaar, King and Baldwin. One report from Monterey County places the Yellow Newtown first. Eleven orchardists reported from Riverside County, riving a leading place to the following: King David, Esopus, Rhode Island Greening, three favored Rome Beauty and five Delicious. Eight orchardists were heard from in San Bernardino County, one giving the Jonathan first place, two Winesap and five Rome Beauty. From San Diego County nine reports came, one giving Jonathan as the leading variety, one Julian Duchess, one Paragon, three Yellow Newtown, and three Ycllow Bcllflower. As would naturally be expected, only two varieties were given first place by nine of the leading orchardists reporting from Santa Cruz County; six favored the Yellow Newtown and ihree the Yellow Bellflower.

The second county in importance from the standpoint of produc1ion, viz, Sonoma, is represented in these answers by eleven growers, eight of whom favor the Gravenstein, one the Alexander, one the Rome Beauty and one the Yellow Newtown. One report from Tehama County gives the Yellow Newtown first place.

The following is a complete list of the varieties, arranged alphabetically as they were sent in, making a total of forty-eight in all, reporter? upon. Brief descriptions of twenty of these and illustrations of nine of the best follow, also a supplementary list of varieties not reported upon hy growers, but most of which the writer has seen growing somewhere ii the state, and which are recommended for trial by those who are experimenting with varieties. Thus a total of seventy-two varieties, not including the lists of summer varieties and crabs, is given. This contains practically all varieties commonly found, and it is hoped may serve as a guide in the selection of suitable kinds for future planting by some to whom this book may find its way. 
VARIETIES.

\begin{tabular}{|c|c|c|}
\hline Alexander & Gravenstein & lied l'earmain \\
\hline Arkansas & Grimes & lied Winter \\
\hline Arkansas Black & Ifoorer & Rhode Island Greening \\
\hline Baldwin & Jonathan & Rome Beruty \\
\hline Banana & Julian Duchess & Smith \\
\hline Ben Davis & King & Stark \\
\hline Black Ben & King David & Stayman Winesap \\
\hline Champion & Lankford & Sutton \\
\hline Cook's Seedling & Lawver & Swaar \\
\hline Delaware Red & MeIntosh & 'I'wenty Ounce \\
\hline Delicious & Minkler & IVagener \\
\hline Esopus & Missouri Pippin & White I'ippin \\
\hline Fall Pippin & Orange Pippin & Winesap \\
\hline Fallawater & Ortley & Winter Pearmain \\
\hline Fameuse & Paragon & Yellow Bellflower \\
\hline Gloria Mundi & Red Astrachan & Yellow Newtown \\
\hline
\end{tabular}

SUPPLEMENTARY LIST.

Bailey Sweet

Bietigheimer

Canada Red

Keswick Codling

Maiden Bhush

Mamn

McMahon White

Northern Spy

Northwestern

Pewankee

I'lum Cider

Ralls
IRambo

Romanite

Sheeprose

sheriff

s'mokehouse

'I'olman

Utter

Walbridge

IVealthy

Wolf River

Iork Imperial

\section{SUMMER VARIETIES.}

'The (x)eptionally early season for ripening of all fruits in parts of Califormia opens ip the prssibility of growing summer varieties of apples that will reach the markets earlier than those from any other of our apple growing states. With San Franciseo, Los Angeles, Sacramento and other laree cities at hand, there should he a good local demand. For a ereat many years the Sacramento Valley river bottom below Sacramento has grown Red Astrachans and other summer varieties to good advantage. The sevele attack of the colling moth has probably done more toward discouraging growers than anything else. As this pest is entirely under the control of those who take the necessary pains to fight it in the proper way-as discussed in the chapter on "Insect Pests of the Apple" - there is no good reason why it shomld put any one out of business. With proper attention to pruning, splaying and rotting out hlight, along with the proper handling of the soil, much greater returns should he realized than those of the average grower at present.

The following list of varjeties is printed in the order of their ripening. They are all good, each one having some speral chatederisties to commend it:

Early Harvest

Oldenburg

Red June
Yellow Transparent

Red Astrachan

C'henango 
CRAB APPLES.

('rab apples will always he prizod by many for making jelly, pickling and preserving purposes. To those who wish to set out a few trees the following list of varieties is recommended:

$$
\begin{aligned}
& \text { Florence } \\
& \text { Hyslop } \\
& \text { Martha }
\end{aligned}
$$

Siberian, Red or Yellow

'Transcendent

Whitney

ARKANSAS.

The above variety is probably better known under the name of Mammoth Black Twig. and is grown only to a very limited extent in the state. It is of the Winesap type, probably a seedling from it, but of somewhat inferior quality. The keeping qualities are about the same. Inder some conditions it is quite subject to the Baldwin spot disease.

The trees are very large and thrifty and are inclined to be uncertain bearers.

\section{ARKANSAS BLACK.}

This rariety closely resembles the Winesap and is thought to be a seedling from it. In some parts of the state it is quite a popular variety, especially in southern California. It takes on a very deep red "olor. which polishes beautifully, making a good showing on the fruit stands, and usually commanding a ready sale. Quality is fair but somewhat coarse. Keeping qualities are excellent.

The trees are thifty growers as a rule, but are inclined to bear lightly in some sections of the country. Whether or not this applies to our ('alifornia conditions the writer has been unable to determine.

\section{BALDWIN.}

There are few finer apples than this variety when at its prime. So far it has been grown to a limited extent in the state, being subject to an olsenre disease known as Baldwin spot, which very often ruins it for market. In the East it is considered to be one of the standards. In a few favored localities in the mountains of California it has been found doing quite well, and in Sonoma County quite a large acreage has been planted, and with a few of the orchardists it is a popular variety.

'The trees are strong growers.

\section{BLACK BEN.}

While in times past the old Ben Davis apple has not only been a great producer but a money maker as well, there is little exense at this time of keen competition among growers of superior varieties for planting it. Its place may be taken by the far superior Black Ben or Gano. While the quality of this apple is little if any better than the first mentioned, the beautiful color makes it a good seller. It is not good judgment to advertise a fruit because of color-not taking into consideration the quality - yet as long as people prefer a red apple regardless of what is inside the skin, this will be a favorite variety. The keeping qualities are on a par with those of the common Ben Davis.

Trees are ordiuarily healthy and thrifty growers, and are inclined to bear regularly and heavily. If one wants to plant a Ben Davis apple, and still have a variety that sells well, this one should commend itself and should do well in sections where color attains its maximum in varieties. 


\section{DELICIOUS.}

(Fig. 3.)

T'his being one of our newest varieties, has not been tested in the state sufficiently to determine its true value. It is howevere quite promising in eretain parts of the foothils and mombanous sections of southern California. The quality is of the best and there are few

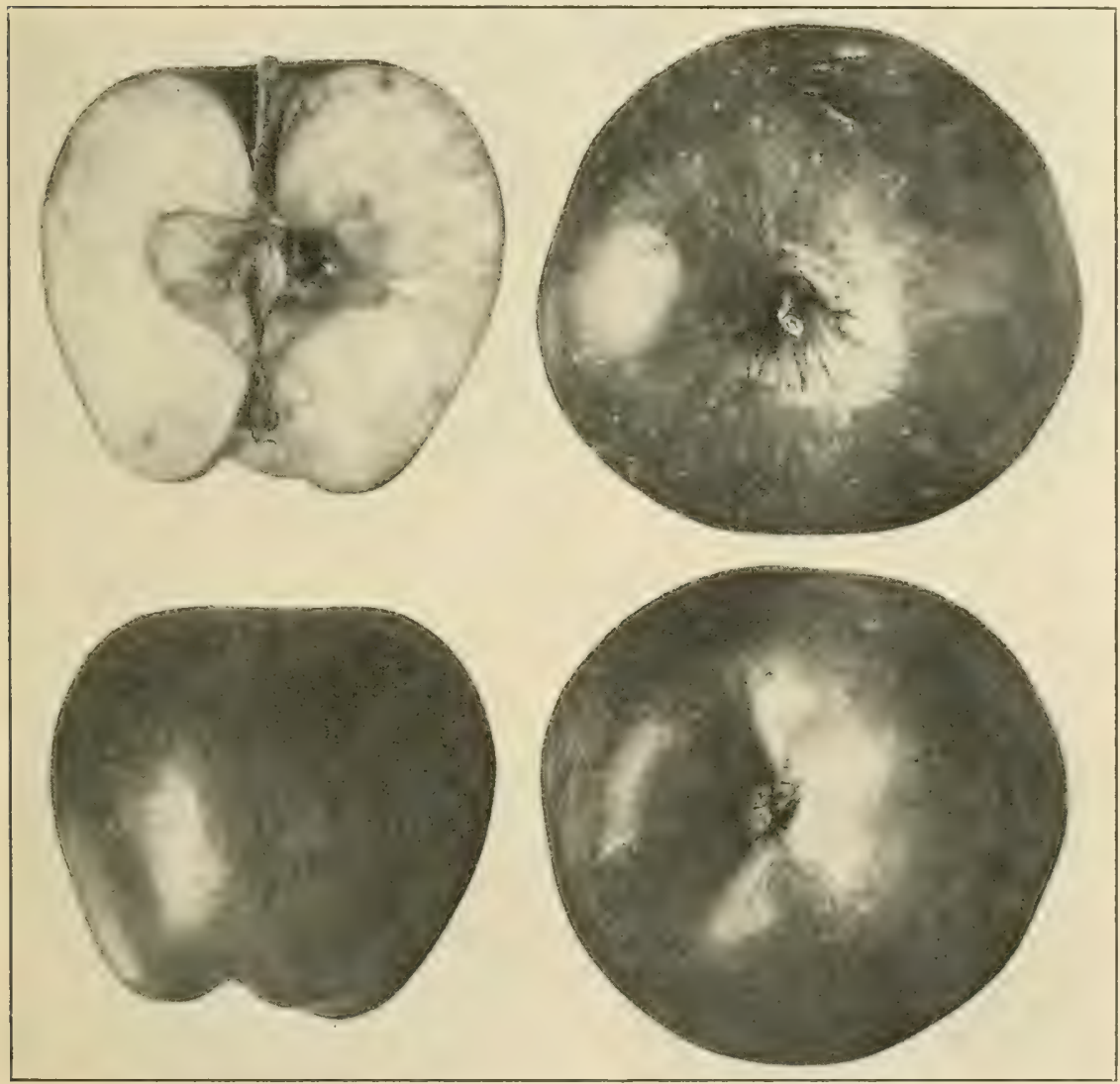

Fig. 3.-The Delicious. (Original)

apples more juicy and pleasint to the taste than this one. when in its

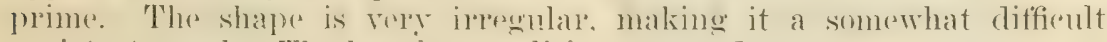
variety to pack. The keeping qualities are good.

Where this variety has been observed in the state, trees have done well, and have come into bearing quite early. Whether or not it will be a steady beatere remains to be seen. Indieations at present are that it will be one of onr best varieties in rertain sections. Fiemere 4 shows a fine tree of this valdety in the Frank Femmons orehald mear Oakhurst. 


\section{GRAVENSTEIN.}

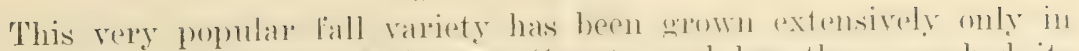
the Sebastopol seretion of Sonoma county and has there pearehed its greatest perfection. It has bexen found doinge well in mamy parts of the:

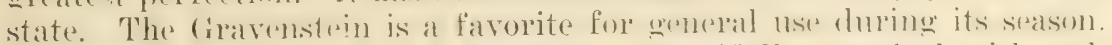

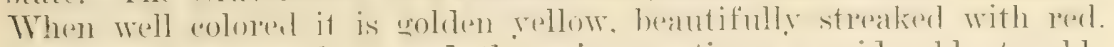
The stem is very short and there is sometimes considerable trouble experienced with the doppring of the fruit before it is ripe. The losis

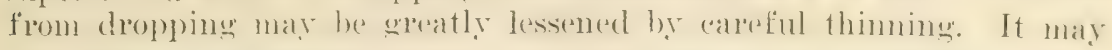

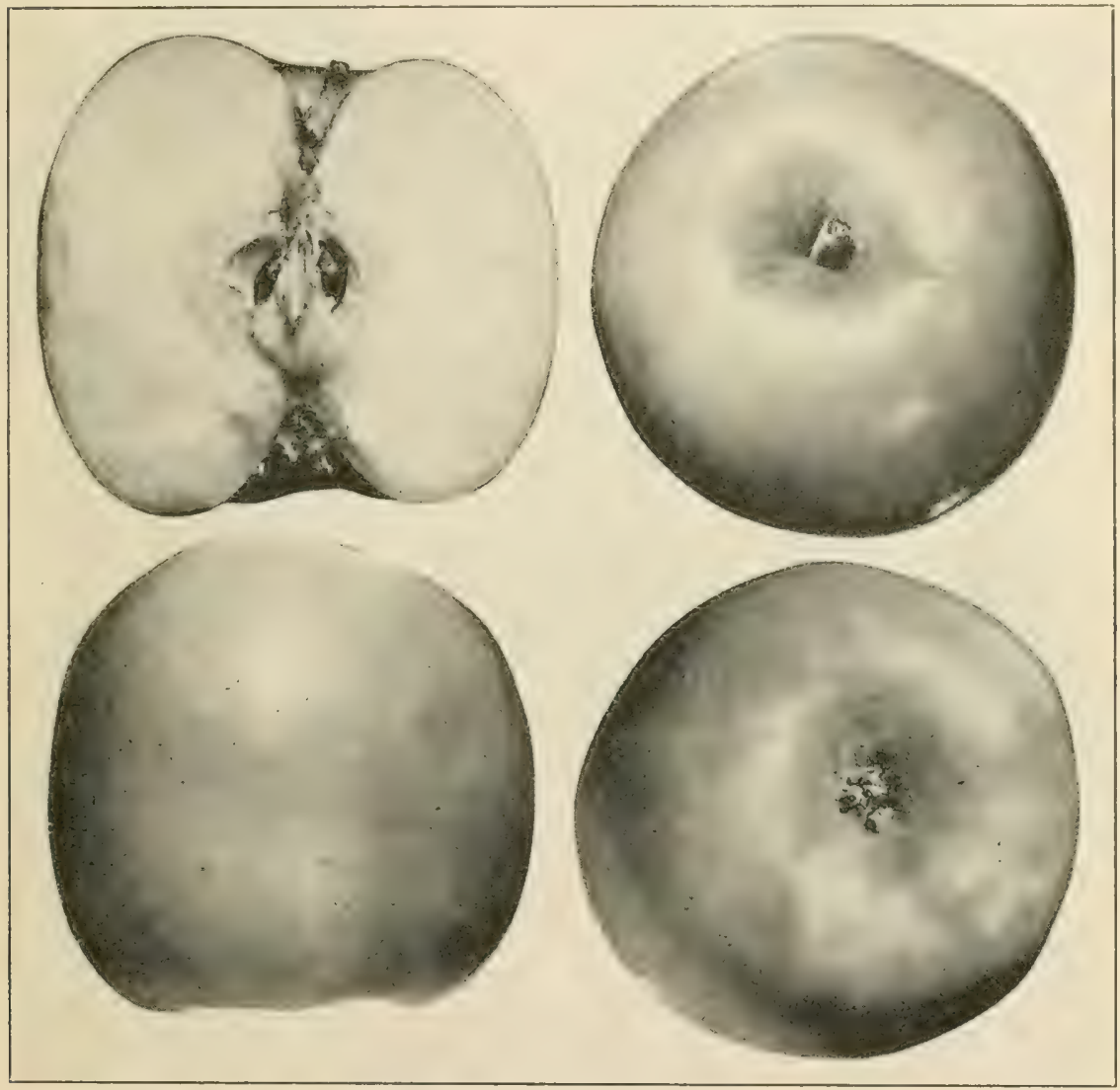

Fig. 6.-The Grimes. (Original)

be kept in cold storage for two or three months, but is inclined to go down rapidly upon being removed.

In California the trees are nsually thrifty and inclined to make ruite a strong, heavy growth.

The great suceess that has come to the alpple growers of Sonoma Comnty in growing this varjety has made it standard for that section. and has illustrated the value of specializing in the apple busines's.

\section{GRIMES."}

During the investigations preparatory to the publication of this work, the above apple has not heen commonily found erowing in the state. 
and is deserving of trial by those who are experimesting with varieties. as it is a showy apple of excellent quality, being popular both for eating and cooking purposes. Like most other apples of a light color it is sommohat delicate and must be hamdled with calre. Kerpong qualities

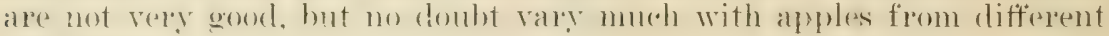
locialitios.

The trees are fairly thrifty when grown on soil suited to them.

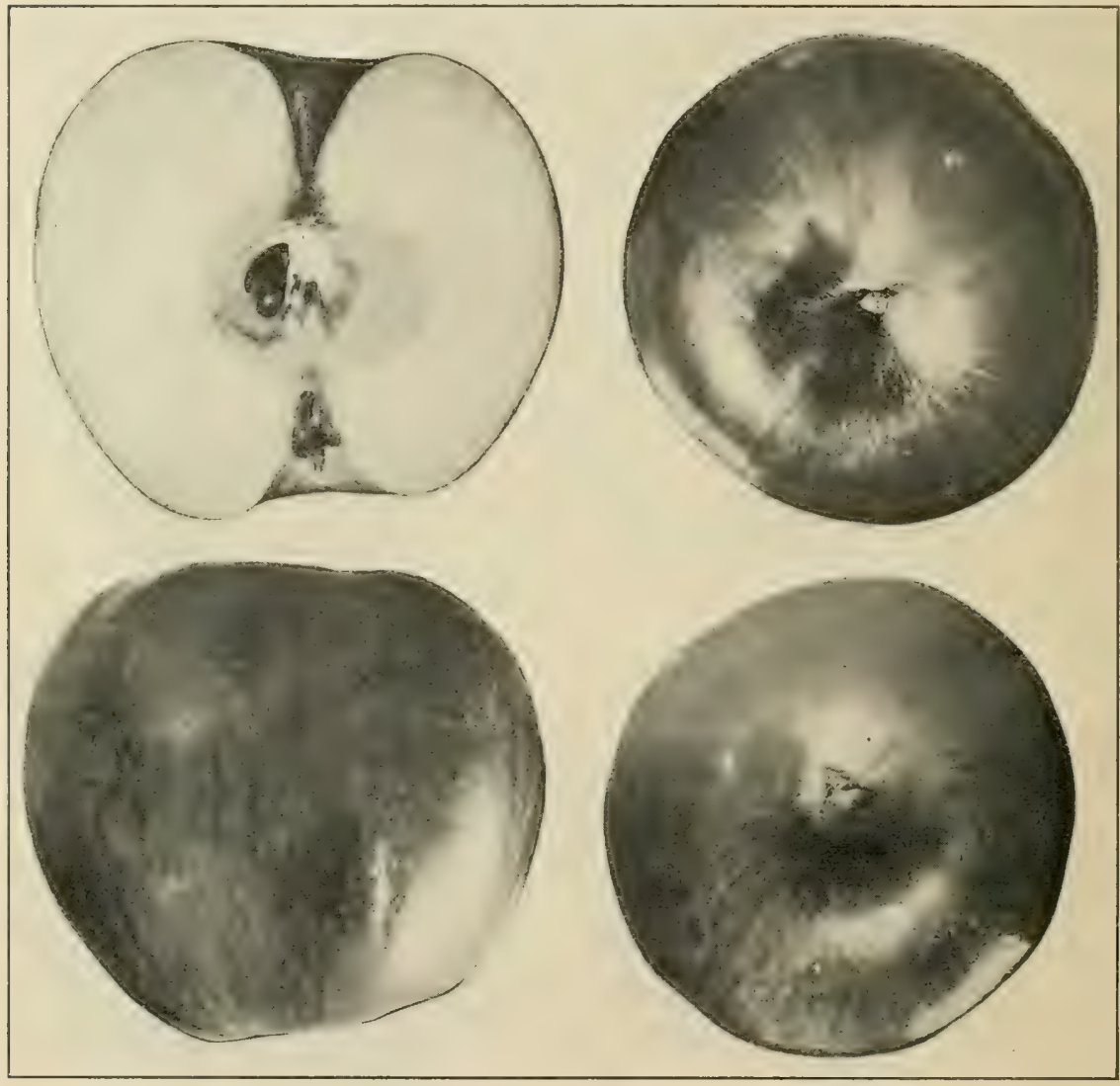

Fig. T.-The Jonathan. (Original)

Only an oceasional men has been obsered in this state, but on these some rery fine specomens were growing. It is recommended for trial in the mountain sections, especially of southern California.

\section{JONATHAN.}

(Fig. 7.)

'This excellent variety has not been grown extensively in the state, but there are places in Riverside, Sam Bermardino, San Diego, El Do-

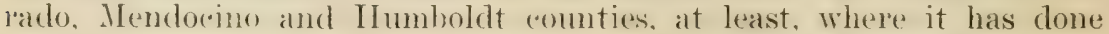
well. Its beantiful rod color. ommbined with exoellent quality makes it 
a favorite. When picked before too ripe it is a fairly good keeper. being in its prime during the holidays. In storage it is subject to a romelition known as . Jonathan spot, and should not he helel lome after the first of Jamuary.

'The tree is inclined to be small under inost conditions, and it should

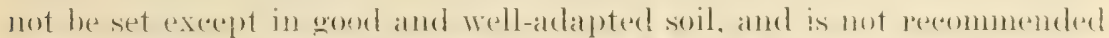

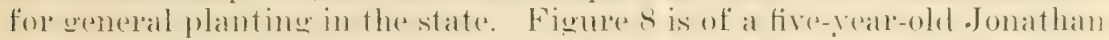
tree near Beammont, and Figure 9 of an older tree, well loaded with

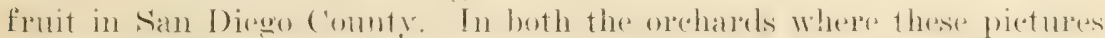
were taken the trees had made a spelendid. thrifiy erowth. and the fruit they produced was of the best. Seme splendid. Woll-eoloped spexomens

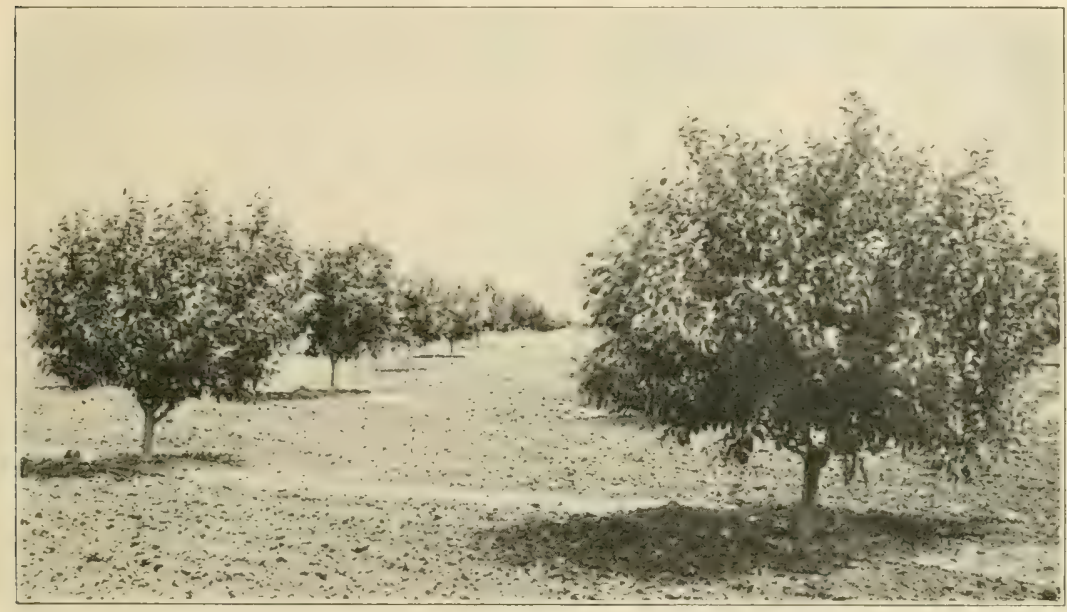

Fis. S.-Fine specimens of Jomathan trees near Beatumont, Riverside County. (Original)

have heen received from the .J. E. Hassler orchard at Placerville. The excellence that this varicty attains in Utah and Colorado, and the highest market propes that are received by growers in these states, makr it clesimable that it be grown in california omly where it will attain somewhere near the perfection that it does there. In general it is a fairly good producer, coming into bearing early and maturing crons with great regularity.

Trees shomld be prumed heavily for the first five years, and the wroatest strength of soaffold branches developed. as they have a tendeney to grow slender and willow-like, thus being unable to hold up a heavy load of fruit to the best advantage.

\section{KING DAVID.}

This beantifully colored variety is becoming quite popular in somesese tions of the state. hut as ret has not been thoromehly tested out undere California conditions. In some of the newer sections of Riverside and 
San Bernardino counties it is heing planted quite extensively. The appearance is strikingly like that of the Jonathan, but the flavor and quality are somewhat inferior.

It is fou soon to predict what the future for this rariety will be. So far it has done well from thr standpoint of growth of trees and production of fruit.

\section{ORTLEY.}

The (ontley or White Bellfower does rematkably well in parts of the foothill region. In Placer and Mariposa counties this variety has

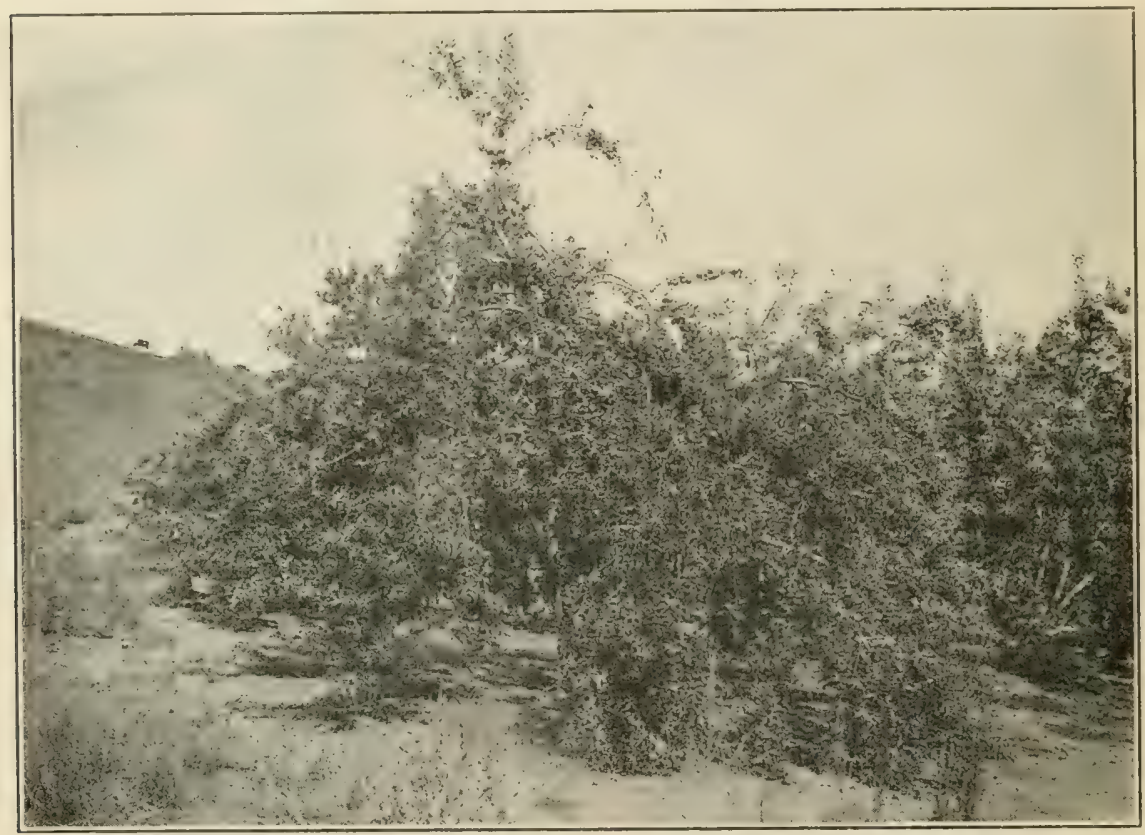

Fig. 9.-Well-1oaded Jonathan tree near Julian, San Diego County. (Original)

attained a high degues of rivellences and apples have been soleght after for table use. It is an alpple similar to the Yollow Bellfower, but of better quality. Like many of the light skimed varieties it is exceedingly delicate and suserptible to limb sears and blemishes from other injuries. The season is about with that of the. Jomathan and the two varieties together on the table make a veritable bouquet.

The trees are normally thrifty and good bearers. 


\section{ROME BEAUTY}

The Rome beanty is quite a general favorite for planting in eretain secetions of california. Where it is known to do well. When highly colored it is one of our finest appearing apples. Flesh is rery firm and of geod quality. The keeping qualities are of the best and spencimens may be held over from one season to another. There are few apples that command a higher pride than this one when in its prime.

The trees are inclined to be somewhat small, and of upright habits

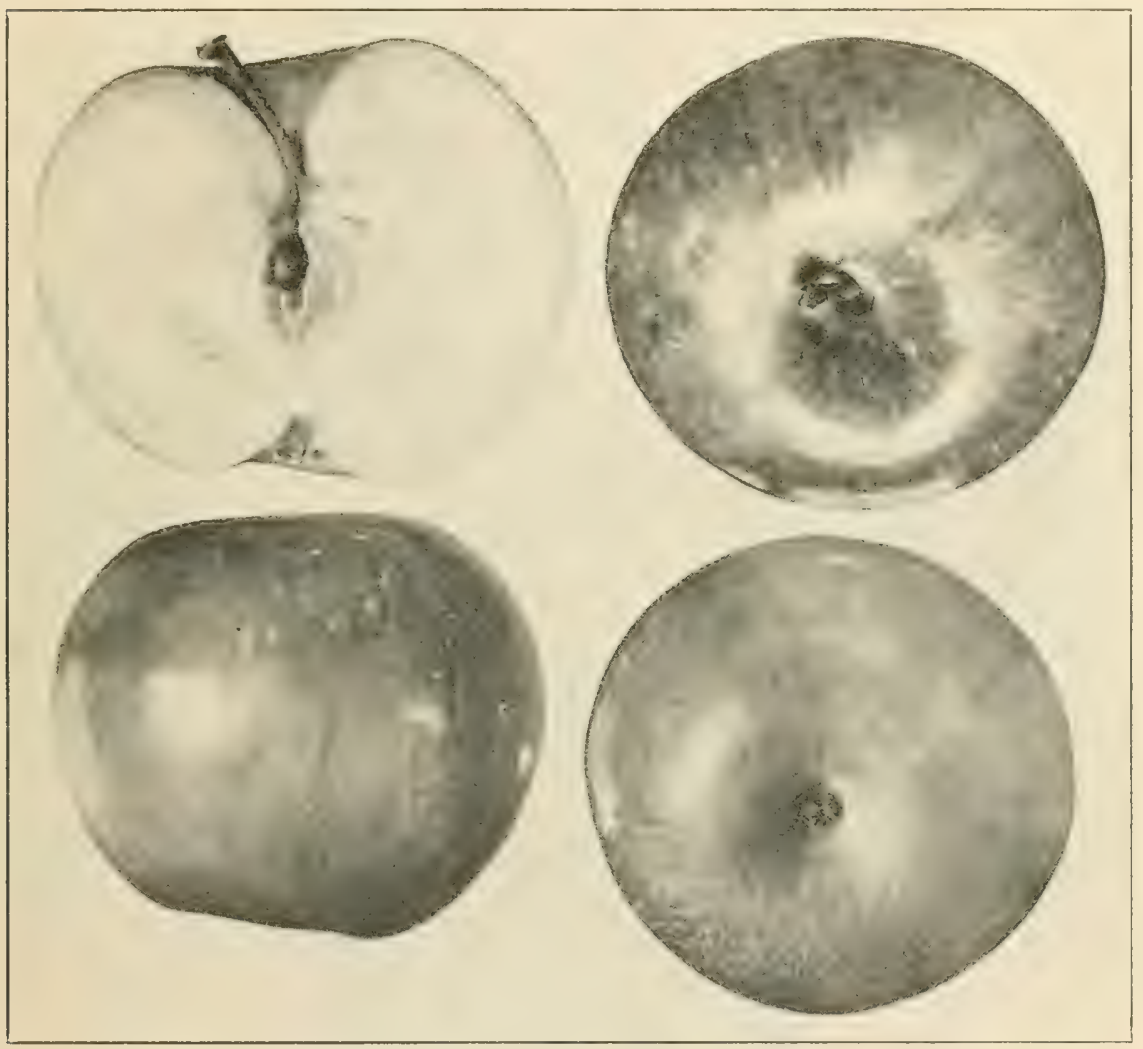

Fig. 10.-The Rome Beauty. (Original)

of growth, unless on very favorable soils. They rome into bearing carly and are usually heary and consistent producers. Because of a

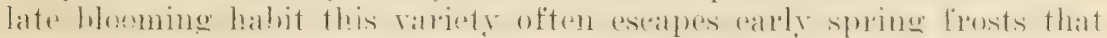
mean disaster to those varieties that bloom earlier. For this reason it

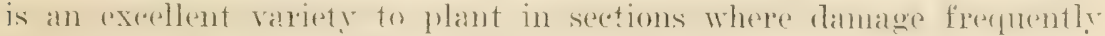
takes plater from such frosts. Trees are guite suseeptible to the attack of woolly aphis, green apple aphis and other species which affect apple trees. 
Sime of the finest spereinens of this varedy that the writer has ever seen came from the Yuratipal secetion of san Burnardino County. There are several orehards in this seretion at an elevation of about five thomsand feet where Rome Beanties are grown. Mr. Geo. Rowe of Grand Rapids. Mirhigan, who has heem hrad judge of the Califormia apple show each season since its oreanization. has seen spereinems of the variety from this secotion and considers them to be extra fine. ('oming from an

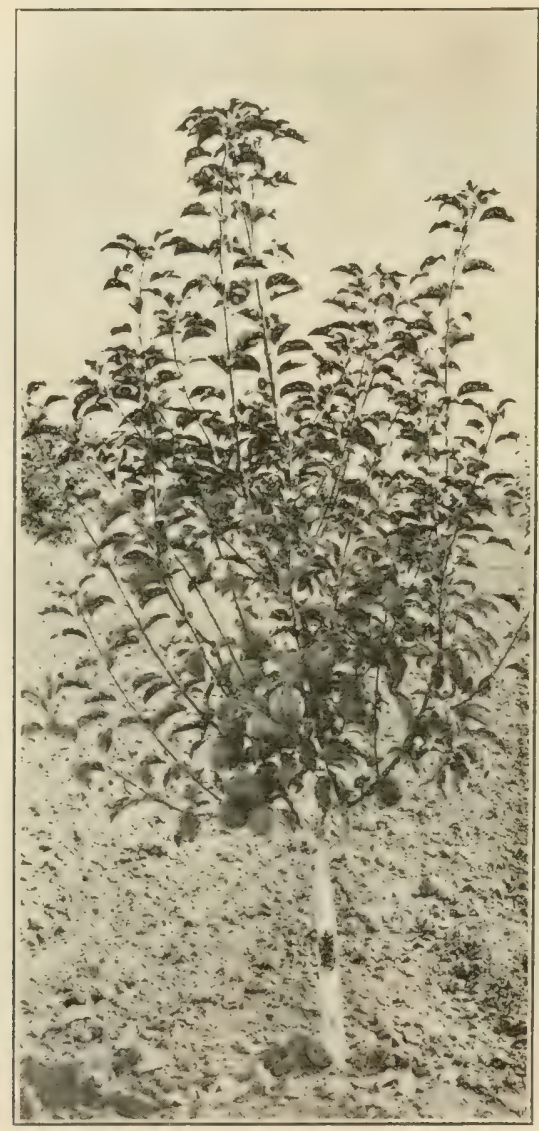

Fig. 11.-Young Rome Beauty tree with heavy load of fruit; Yucaipa, San Bernardino County. (Original)

anthority on apples such as he is, this information should mean something to the people of the Yucaipa district.

Figure 11 is of a young Rome Beauty tree on the E. N. Boyd place near Yucaipa, which illustrates the heary bearing tendeney as well as the young age at which they come into bearing.

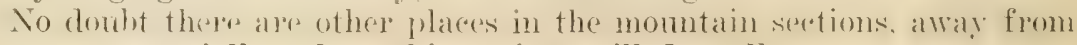
the coast especially, where this variety will do well. 


\section{RHODE ISLAND GREENING.}

This old New England varioty has heen found doing well in Tlumboldt ('ounty, and again in the extreme southeren part of the state in sian Diexo ('omenty. The (puality of this apple is good and it kexps well in storage.

The trees are strong and vigorous and are sermingly productive where grown in the state.

\section{ESOPUS.}

This excellent apple has not heen known to reatele the high dearees of perfection in California that it cloes in the Northwest, although it does pretty well in some places. The good kerping pralities and excel-

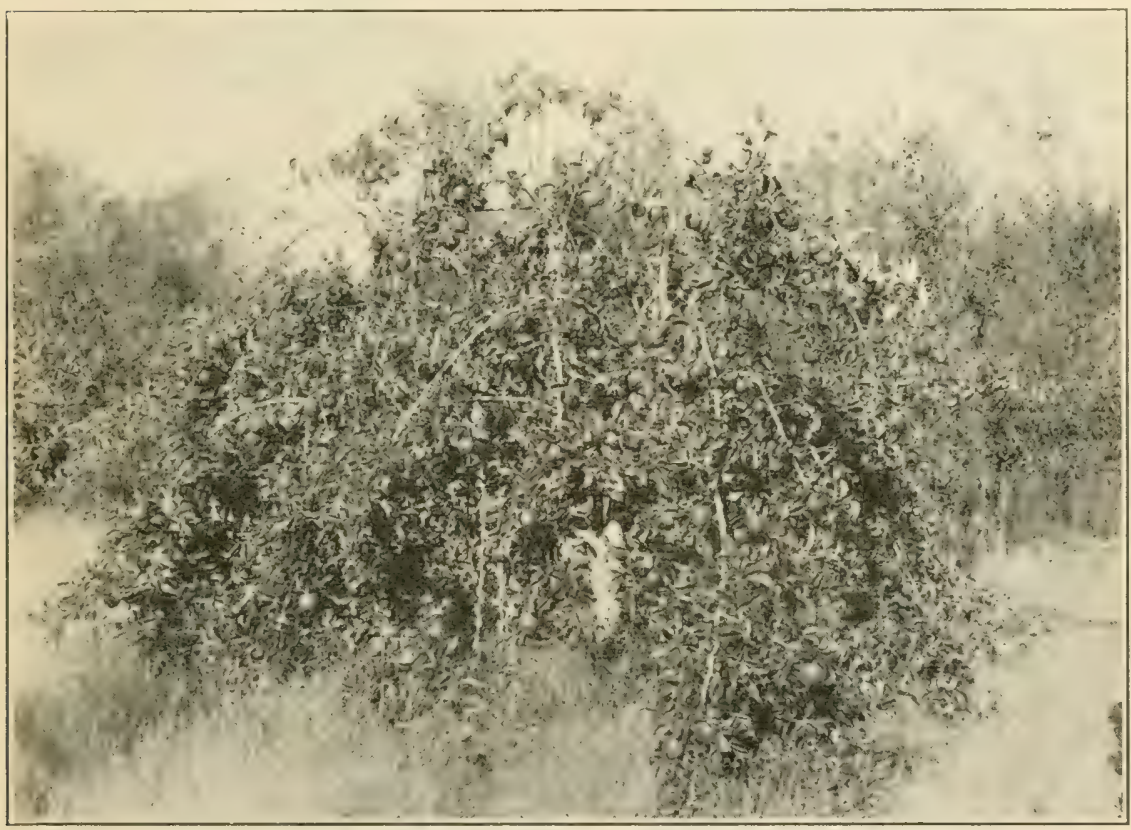

Fig. 12.-Stayman Winesap tree bearing heavily in Tehama County. (Photograph by C. B. Weeks)

lence in general commend it to a sreat many people and it finds a ready sale in our markets.

In California it is generally subject to seah and aphis, the trees themselves being moderately healthy. There are a few people in the state who will recommend it, and there may be some farorahle localities where it will do well.

\section{STAYMAN WINESAP.}

'The Stayman is a seedling of the old Winesal), which attains a greatere size, hut not quite such a good rolor. The quality is probably a little inferior to that of its parent. 'The kesping qualities of the two are about equal. both being in season about .January first and lasting

sipitzenluers. 
thromgh the winter. At present it is not grown extensively. but is a very promising variety. especially in the apple sertions of Sin Bernardino, Tehama and Riverside eounties. Figure 12 shows a tree in Tehamal County bearing heavily.

The trees are usually at thrifty as the regular. Winesap. It has been rated as a light bearer'. but may not be under ('alifornial conditions.

WAGENER.

Some splendid apples of this variety have been seen in Humboldt ('omnty, and the northern commties to the sonth, viz: Mendocino. Sonoma

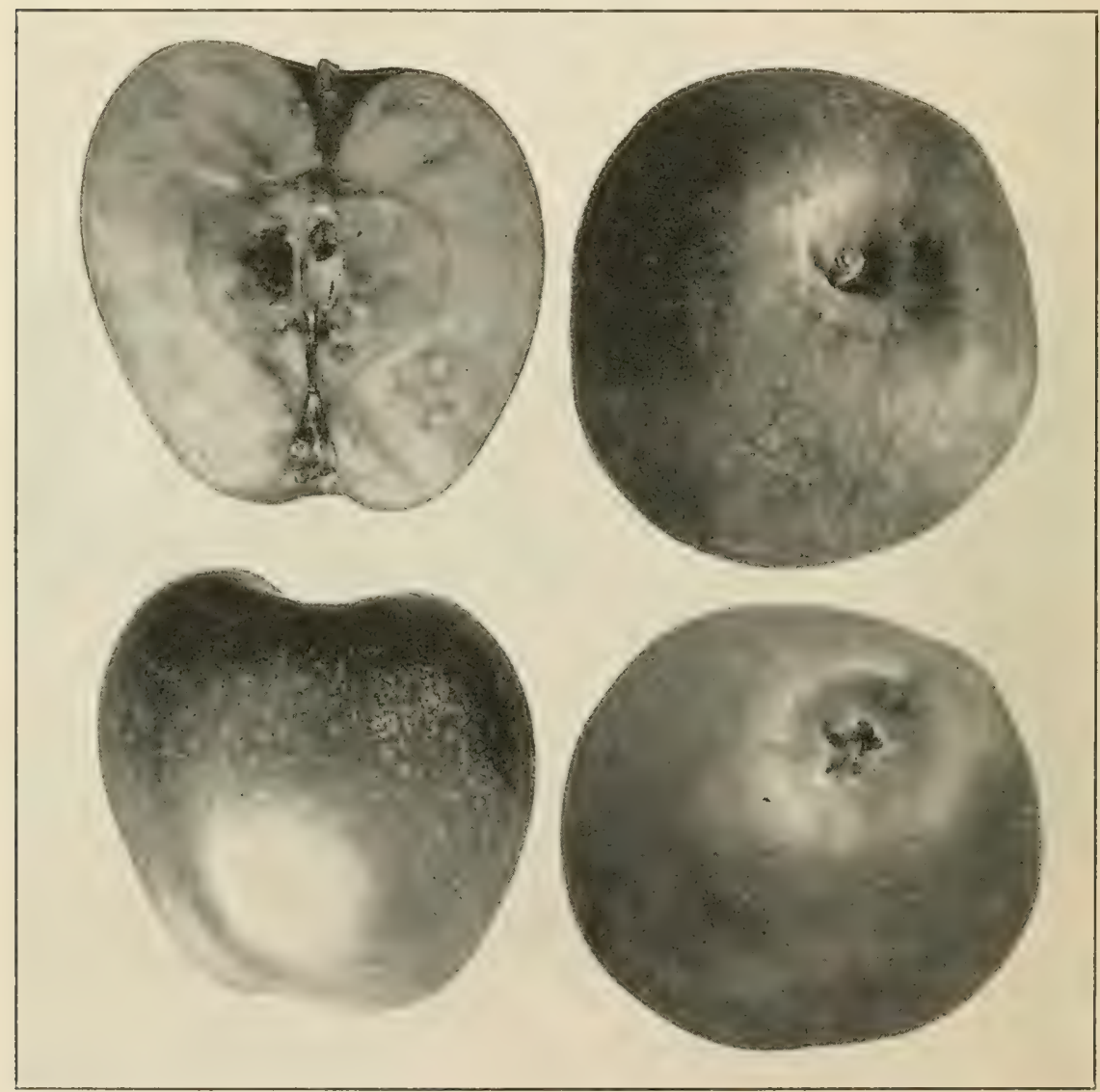

Fig. 13.-The Winter Pearmain. (Original)

and Napa, also seem to be weell adapted to its expowth and development. At its best it is a nicely colored apple of excellent quality and sells for a good price. It is rather early and does not keep well, but should be consumed before the holidays.

The trees are small but heavy bearers. This variety, probably more than any othere, has been used as a fillere in orehards of other varieties. It is anite subject to the blight in some localities. and is not ronsidered to be a long lived tree. 


\section{WINTER PEARMAIN.}

(Fig. 13.)

Among the list of green colored varieties there are for of bratter quality than the Winter Pearmain. This variety has been quite exteusively planted in the past in California and there are few of the older orchards where it ean not be found. It is a good keeper and during the holiday season is in its prime, though it keeps well for a long time afterward. On some of the lighter soils quite a little color is produced,

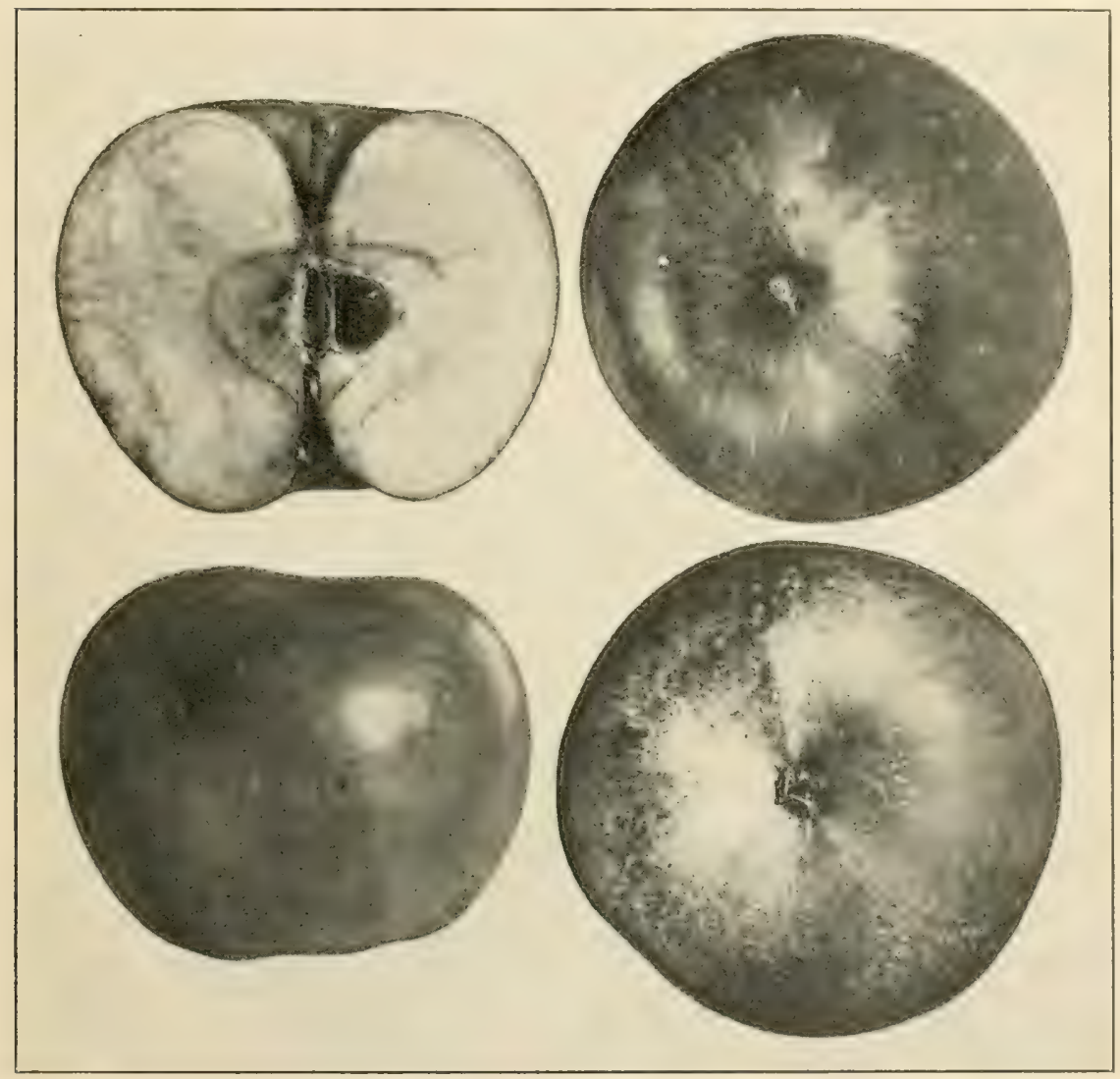

Fig. 14.-The TVinesap. (Original)

thus adding to its attractiveness and selling qualities. This apple, if it had a red skin, would be much more popular.

The trees are exceedingly productive in this state, in some places bearing crops almost annually. If the soil is at all suitable good growth takes place, and if pruning and thinning are practiced consistently gond fruit of uniform size and quality can be expected.

There are few places where the writer has been that this variety has not been found doing well. In the mountainous sections of Madera, San Bernardino and San Diego comnties some excellent specimens have heen seen, and in the Pajaro and Santa Clara valleys it has been grown, not extensively, but always with uniformly good results. ('onsequently it is recommended for use in practically all the apple growing sections. 


\section{WINESAP.}

( Fig. 14.)

One of our most cosmopolitan. as well as generally popular varieties of apple. is the Winesap. While it is inclined to be small the quality is erood, the red color such as to attract attention. and the kerping cualities of the best. It is an excellent winter variety for general use, and when at its best commands a ligh price. There are few of the older orehards in Califormia where this variety is not found, and it has been ruite "xtensively planted in the foothills sections. Some remarkably fine sperimens have heen taken in the Sierla Nevada mountains at an elevation of about five thousand feet.

The trees are inclined to grow bushy and ordinarily reapuile heary pruming. This applies to old as well as young trees. Not only is heary pruning necessary to keep the trees in good shape, hut also to induce the apples to attain a good size. The tendency is alvays for them to be surall on older trees, unless pruning is properly done.

In the coast counties at low elevations this variety is not commonly planted. and is only recommended for the interior foothils and momntain sections.

\section{BANANA."}

The brautiful blush of this variety has made it a favorite for planting in some sections. Tike the ()rtey and frimes it is rather delicate and must be handled with great are in pieking and parking. It usmally does best at pather high altitures, although some beatiful specimens which were grown in Santa ('ruz Comnty were exhibited at the jecent (alifornia Apple Show. Some fine fruit is produed in Modoe County.

While a fairly good keepere ordinarily. it is at its best rather early in the season.

The trees are vigorous when young, at least, but are inclined to be rather stunted later, unless grown muler the most favorable conditions.

\section{YELLOW BELLFLOWER.}

(Fig. 15.)

Probably nowhere else has the above variety been grown so extensively and reached such perfection as in the Pajaro Valley of this state. or what is better known as the Watsonville section, which includes parts of santa Cruz and Monterey comnties. The difficulty experienced in getting red varieties to color well in this section is no doubt responsible for the extensive planting to this rariety and also the "ommonly grown Yallow Newtown, another light rolored apple. When grown on favorahles soil and when not pirked too (arly it develops a blush that makes it very attractive. It keeps well until after the holidays and is a general favorite in California for the early market.

The trees grow very larese and sturdy and in California beal quite regularly and their size aftere they reach the age of tifteen years or more. makes it possible for them to bear some very laree "rops. In most parts of the country it is rated as a light bearer.

\footnotetext{
${ }^{4}$ Vinter Banana.
} 


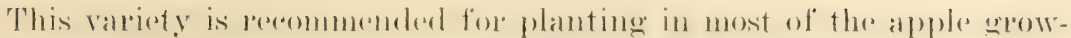
ing seretions of the state, as it may be foumd doing well at high elevations, as well as places near sea level. Because of the fact that Watsonville has made a speceialty of this valdety it would probably not be wood business julgment for oflex serotions to plant it axtensively, hut it would be better for them to choose some variety known to do well under their ronditions.

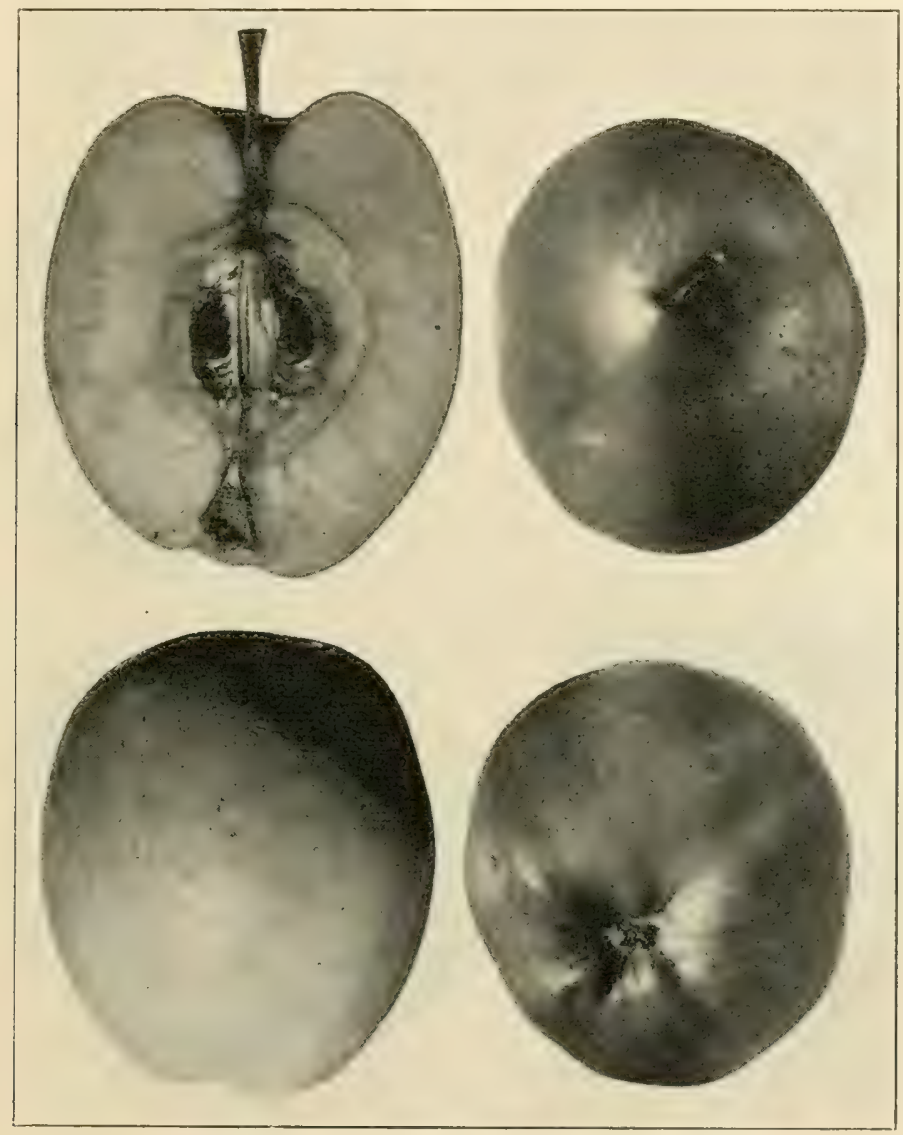

Fig. 15.-The Yellow Bellflower. (Original)

\section{YELLOW NEWTOWN.}

(Fig. 16.)

Like the Yellow Bellflower this rariety is exceptionally well adapted to the conditions of soil and dimate of the Pajaro Valley, and there reaches a high degree of perfection. These two varieties constitute by far the greater part of the arerage (about eighty per cent) planted to apples in that section. The Yellow Newtown ripens a little later than the Yellow Bellfower, is firmer and a better keeper. It is quite a 
popular variety for the export trade as well as for general use. In (alifornia it is (quite subject to mildew and seab and these diseases often play havoe with the trees and fruit where nothing is done to control them. Bearing begins reasonably early and good crops are the rule in the state.

The trees are quite large and thrifty but do not usually attain the size of the Yellow Bellflower.

There are few localities where this variety does not do well, and like the Yellow Bellflower it is recommended for planting in all apple sec-

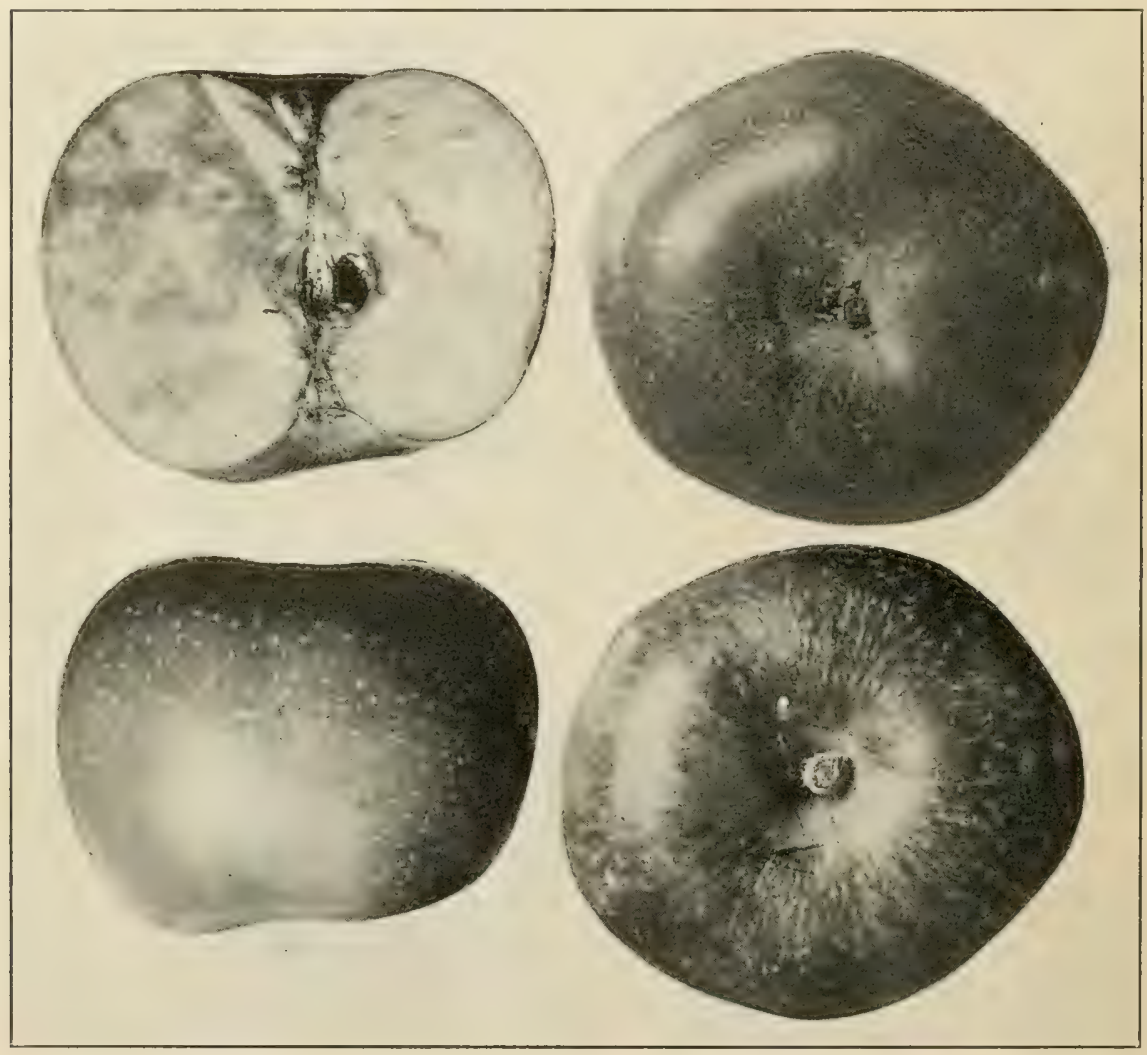

Fig. 16. -The Yellow Newtown. (Original)

tions of the state where a good light colored apple is desired. In IHumboldt and Lassen counties in the north and in San Diego, Riverside and San Bernardino counties in the south fine specimens have been collected.

The trees will stand very heavy pruning, which becomes a necessity in sections where mildew is bad, as one of the best ways to control this disease is by pruning out infested twigs as they appear. 


\section{PROPAGATION OF THE APPLE.}

The work of propagating alple trees is usually loft to the murseryman, although there is no good reason why the person who is contentplating the setting ont of an orehard should not propagate his own tres.

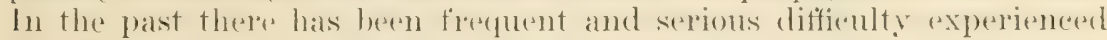
by the purchaser of nursery trees because of not receiving varieties ordered. The nurserymen of today, as a whole, exercise the greatest care toward sending out trees true to name, so the one-time serious objection to buying trees from them has been laregely removed. It is true, howerer. that many nurserymen are not careful enough in the selection of the stork used for budding or grateing purposes, and as a ronsecfuence trees may not he inherently strong. The future will no

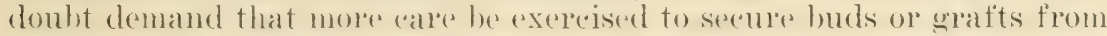
trees that have a record of good crop production to transmit, or at least which they will surely have a tendency to transmit to trees developed from them.

\section{SEEDLINGS.}

It is known by practically arery one that the apple. when grom from sered, does not come true to the variety. That is, if a thousand trees weres grown from seeds taken from a siugle .Jonathan apple trese there would probably be none of them that would possess many of the characteristies of the true. Jomathan. This fact neerssitates the propagation of the apple hy hudding or errating of fixed varieties into seedlings grown for the purpose. 'The first ster), thene, in developing trees for an oreharel is the growing of seedlings.

Wickson recommends the following method of starting apple and pear trees from seed:

For a small lot of apple and pear trees the seed can be best sown in boxes. Select plump pips and keep in moist sand from the time they are taken from the fruit until sowing. Fill the boxes, which should be three or four inches deep, with good garden mold, cover the sect about half an inch, and then cover the soil lightly with chaff or fine straw to prevent the surface from drying out. Be sure that the boxes have cracks or holes in the bottom for drainage, and the whole is kept moist. but not wet. When the seedlings have grown to the height of three inches they can be set out in the nursery rows, as one would set out cabbage plants.

After these seredling treses have attained sufficiont growth they may be budded to whatever varieties are desired.

seeds for use in growing trees should he selenterl form good stork, if possible. Small, shrunken sexd from poor apples is no more desirable than poor stock for hudding purposes, as the thriftiness of the seedling tree will very largely detromine the development and growth of the bud or graft that is inserted into it. Seeds are usually olitained from thr pomace of cider mills. As such seeds from our Amerinan mills ordinarily possess nothing of uniformity in their makeup, a good stand of thrifty seedlings can scarrely be expected when grown from them. The lest sexpllings atre those grown from the wild crabs of trance and most 
of our nurserymen make a practice of buying either seedlings or seed from this French stork, which appears to have little value except for cider and seeds.

\section{BUDDING.}

The budded apple tree is now generally preferred to the root grafted tree. The operation of budding is really more simple than grafting, the union of hud with stock is usually better than in the case of the Eraft, and the trees are believed to be less liable to attack by crown gall. For these as well as other reasons propagation by budding is praceticed by most of our best nurserymen.

Budding can best be done in ('alifornia in August and September', in which case the inserted bud mites with the seedling stem and remains
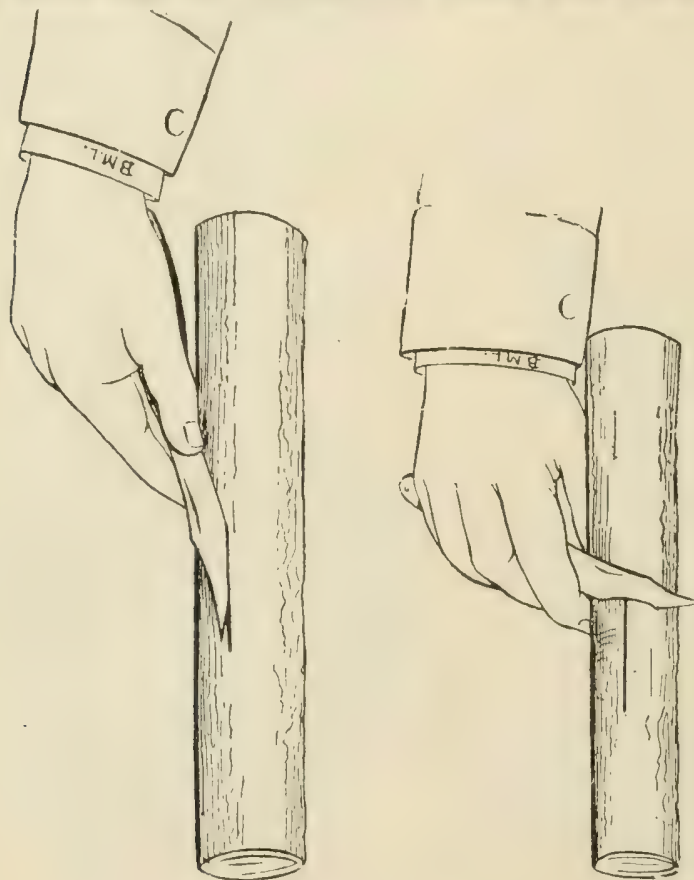

Fig. 17.--"Preparing the stock to receive the bud."

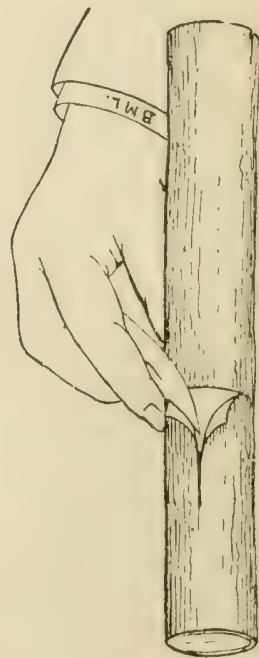

(After Lelong)

dormant throughout the winter season, making no growth until the spring. At this time the top of the tree should be removed, cutting just above the bud. The well established root system of the seedling will feed the new bud abundantly, and a rapid growth should take place, developing a satisfactory size of top for planting in one season.

Bud wood should be selected from bearing trees which have produced satisfactory erops, and only strong, healthy buds should be used. The practice of using bud sticks from young trees which have never horne. because of the convenience of securing them at the time of pruning, cannot result in the development of the best kind of unrsery stock. In practically every orchard there are certain trees that have produced big erops of fruit year after year with searcely a failure, while the average trees have not done nearly so well. Such heary producing 


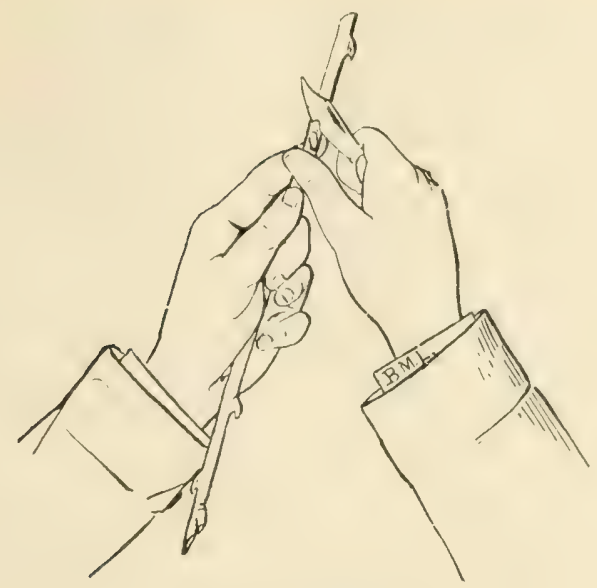

Fig. 18. "Cutting the buds from the scion." (After Lelong)
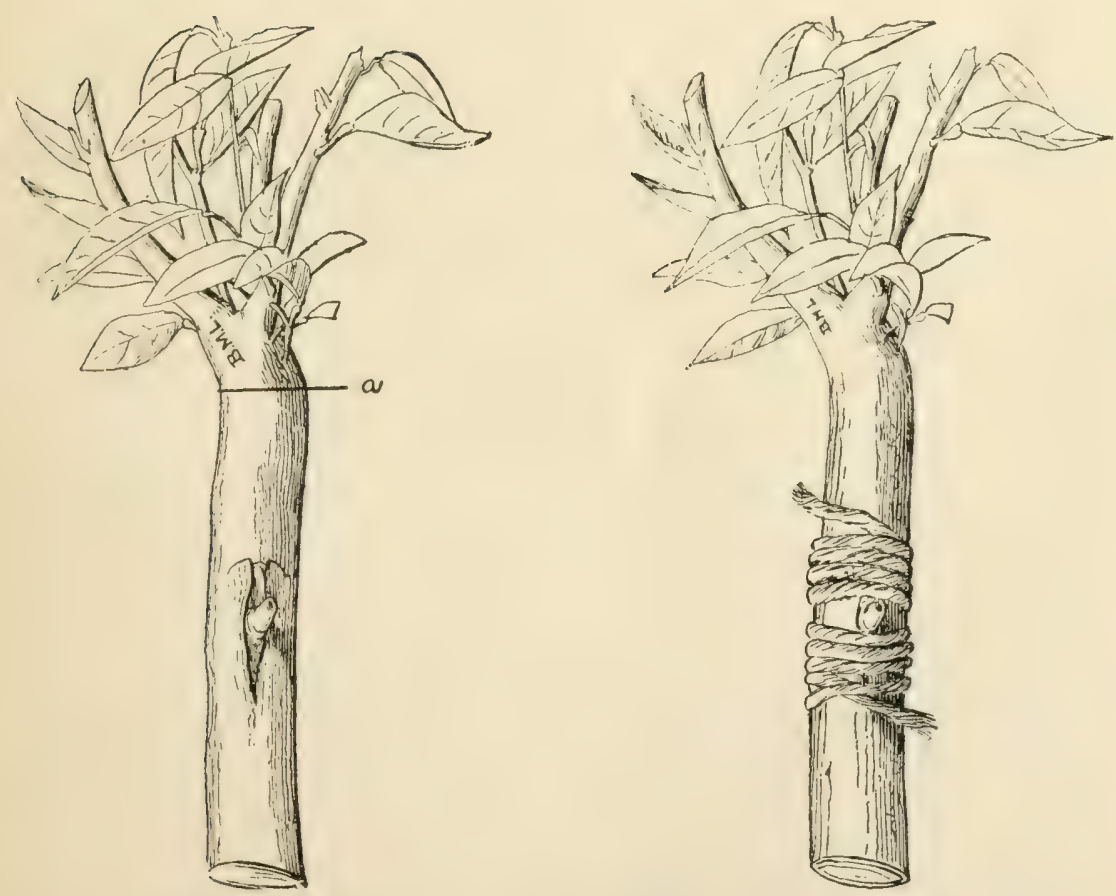

Fig. 19. - "Showing bud inserted and the wrappings. In some cases a few limbs are left to promote vigor." (After Lelong) 
Irees, other "haracteristies being desirable also, should be the ones from which buds are taken. The orchardist usually has a better chance to utilize such trees than the nurseryman. The limited number of trees that he would need for his own use often makes it possible for him to secure bud wood from only one tree, which possesses more desirable (characteristies of its kind than any other with which he is familiar. The wide breach between the quantity of fruit represented by the maximum producing trees of an orchard and the minimum, or even average producer's, can never be yreatly lessened until more eareful attention is given to the selection of buds for propagating purposes.

The budding operation is quite simple and is well illustrated in Figs. 17, 18 and 19, after Lelong. These illustrations were made for use in a citrus publication, but as the operation with apples is similar, they serve the purpose in this book equally as well.

In the nursery an expert budder merely inserts the buds, the tying being done by some one else who immediately follows him. Either rotton twine or fibre from palm leaves. known as raffia, is used for holding the buds in place. As much care, if not more, is necessary in the tying of the bud as in placing it beneath the bark. The tying should he tightly done, thus binding the hud firmly to the stem and greatly facilitating its starting.

\section{ROOT-GRAFTING.}

This operation is accomplished by the use of seedling roots, whole or in part, to which bud wood of the desired variety is united. In the past this has been a very popular method of propagating nursery apple trees. but has been very largely superseded by budding, for reasons already given. Such grafts are usually made during the dormant season, and kept in wet sand or other suitahle material until setting time in the spring. 


\section{SELECTION OF TREES FOR PLANTING.}

Which varieties are selected should depend, first. uyon their adaptation to the conditions existing where they are to be planted, and. secondly, upon whether they ale to be used for commercial purposes or for a home orehard. If the orchind is planted for commercial reasonsand that is really all that need concern us in this article-only a rely few varieties should be secured. What these shall he should be determined by careful observations of profitable trees in nearby orchards in a section, if older orchards can he found where information is easily ohtainable; if not. similar conditions elsewhere may serve as a guide. but in this case the value of whaterer varieties are planted will have to be laregely determined by experiment. Every older apple section las passed through this experimental period, and, as a consequence, we find in our state many old orchards of a miscellaneous lot of rarieties. some good aud some bad. Such orchards very often do not have enough good trees in them to justify their existence on the ground they ocempy. It is always a good plan to go slow with the testing out of new varieties. The nursery arent who understands his business as a salesman very often has no trouble in persuading people to buy varieties that, while they may be good, have never been tried out in the section, and should not form the major part of a new orchard. To test them out in a small way by planting only a few, until they are known to do well, is a commendable thing. Practically every apple section of any consequence in California has growing in it some well adapted varieties that have produced fine crops year after year. A few of such varieties, preferably not more than three, should be selected hy the prospective grower. Suecess will come to a section when it can produce, in quantities, some variety or some few varieties of prime frut better than any other secfion can produce them. An illustration of this may be found in the fine Cravensteins of the Sebastopol section of Sonoma County, or the Yellow Bellflowers or Yellow Newtoms of the Watsonville section of Santa Cruz County. With a miscellaneous lot of varieties, and no great quantity of any one, these famous apple regions would never have gained their reputation. In the mountainous parts of the state, especially that portion oceupied by the Sierra Nevada rauge, may be found a great many other equally good varieties, such as Jonathan, Rome Beauty, Esopus, Winesap, Delicious, Winter Pearmain, Baldwiu, Northern Spy, Taiden Blush and Ortley, any one of which, if grown extensively and handled well, should make a reputation for its section, as the previously mentioned varieties have done for Sebastopol and Watsonville.

Some varieties are more or less self-sterile, and mnless interplanted with other varieties as pollinizer's they may fail to produce well, if at all. With the limited amount of scientifically accurate work that has been done along this line, it is impossible to say just which varieties are selffertile and will do well when planted alone. It is sate to say that large blocks of any rariety should not be planted, for even though they may be self-fertile the effect of cross-pollination would undoubtedly be good. 
The following table, prepared and published by Frederick Maskew, shows the wide variation in time of blooming of a number of different varieties, something which should be taken into consideration when selecting two or more with the idea of getting the best results in crosspollination.

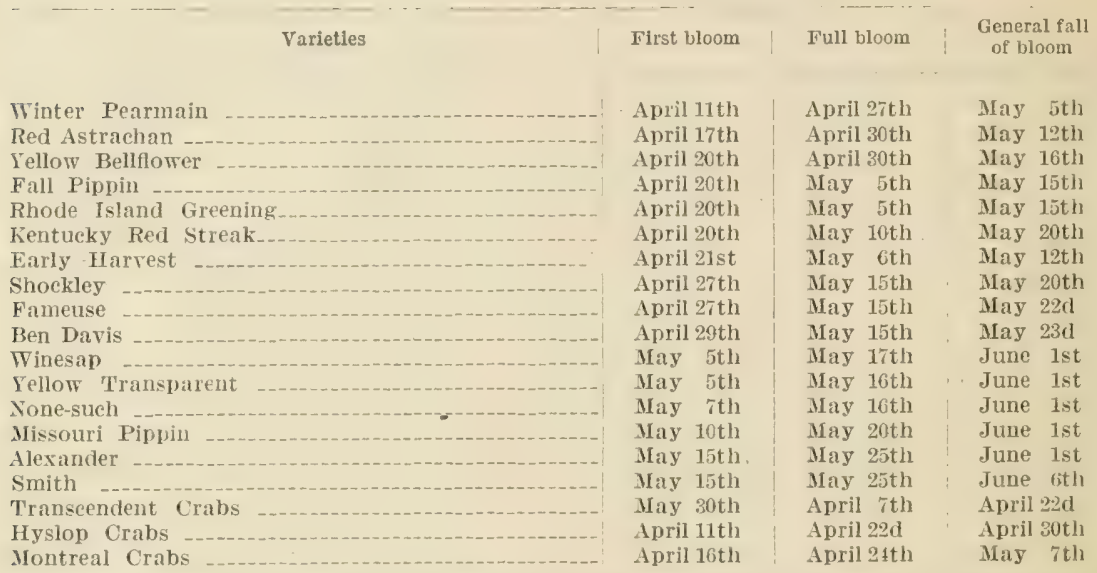

\section{DEMAND THE BEST.}

Inving selected suitable varieties only the best trees should be considered for planting. Generally speaking. a cheap tree is a poor tree. In any nursery there are a certain number of trees which have never made a good growth and which on being dug are sorted out as low grade trees and sold for a lower figure than those which have been thrifty. Frequently these stunted trees never develop into first-class treess, no matter how great eare they may receive. Trees possess an individuality which must be taken into consideration. Often being grown from buds selected miscellaneously, it is to be expected that there will be considerable variation in their size, hardiness and habits of growth. While it may be possible to build a fairly good tree from one which possesses nuany mondesirable characteristics, yet it is much safer to choose the rery best, which are likely to be inherently strong, and which will consequently respond readily to good treatment.

\section{AGE OF TREE TO PLANT.}

All things considered, the best apple tree to buy is the one year old whip. Such a tree has a three year old root system-- two years' growth as a seedling, and the third as a budder tree. Thus the top is only one year of age when the roots are three, and all the plant food which they take up is utilized in developing this one year old top, which normally makes a thrifty and healthy growth with little or no branching. When set, trees of this kind should throw out branches in abundance throughout the entire length of the trunk, a very desirable thing, as a certain type of head being wanted there will be no trouble in selecting branches to conform to that type, and uniformity may be attained in the

sApple culture in Los Angeles County. 
heading of an orchard. In the case of the two year old tree it is usually headed a certain height in the mursery row, generally higher than is desirable for the orchard tree, and uniformity of heading is exceedingly difficult to secure. Sometimes such trees when set are denuded of brauches, a mere whip being left. but when this is done they do not make as much lateral growth as the one year old tree, and it may be rery difficult to select branches of the right height and properly spaced for the best type of head.

\section{FREEDOM FROM DISEASE AND INSECT PESTS.}

Thanks to the very areful inspection work in California, under the direction of the county horticultural commissioners, trees are usually quite free from recognizalle diseases and insect pests, when they are set. Trees infested with such diseases as erown gall and such insect pests as woolly aphis are seldom planted. Our inspection system. while far from being perfect, has not only been sureessful in the detection of disease and inseet pests. hut it has also resulted in ereater care heing exeredised by the grower of numery trees. that the be wean. It is not always possible for the inspector to detect erown gall in its first stages, but the fact that he is always looking for it and destroying trees mpon which it is fomnd. has made the nurseryman realize his obligation relative to this tronble. and as a ronseduence trees are not wrown on land after it becomes thoroughly infereded with the disease. as they were at one time. This illustration is one of many which might be given to show that the tendency nowadays is toward better stock, as far as insect pests and diseases are concerned. It is of the utmost importance for new sections to plant clean trees, as by so doing many yars may elapse before some of the very ammon tronhles will find their way into orchards of the section.

The very great distribution of the woolly aphis is no dould due largely to the fact that it has been planted with the nursery tree. With our moderu methods of inspeetion and fumigation the chancess of living aphids being on the roots when trees are set may and should he reduced to the minimum. Preventive measures of a simple nature may mean freedom from such pests for rears, and consequent liealthiness of trees, while inattention to such mar mean large sums of money and much time expended in spraying, ete., with the result of possible control by a diminution of the pest, but never eradication.

The inspertion work to secure this freedom from insects and disease shonld receive the encouragement of every one interested in fruit growing, not merely hecause the inspector may he able to detect pests, but also hecause of the fact that his efforts will mean a greater effort on the part of the nurseryman, which, after all, means more than the inspection after the stock is grown. There are places, to the writer's knowledge, where inspection work is not done. which have been made dumping grounds by unreliahle nurserymen for their undesirahle stock. 


\section{SOILS AND THEIR PREPARATION FOR PLANTING.}

Apple trees require good, deep, well drained soils, preferably of a somewhat light clayey loam. No definite rule can be laid down as to the particular kind of soil for them. Many splendid orchards may be found growing on light, sandy river bottom soils, while others have done equally as well on quite heavy clay, even of the type which we speak of as adobe. Generally speaking, however, the very heavy and very light soils should be avoided. In California the brown or red mesa soils of the foothill sections along the Sierras, where they possess sufficient depth, grow fine trees. Back in the mountains proper, at high altitudes may be found a black loam, very moist and full of humus, which is admirably adapted to the growth of apples. The coast section, including Santa Cruz and Sonoma counties, has a variety of soils, ranging from light sand to stiff clay, and a number of types are known to produce excellent trees and fruit. Poor soils of any kind are not good for apples, and trees should never he set out on land which is too poor for other crops. IIardpan lands should be avoided. A layer of gypsum. marl, or heary clay within three feet of the surface is not desirable: neither should soils be chosen where water stands within three feet of the surface at any time during the season. In such eases alkalies are very apt to become bad. While trees may grow fairly well for a number of years with hardpan or water close to the surface, sooner or later they are sure to show signs of trouble. This may manifest itself as small, yellow, sickly foliage. sparse growth, or as a mass of foliage toward tips of twigs, or some other condition indicating starvation. The healthiest trees, generally speaking. are those which root the deepest, and all conditions unfavorable to derep rooting should be avoided as inuch as possible.

Varieties developed to perfection on a certain type of soil would naturally be expected to do best on similar soils elsewhere. This is a phase of the question that has not heen given much attention in the past, but one which no doubt will receive more consideration in the future. Prof. J. W. Nelson of the University of California, in an address before the State Fruit Growers' ('onvention at Davis. in .June, 1914, on the "Fruit Soils of the Great Interior Valley," touched upon this subject and gave some striking illustrations of the truth that varieties do best on similar soils in different sertions and made the following statement: "In our studies in this state, and elsewhere in the United States, we have observed that each kind of fruit, like other crops, has a soil and elimatic environment in which it reaches its greatest perfection, and when grown on a type differing greatly from that to which the variety had adjusted its functions of growth. failure frequently results and one or more of the essential qualities is missing or is replaced by other inferior or superior ones. So if we have a desirable variety, possessing qualities which we wish to retain, we must grow the variety in a soil and climate like or nearly like those in which it oltained its 
desirable qualities." This is illustrated nicely by Mr. Nelson, in the case of certain varieties of strawberries grown in Delaware, in the following words :

"Two soil types were present, namely: the Norfolk sandy loam and the Portsmouth sandy loam. The former is a well drained brown soil. moderate to low in humus, quickly warmed up in springtime, and oecupies a position from one to several feet higher than the latter. 'The Portsmouth sandy loam is a low, damp, cool. black soil, very high in humus. The Gandy berry thrives and develops musually desirable qualities on this soil. but becomes a miserable failure on the Norfolk soil. The Parson's Beauty, Chesapeake, and one or two other varieties reach great perfection on the well drained, warm, moderately fertile Norfolk soil, but fail on the low, damp, cool Portsmouth type.

"Farmers did not know the cause for this and kept on trying to grow the Gandy, a most attractive market variety, on the Norfolk sandy loam and thousands of dollars were lost every year for years in this attempt alone. After a careful observation of the soils present it was decided to trace out the origin of the Gandy variety and see, if possible, why it was so partial to a certain kind of soil and so sensitive to others. After some time the variety was traeed to New Jersey, and it was discovered that the first seedling had originated on the same type of soil on which it was thriving in Delaware."

This striking illustration will no doubt apply to apples equally as well as to strawberries.

\section{PREVIOUS CROPPING.}

Many fine orchards are growing on soil which was virgin at the time they were planted. It is equally true that many failures may he traced to lack of preparation of the soil for trees. It is safe to say that "ropping previons to setting trees in order to better prepare the eround is always best. There is no better crop to grow previous to planting trees than alfalfi. Onr arid. western soils are usually low in nitrogen. which may be supplied in abundance by alfalfa. This crop. hecause of its root system, prepares the soil for tree roots hetter. probably, than anything else that ran be grown. Trees set on alfalfa ground vismally make a very quick and healthy growth. The writer has sometimes advised the eroppinge of land in alfalfa for a eouple of years before planting apples, rather than gain two years in the growth of trees bs putting out the orrehard at once. The gain in time may be completely compensated for in a few years by the extra crowth and productiveness of the trees following alfalfa. Other legmmes. 1. ./. peas, heans, vetehes and the clovers may he nsed to advantage in preparing the soil for trees. but none of these possess the merits of the deeply raoted alfalfa.

\section{LEVELING.}

Many an orchardist has experienced much difforulty in irrigating his orchard, because of inattention to leveling the land before the trees were planted. A seraper is very often necessary for use in rutting down high places and filling in low. When the land has been made approximately level by the use of the scraper, it should be dragged or leveled by means of a common frame, field drag or some other suitable 
implement made for the purpose. After the leveling is done harrowing to break up all elods should not be neglected. Noisture may be conserved much better if a fine dust mulch ean be made on the surface of the soil, and a disc harrow, cultivator, common harrow or any other implement which will best make the mulch should be used. It should be remembered that a smooth surface such as might be secured by rolling the soil will lose moisture much more quickly than a surface broken up by the harrow or other eultivating tool.

\section{PLOWING.}

It seems hardly necessary to say that ground should always be well plowed before trees are set out, for nearly every one realizes the importance of this operation. It has already been said that a deep root system is advantageous, and for this reason, if for no other, soil should be plowed deeply to better insure such deep rooting. Not only should this deep plowing be practiced previous to setting the trees, but frequently afterwards. In general it may be said that an orehard should be plowed once a rear and always to a good depth, so that the soil may be loosened sufficiently to induce deep rooting of the trees. Plowing in preparation for planting is often very carelessly done because of the fact that holes of a considerable size and depth are dug for the trees and it is not considered that eareful plowing is necessary. In our arid sections where the rainfall is light-where there may be little or no water for irrigation during the dry season and as a consecquence it is necessary to conserve all the moisture possible-the plowing operation should never be slighted in any way.

\section{HOW TO DETERMINE NUMBERS OF TREES PER ACRE.}

Any one desiring to find out how many trees cam be planted per acee, at given distances apart, can do so by multiplying these distances in feet and dividing 43,560, which is the number of square feet in an acre by the product. For example. it is desired to plant an orehard on the square 30 by 30 feet; the product of these two distances is 900 , and 43,560 divided by 900 equals 48 , the number of trees that ean be planted per acre at this distance. If the hexagonal system of planting is to be used the number may be determined hy adding to this number fifteen per cent of itself. For example, 48 times .15 equals 7 plus, which added to 48 equals 55 plus. Similarly any other distances being known the number of trees per acre may be determined.

\section{SYSTEMS FOR PLANTING.}

The different systems for planting trees are well illustrated in the accompanying figures, numbers $20,21,22$ and 23 . There are four of them in all, and they are known as the square, triangular, quineunx and hexagonal methods. The first and last are generally used, the hexagonal having the advantage of allowing fifteen per cent more trees in a given area. A very common fault in the planting of our older apple orchards was the setting of too many trees per acre. Crowding, after a few years' growth, has as a consequence taken place, to the serious detriment of the crop and to the disadvantage of cultivation, picking and other orchard operations. Most varieties of apples should be 
APPLE GROWING IN CALIFORNIA.

41
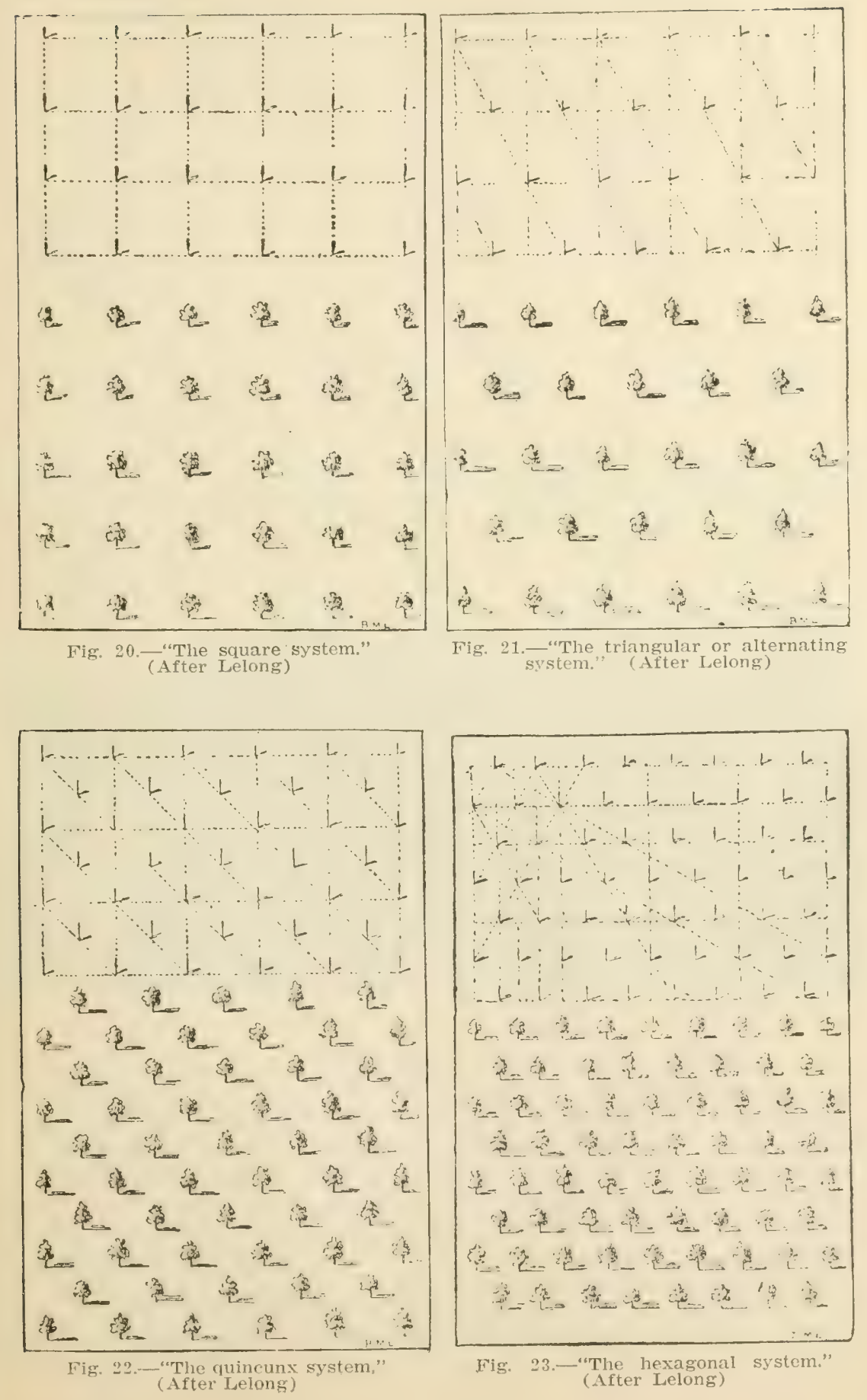

Fig. 23.- "The hexagonal system." 
planted about thirty feet apart. This distance gives ample room for all the work that must necessarily be done in the orchard, and if pruning is properly done there should never be any serious trouble from crowding. Fig. 24 is a young apple orchard at Tehachapi planted $30 \times 30$ square system, which has been well laid out. By setting this distance apart there would be forty-eight trees to the acre. If the hexagonal system were used there would be fifteen per cent more trees. or fifty-five to the acre, with no two trees closer together than thirty feet in this ease, the distance between the rows heing only twentysix feet. This method of setting is quite popular because of the extra number of trees that an be planted without erowding. It possesses the disadvantage of leaving less room between the rows for cultivating and hauling fruit.

\section{DIGGING HOLES.}

IIsles should be lanwe enough so that roots may be set with their natural spreat and not cerowded and twisted together into a small

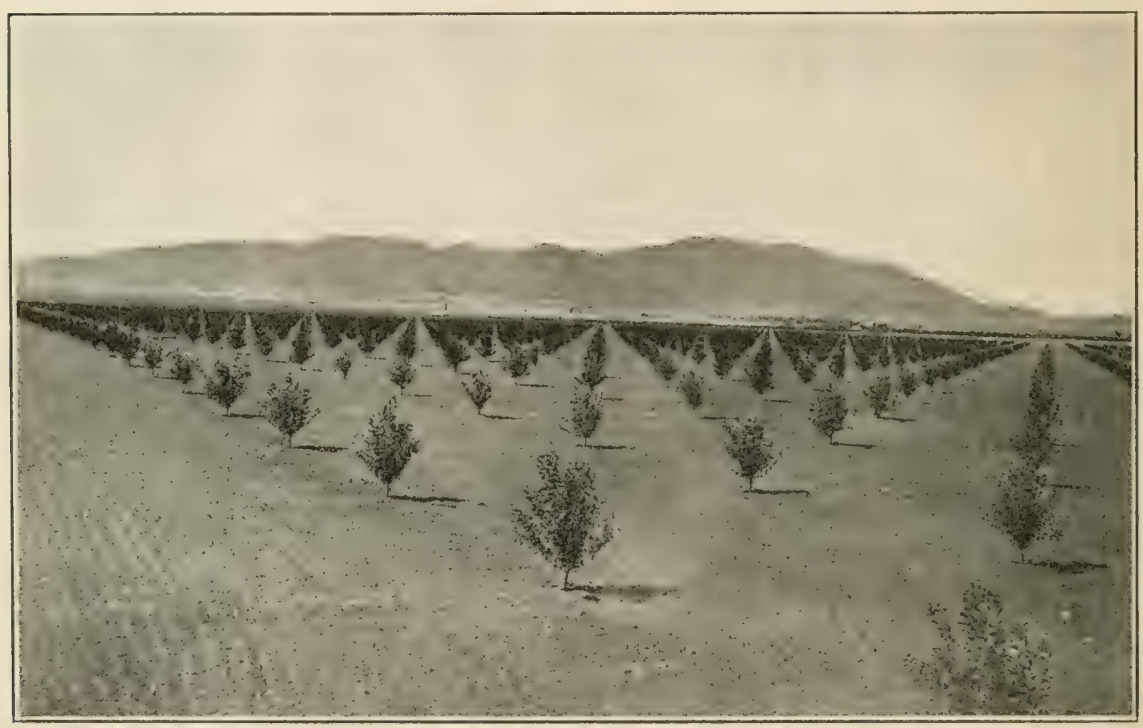

Fig. 24.-A young apple orchard at Tehachapi. (Original)

space. Sometimes the diffieulty of digging holes is respousible for such a condition of crowding, but trees had better not be set unless the root system ean have a fair show from the start. The soil at the bottom of the holes should be loosened to a considerable depth to facilitate deep rooting, and to enable the root system, which is always more or less damaged when taken from the nursery, to get a new start quickly.

It is now quite a general practice to use dynamite in loosening the soil, especially where hardpan exists. There is often much to be gained by its use, but care should bo exercised to avoid packing and the consequent defeat of the object for which it was employed. Dynamiting should only he done. in heary soils with a tendency to run together, at least, when they are dry. If moist there may be a packing or cementing, which is 
decidedly bad. The post bar and shovel may (o) the work as well as dynamite and are safer if the soil is wet.

\section{LAYING OUT LAND.}

The establishment of points for the sefting of trees may be conveniently done with a surveyor's level or transit. If such instruments are not available alecurate results may be attained by sighting to stakes with the eye. Difficulty sometimes arises because of irregularly shaped tracts, hut in such cases it is only necessary to establish straight lines as guides in laving out the main tract and filling in angular piecess afterwards. By estahlishing such lines a rectangular tract may be laid off, the boundaries of opposite sirles being marked by stakes of a convenient size and color so that they may be casily seen, and defining accurately the distance between the trees or rows. A line of stakes set the same distance apart should be rum parallel to one of these boundary lines somewhere near the middle of the field. These three being determined, points in between to locate position of trees can be accurately placed also, and by sighting in two directions at right angles to each other, theie should be little chance of serious errors in aligmment. If, instead of the square method of planting, the hexagonal is to be used, it would be necessary to estabish twice as many points on the boundary and in the line parallel to same to determine the position of the trees in alternate rows. 
CHAPTER VI.

\section{SETTING AND CARING FOR THE YOUNG TREES.}

'The tract of land to be planted being laid out with stakes to mark the position of each tree, it is next necessary to have some way of lotromining the position of a tree where the stake stood after its

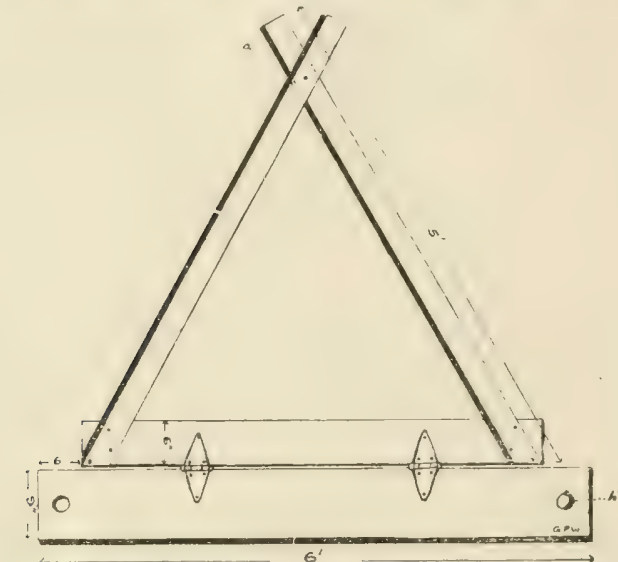

Fig. 25.-A simple apparatus used in setting
trees, (Original) removal in the digging of the hole. A simple but satisfactory apparatus for doing this is shown in Fig. 25.

This is placed against the stake at the point $a$, pins are then driven through the holes at $h$ and $h^{1}$, thus securely fastening the frame to the ground. The portion in front of hinges is now thrown back and the hole dug. Afterwards the front and main portion of the frame is again moved forward over the hole and the tree placed in the erotch at point $a$, which on'responds exaletly to the place where stake originally stood. With such an apparatus grat acelracy may be attained. The hinges shown in figure are not a necessity as such an apparatus may be made without. but is lese convenient as it must he removed from stakes entirely, while holes are buing dng. A straight piece of board with noteh in center and hokes or notrhes at arch whe for the stakes is frequently used.

\section{DEPTH TO PLANT.}

The rute is to plant trees in the orehard slightly deeper than they grew in the nursery, or in other words, the hud union should be at the surface of the gromud when the tree is set. The depth of planting may he varied slightly without any apparent detriment to the srowth of the trees, but all things being considered there is mobably no better depth than is indicated by the bud union at the ground line. and eare must he taken not to plant tro deep as such may pesult in the death of the trees.

\section{FILLING IN THE HOLE.}

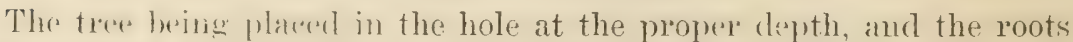
being spread naturally, the soil is now earcfully paroked about them. The entire spares about the crown should be closely filled with soil, and the rareful planter will use his hands in doing this work. After the roots have heren properly eared for, the shovel is used to fill in the 
rest of the hole. It is always well to pour a bucket of water into the hole before it has been entire? filled. so that the troe may have plenty of moisture and also that the soil may he hetter pareked atwout the roots. After watering, the hole should be filled in completely.

\section{IRRIGATING THE YOUNG ORCHARD.}

The first one or two irrigations after planting may be dome in fourrows made previously, and in which trees have been set. While this method insures an abundance of water at the start, it may result in damage beeanse of the baking of the soil about the trees and should not be continued for any length of time after the trees are set. It is much better as a eneneral rule 10 irrigate he means of smaller furpows on either side of the rows, containing small heads of water rum long enough to thoroughly saturate the soil surrounding the trees. The tendeney to bake will not be nearly so great as when the ground is actually flooded. As soon as pussible aftere irrigation, the "ultivator. spring tooth harrow, dise harrow. or other suitable implement should be used, so that the moisture may be better conserved and so that all tendency of the soil toward haking. may be eliminated. In serotions

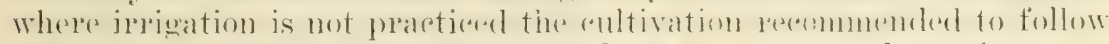
irrigation. shomld be answentionsly done to anselve the moisture so necessary for the proper growth and development of the trees.

\section{PROTECTORS FOR YOUNG TREES.}

Irome trees are always liable to attarek by rabbits and other rodents. and alre also subject to sim seald during the summe- season. As a protere

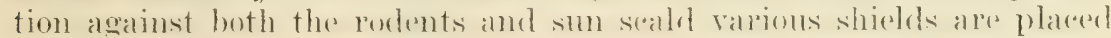
about the trunks. Sometimes a eylinder of heavy paper is used, sometimes wire sereenning. probably best of all alre wouden protectors made very thin from some pliable wood. These should be left the natural rolor and never painted black as sum seald may be worse if blark protectors are used than with none at all. $\Lambda$ common lime whitewash is a splendid sun seald preventive. 
CHAPTER VII.

\section{PRUNING.}

\section{CUTTING BACK THE YOUNG TREE WHEN SET.}

It has already been said that a one-year-old whip is the best tree to plant. Such should be eut back when planted, because of the damage which has resulted to the root system in digging and the consequent disturbance of the balance between root system and top. The root hairs, the function of which is to take up the plant food in solution from the soil, have been practically all destroyed, and new ones must he formed before the tree can be supplied by the roots. It is conse(fuently dependent, in starting at first. principally upon the stored-up plant food in the top and must grow for a short time, at least, almost independently of root action. This being the rase, the less top that there is the better chance will the root system have to make a rapid recovery and renewal of root hairs. The height at which this one-yearold tree should be left will depend upon the distanee from the ground that it is desired to make the head. The tendency now is to head trees as low as possible, and still not interfere with eultivation of the orchard. The writer ean see 10 good reason for heading apple trees more than twenty inches above the surface of the ground. This gives enough trunk for a beautiful, shapely tree, and if later pruming is properly done there will be no trouble about cultivation. As the first pruning may largely determine the height of head, a short discussion on the advantages of a low-headed tree will not be out of place here.

\section{LOW HEADING.}

In California, as well as practically every place where apples are grown, there are times when the sun is very hot and sun seald of the hark may take place to the great detriment of the trees. Surh injury makes a favorite place for the flat-headed or so-called sun-borers to gain (ntrance and do their work of destruction. Wnowing this, is there any good reason for leaving a great high trunk. very often unprotected in any way exposed to the action of the sun? The destruction wrought by sum scald and its attendant borers in California is so great that low heading of trees can not be too strongly recommended.

Most of our orchards are set out for commercial purposes and it is expected that the income from them will be a good one. As in every cther business, it is necessary to keep down expenses to the minimum in order to make good profits. The cost of picking fruit is greatly increased when it is necessary to climb tall ladders to get it.

A certain height of head having been decided npon at planting time. -we will say twenty inches for the purpose of illustration, as well as 
herause it is helieved that this is about the right height--it is obvious that all branches which form the scaffold or fiamerork of thr tree.

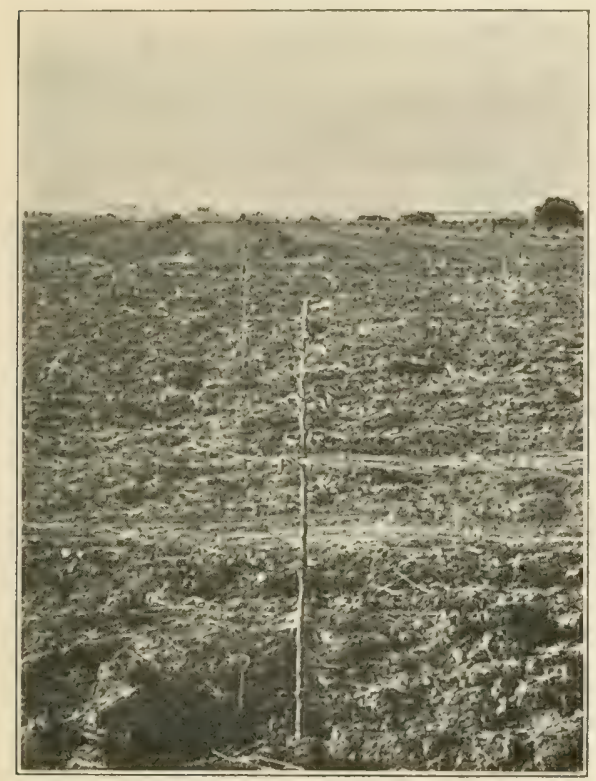

Fig. 26.-A tree cut back to thirty inches in height when set. (Original) should not emanate from about the same point in the trunk, because of crowding and consequent weakening of the framework. There should be at least from ten inches to one foot allowed for spacing these branches for the very best results. If then we desire to have our apple trees headed within twenty inches of the ground the newly set tree should be eut back to a height of thirty or thirty-two inches. 'The current season's growth will be in the form of many laterals from this thirty inches or more of trunk, and if everything is favorable they should develop almost throughout its entire length. See Fig. 26. The practice of rubbing oft shoots low down on the trunk is very often followed during the first summer. It is douldful if it pays to do this as the tree needs lots of follage for its hest development, and the chances of sun scald and its attendant evils are also increased hy this practice. Noderate summer pruning may. however, be done, and the second season there should be plenty of branches to choose from in forming the framework.

\section{SELECTING THE FRAMEWORK BRANCHES THE SECOND SEASON.}

Only a glance is necessary in practically any of the older orehards. when it will be seen that very little attention has been paid in the past to the careful selection of a propex number of branches rightly spaced. Sinch trees as the one show in Figs. 27 and 28 are not at all nieommom. This type of head is decidedly had and has no place in the reerently planted orchards. A great number of weak crotches are inevitable in such cases as this; no larger head can be formed than on a lesser number, and it will not be nearly so thrifty, but worst of all. the time will surely eome when, because of aceident or otherwise, it will he necessary to prime out some of the large limbs from the framework. The close quarters for pruming will not permit of doing the same with ease, and as a consequence large stubs will be left which always mean disaster to an apple tree. The ends will not heal over, rot fungi will get in their work, borers and tremites find conditions favorable, and what might have been a long-lived tree is doomed after only a few short rear's of productivity. 


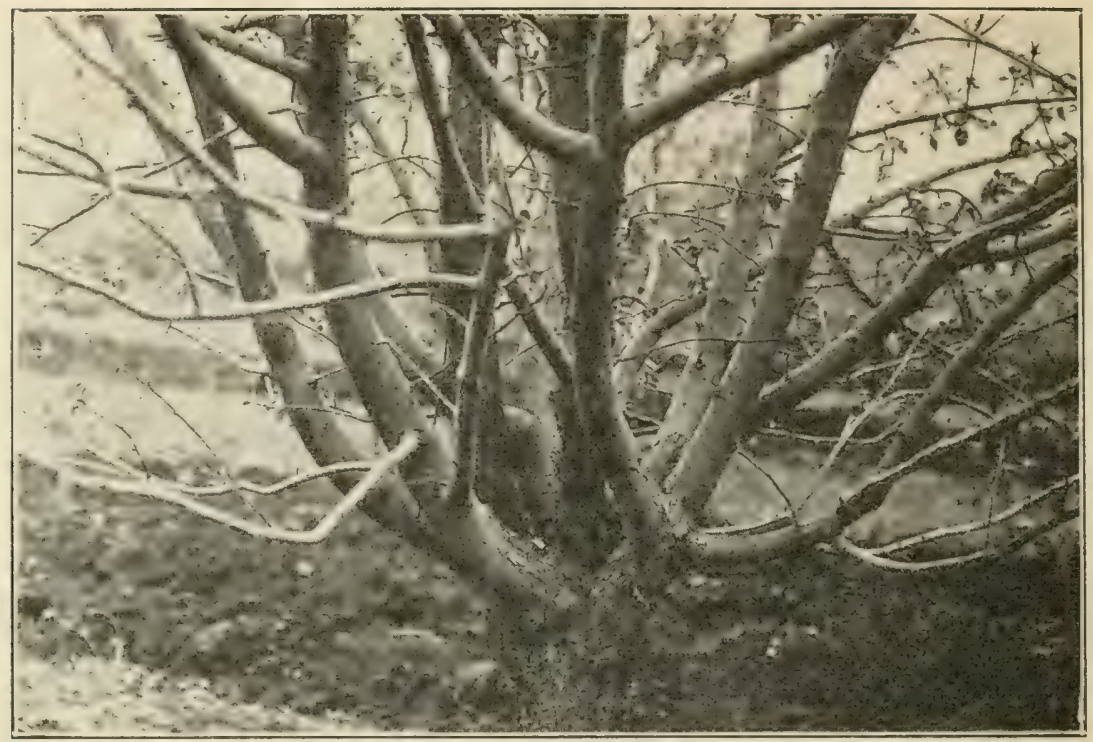

Fig. 27.-An apple tree started with too many framework branches. (Original)

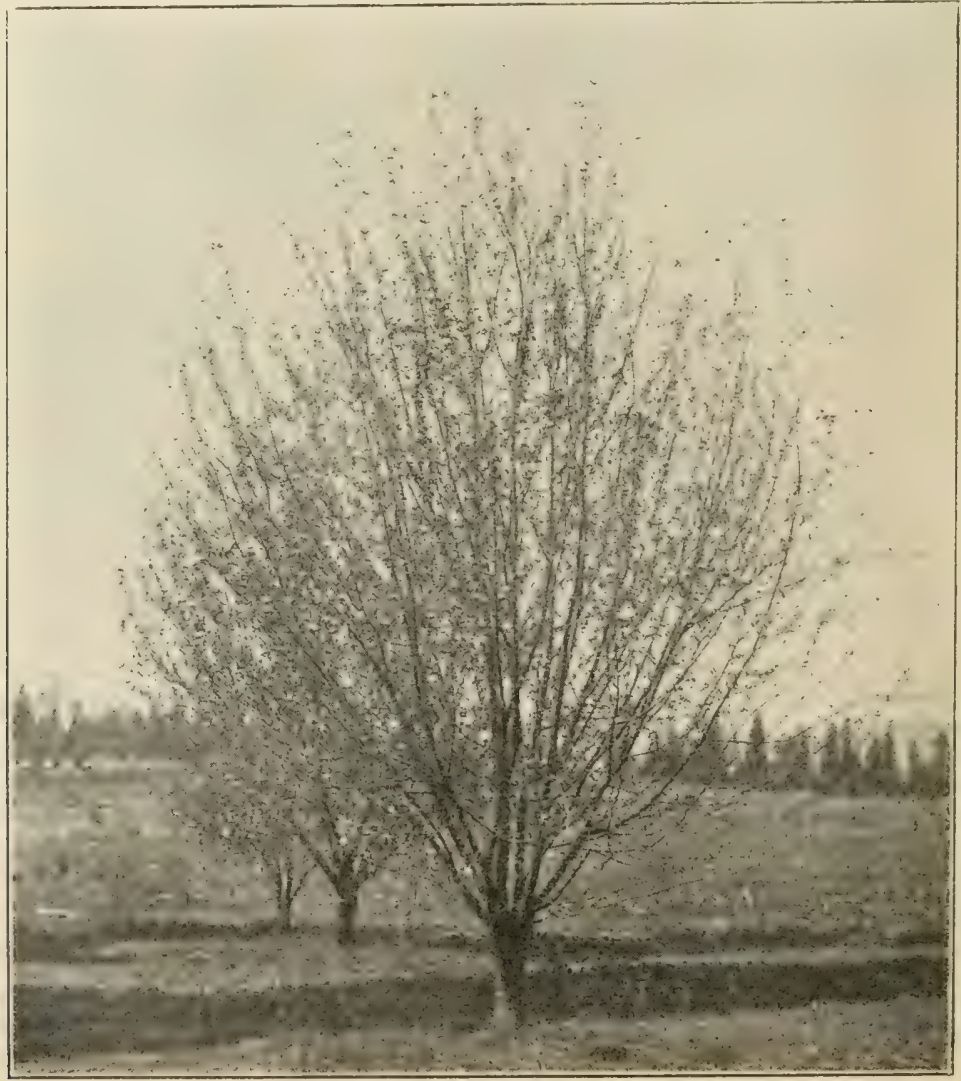

Fig. 28.-The same tree as the one shown in Fig. 27, illustrating the willowlike growth of the top. (Original) 
From there to five hranches ane plenty, when callofully selected in legard to spacing and balanoing the head, for any apple tree. Many prefer three becanse of the fact that just as large a head can he formerl ilyon them as on five, and there will not be so much chance for crowding. Again, the lesser number is desirable because of the extra size they will attain and the consequent ability to hold np greater loads of fruit. Decasionally four or five are left rather than three because of the liability of breaking off branches in cultivating. etc. If one out of three scaffold branches is broken the head is very apt to be unbalanced and difficulty may he experienced in getting it shaped up well afterward, where if there were fom or five and one should get broken the ehances would be more favorable.

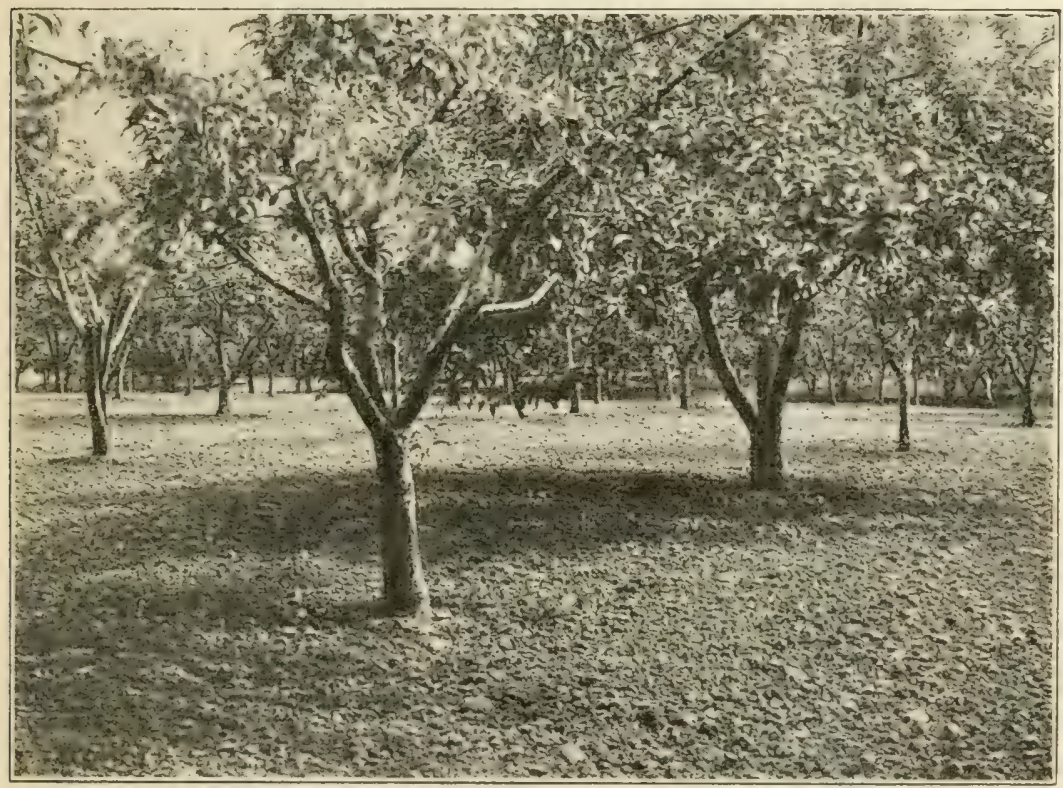

Fig. 29.-Old apple orchard started with only three scaffold branches.

(Original)

Fig. 29 shows one of the oldest orchards the writer has seen, which was started with three soaffold branches. While the spacing of these was faulty in this case, the trees are much better than they would have heen had more branches bern left. Fig. 30 shows an apple tree after the second rear's proming. which has been well headed and which has only three branches left to form the framework. Fig. 31 shows another well-headed tree of the same age, in which five have been left instead of three. Either tree will make a good growth, but the former will develop the stockiest branches and should be a little better tree at the and of the growing season. The branches selected for the framework should not be left in their entirety, but should be cut back as shown in Figs. 30 and 31 . If they are left without cutting back, slender willowy growths will probably be the result. If eut back to lengths of twelve to fourteen inches a heavier growth and a greater increase in the 


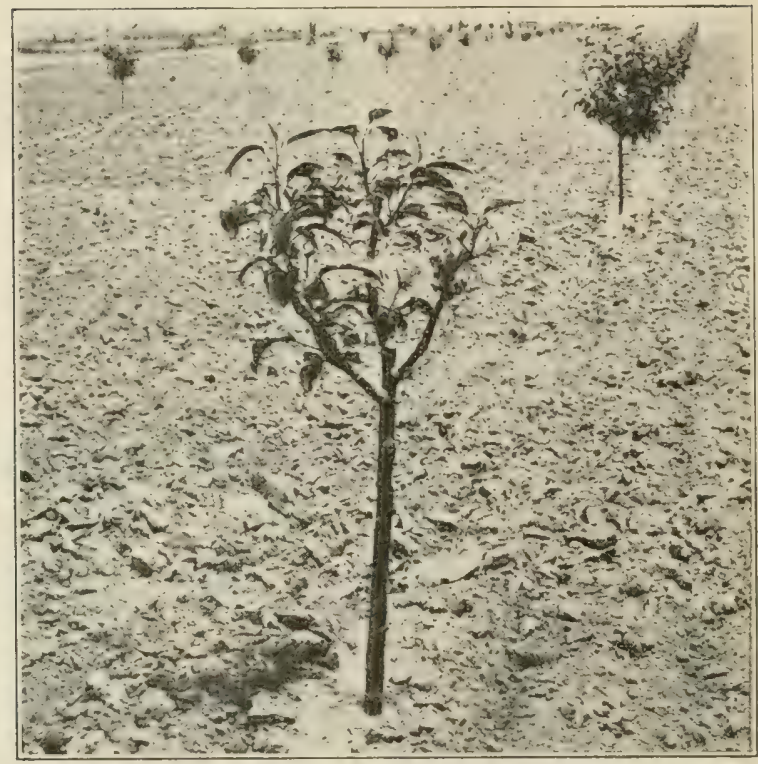

Fig. :0.-Young apple tree after the second season's pruning, showing a head started with three scaffold branches. (Original)

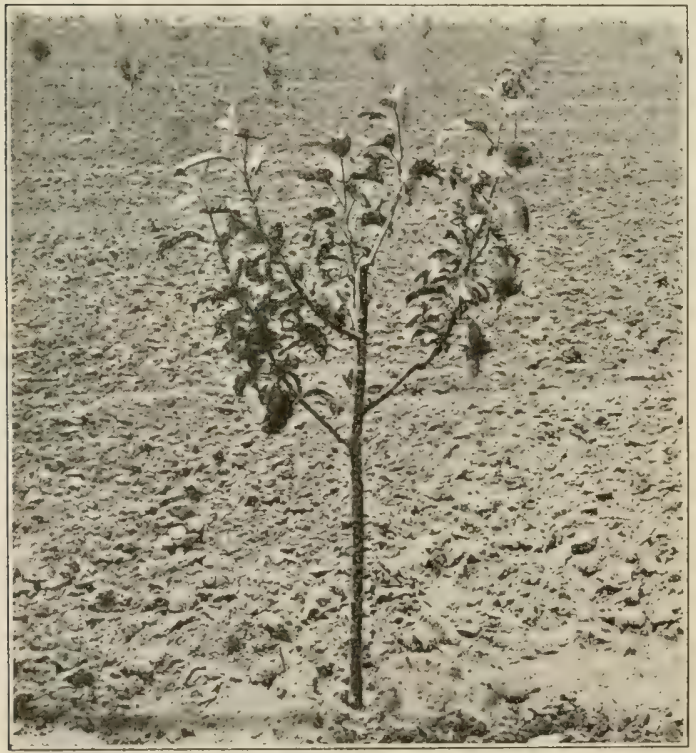

Fig. 31.-Young apple tree after the second season's pruning, showing a head started with five scaffold branches. (Original) 


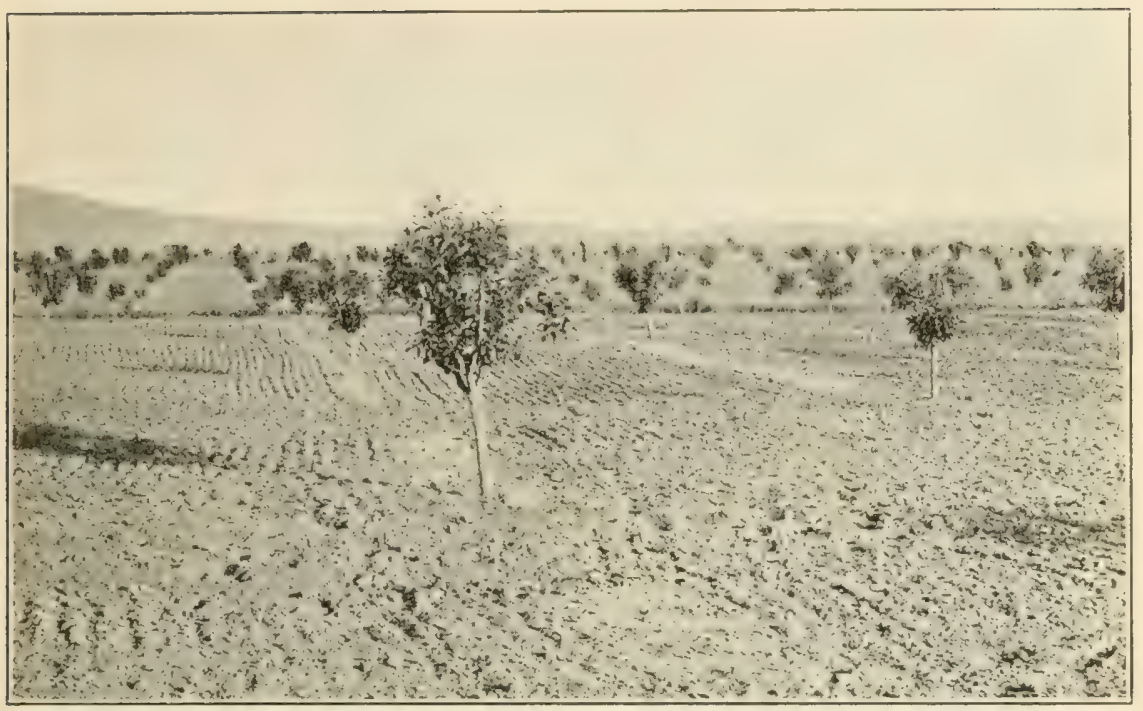

Fig. 32.-Young Winesap tree in foreground which has been heavily pruned, photographed at beginning of third season.

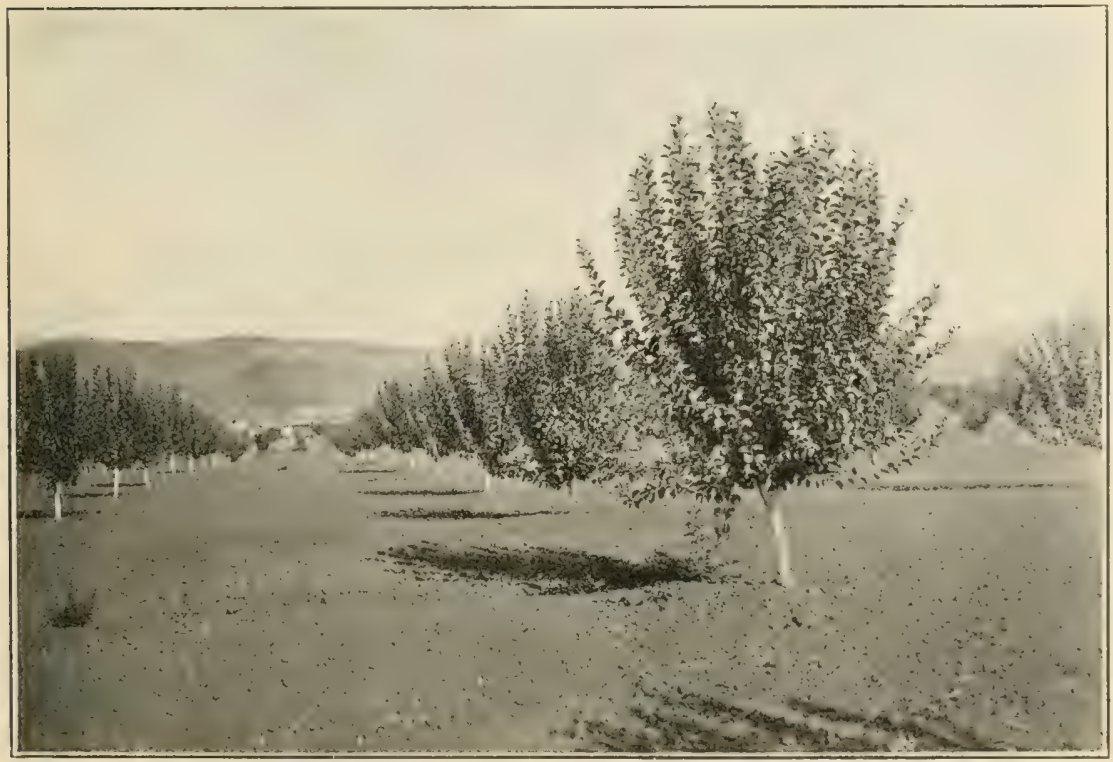

Fig. 33.- Same tree shown in Fig. 32, after season's growth. 
liameter of the twigs will take platee. The value of this heavy cutting back is well illustrated in Figs. 32: and 33 which show the same tree. The first picture was taken parly in the spring and the second on September 21st.

In the case of most varieties of trees, at least, it is best to cut to outside buds when the second season's pruning is done, in order to spread the head. The amount of spread will, however, depend largely on the variety, and whether outside or inside buds are left at the terminals of the twigs will depend upon this varietal factor. For instance, the Winesap has a great tendency to spread and grow bushy, and in order to make it grow upright, or at least to increase that tendeney, rutting should be done just above an inside bud. On the other hand,

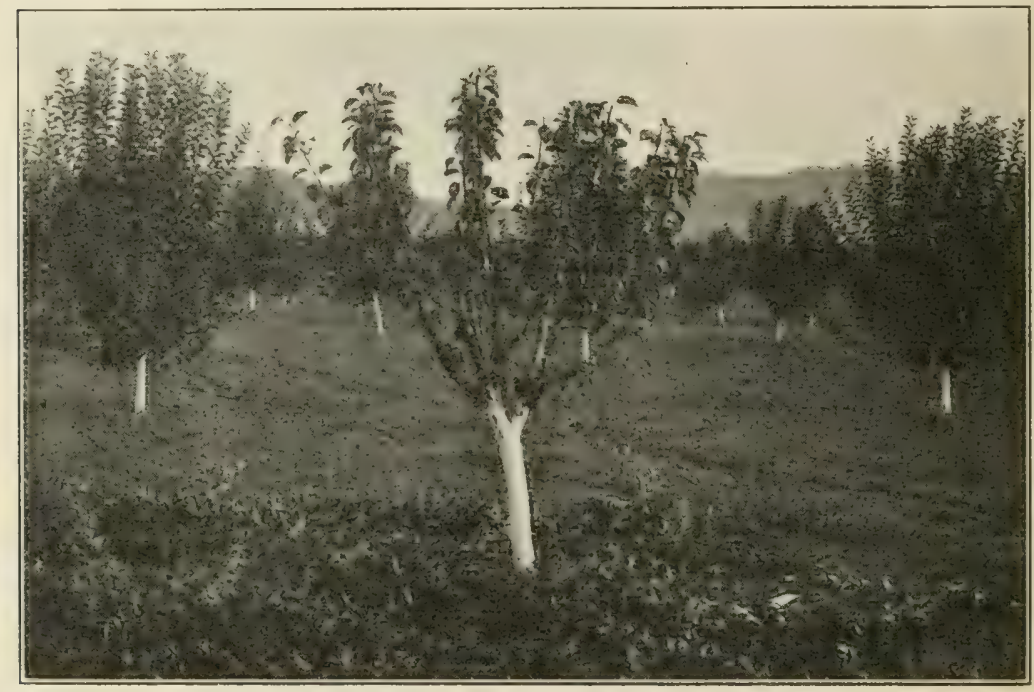

Fig. 33a.-Same tree shown in Fig. 33, after being pruned.

the Rome Beauty tree has a habit of growing upright, similar to the Bartlett pear, and by cutting branches in each case just above outside buds the tendency will be for the branches to grow ontwardly and thus spread the head. More attention to this particular phase of the pruning operation will be necessary during successive seasons than during the second.

The desired number of branches having been selected and cut back as shown in the figures, the tree is now ready for the third season's growth.

\section{PRUNING THE THIRD SEASON.}

Fig. 34 shows the ideal type of head after the third season's pruning, when three seaffold branches have been used in forming the framework. It will be noticed that on each one of these have been left three of the season's branches, selected so as to aroid bad erotehes, properly spaced and eut back just as was the previous season's growth. Thus we have a tree with a trunk which has had three years' growth. From 
this trumk are three branches which have had two years' growth, and in turn each one of these supports three main branches with a fow laterals or fifteen for the entire tree. which have had only one your's growth. If instead of the fire saaffold branch tree we develop a head with three there would be only nine of the one year old hranches left. which, however, is enough with the laterals that they in turn will throw out to make a big tree, capable of hearing just as much funit as the former, and having the advantage usually of extra strength of branches.

A slight modification of the sistem recommended for the first three roars is used in heading the young fravenstein trees in the Sebastopol

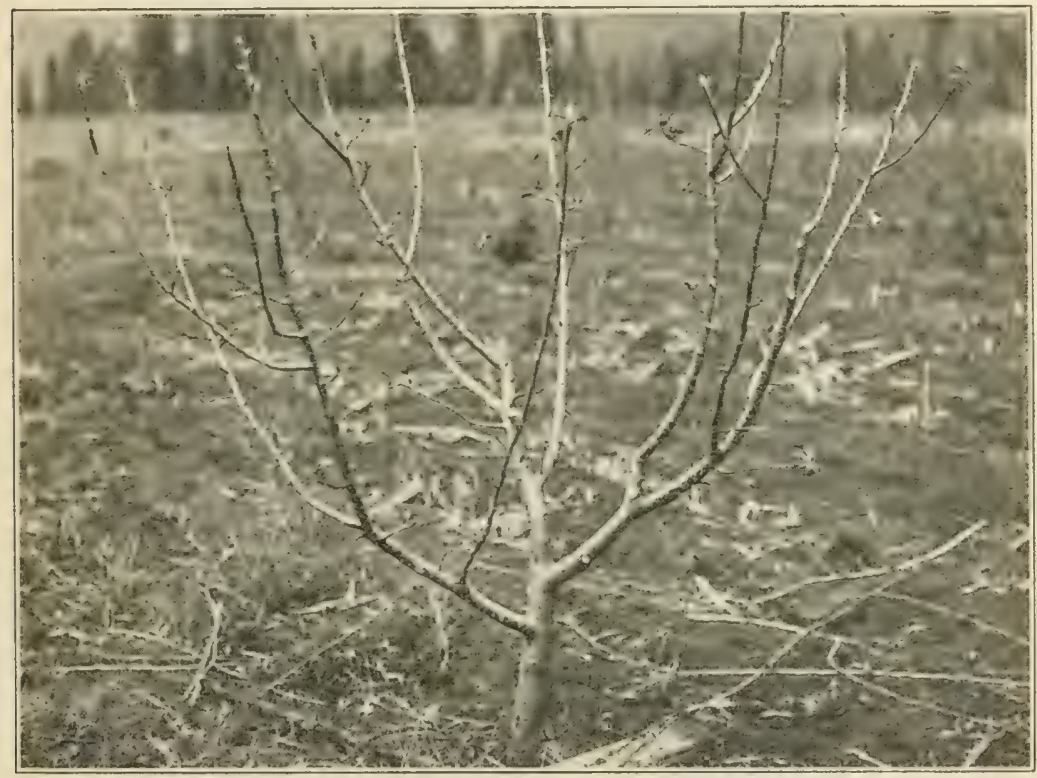

Fig. 34. - $\mathrm{A}$ young apple tree, well headed, after the third season's pruning. (Original.)

section. This tree makes a splendid growth under the conditions existing in that section, and in order to prevent crowding in the head, to render cultivation easy close to the trees, and to develop strong branches, three are left during the second season and cut back as already suggested. Only one branch is allowed to develop on each of the three limbs of the second season's rewth. and is cut back the third season. so that the tree still has only three main branches, but each nne "ut back so that the height of the head is increased by only a couple of feet. Fig. 35 shows a young Gravenstein tree at Sebastopol with three selected brauches cut hack to 7 inches the beginning of the second season and allowed to develop additional length the third. The fourth season two or three branches are selected on each one of these. In this manner a little higher branching head is developed, but one which is very strong (see Fig. 36), due to the growth being thrown into only three branches, well cut back for two seasons after planting. 


\section{PRUNING THE FOURTH AND FIFTH SEASONS.}

At the end of the third season a shapely head should he formed and such a framework for the future tree developed, that prunirg ought not to be a difficult matter. Too often do we find orchardists neglecting the work after this time. The first three seasons while trees are small the task is neither expensive nor difficult, but as they grow there is a rapid increase of both expense and difficulty of pruning in general, and the tendeney is to be rather careless afterwards. It must he re-

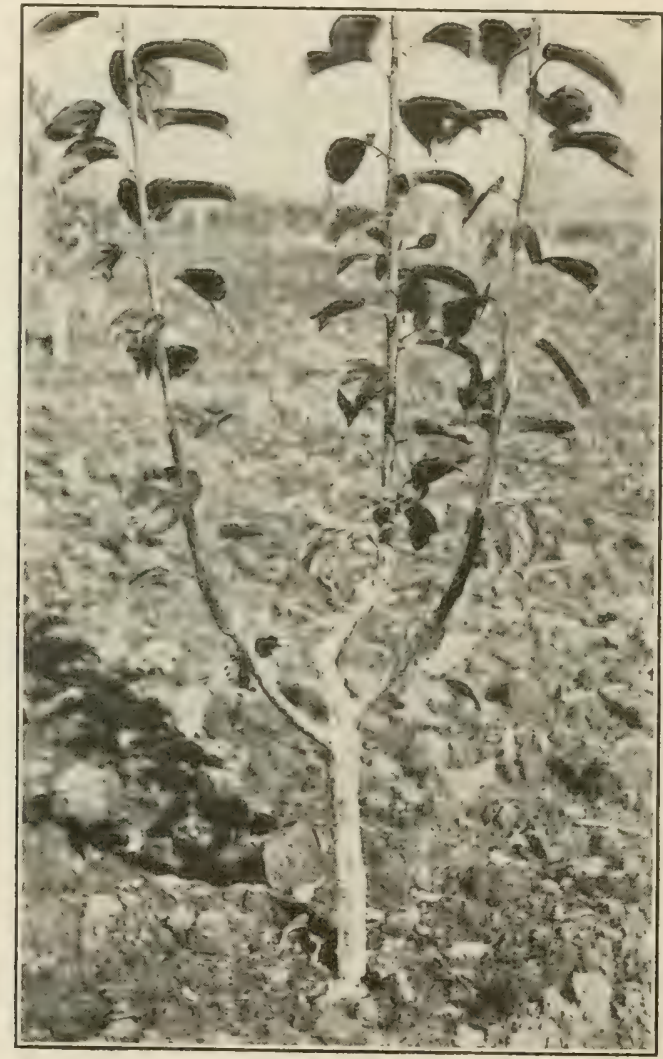

Fig. 35.-A young Gravenstein tree after the third season's pruning, shaped after the methods used in the Sebastopol section. (Photograph by O. E. Bremner)

nembered, however, that pruning for the best results must not be neglected for a single season. Careful, anmual pruning. beginning the first season when the trees are set and continued until they no longer bear crops, will do more toward making a success of the apple business than practically everything else. Neglect for one or more seasons, followed hy very heary pruning as a result, is not conducive to regular bearing of the trees, nor to successful apple culture.

During the fourth and fifth seasons the trees will bear a little, but should not be allowed to overload themselves. The orchardist should still devote his anergies toward growing trees and not fruit. All inter- 
furing branches should be removed. The balanee of the head should he preserved and at least a moderate amount of eutting back of branches should be done. Care in entting to outside buds during the cutting hack process will have a tendency to spread the trees if such is desirable, or the reverse operation may he found necessirry. Fruit spurs will have developed by the fifth season and care should he exereised to preserve these on the trunks and larger limbs. where they are so of terl

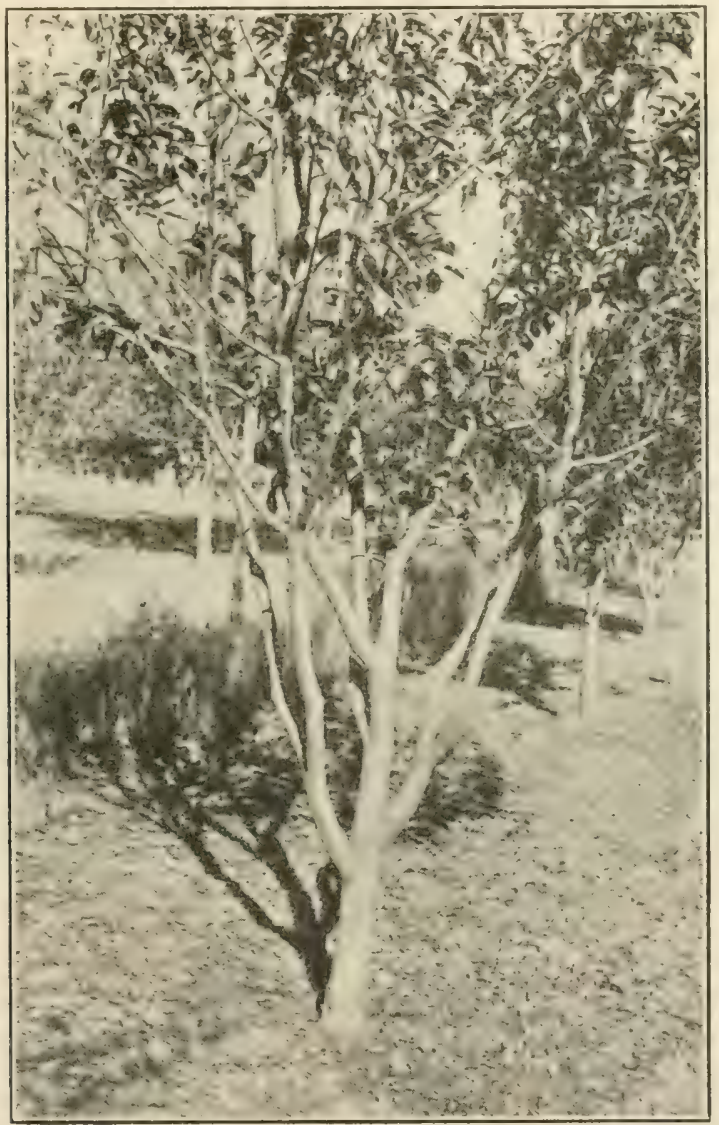

Fig. 36.-A tree with a very strong framework developed by heavy cutting back (Photograph by O. E. Bremner)

"ut off by pruners. One of the mistakes most commonly made in pruning apple orchards is the "utting away of these spurs. Lnintelligent pruners will almost always begin cutting from the ground and the removal of these valuahle spurs is the result. Orchardists should insist that pruning he done very largely from a ladder, as the tops of the trees need a good share of the attention in this work. In fact, if hearling has been well done there should be practically no cutting from the ground, except possibly of a few succulent spronts. 


\section{PRUNING MATURE TREES.}

Correct heading and careful annual pruning of the apple tree for the first five years simplifies the pruning operation for the years to follow. Except in cases of accident to trees there should be no large liranches to take out. The work thus far should have been done with the idea of leaving just enough large branches to form the best possible head without any interference or crowding. Just as soon as such takes place in later years all branches that have a tendeney to interfere with others should be taken ont before they attain a large size. More

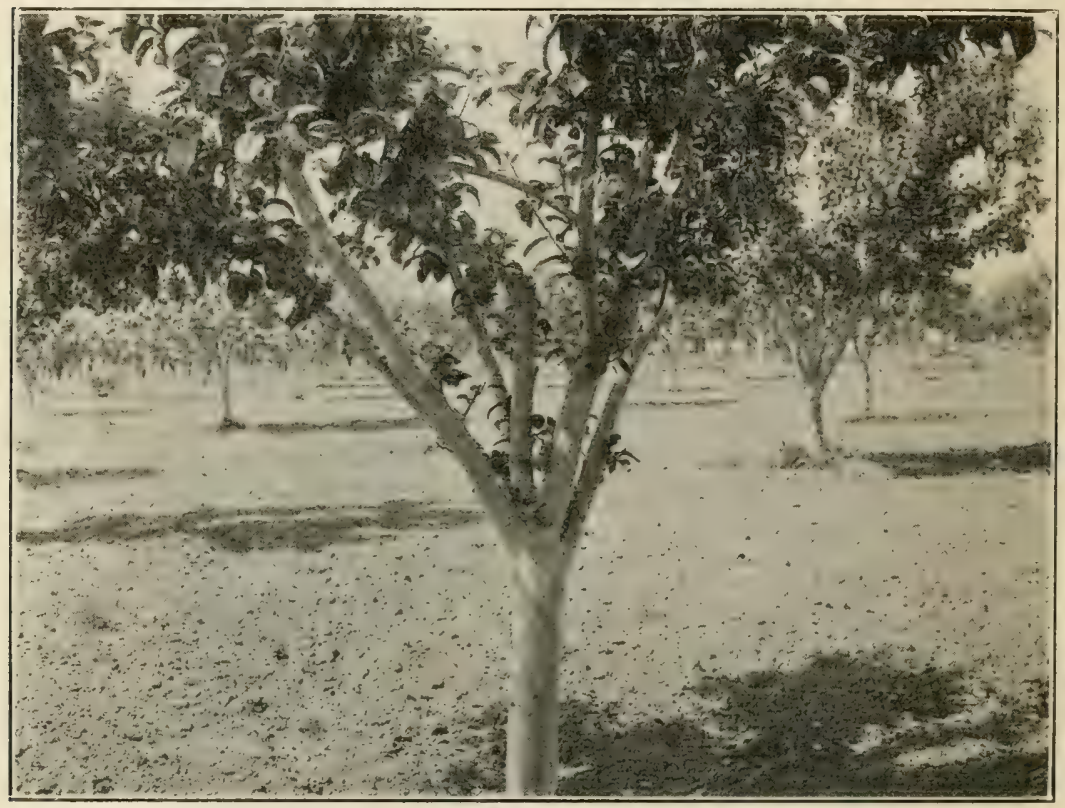

Fig. 37.-A tree of the Yellow Newtown variety, showing the development of fruit spurs from water sprouts, due to summer pruning. (Original)

or less cutting back will be necessary each season, and a study may be made of the habits of growth of different varieties and cutting to outside buds or branches, or the opposite may be practiced according to the needs of the variety. In most cases fruit spurs should be preserved and it may even be necessary to encourage their development.

Mr. W. S. Ballard of the Bureau of Plant Industry, U. S. Department of Agriculture, and $\mathrm{A} \mathrm{I}$. W. H. Volck, County Horticultural Commissioner of Santa Cruz County, have been carrying on some very interesting experiments for the past few years to determine the feasibility of developing fruiting spurs from the so-called water sprout. growth that always develops more or less in every orchard. They found that by cutting back such sprouts early in the summer season, 
leaving two or three inches at first and antting the new growth bark two or three times later in the season, so that by the end of the glowing period there would be formed a growth ahout six inches lone, a fruit spur that would bear excellent fruit the following season could be developed. Fig. 37 shows one of the trees in the experimental orchard near Watsonville. Similar results may be attained ly cutting back these sprouts dmring the dommant season. but it may take several rears to form healthy, vigorous frut spurs. By the smomer pruming methor only one season is necessary. Not only are the water sprouts

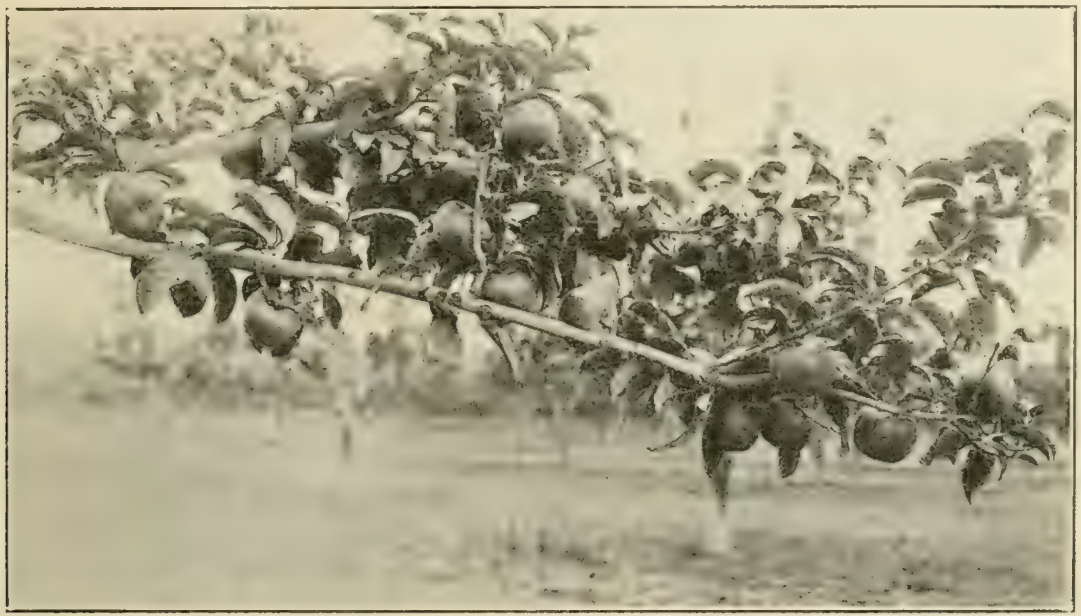

Figr. 38.-Branch well studded with apples, close to the main limb and not in danger of wind damage. (Original)

"ut hack hut also new growth throughout the entire head of the trees. Thus fruit spuls are formed colose to the larger limbs and as a result apples are produced close in as shown in Fig. 38.

The results of the experimental work lone hy Mresis. Ballard and Volck mean much to orchardists who have allowed the destruction by pruning of fruit spurs low down on their trees. Heary rutting back from the top will generally induce much of the so-called water sprout growth low down, which inay he utilized in the development of spurs. Not only the water splouts low down on the trunk may he made over into fruit hearing wond. but new growth anywere on the tree may he handled in the same manner with the conserpuent development of fruit spurs. In places where trees have a tendency to bear light loads of fruit this method of summer pruning, whereby all rauk growtl is checked and the development of fruit spurs encombiged. can be used to very great advantage.

NATURAI. BRACING.

When a tree has not heren well headed or well prumed it is sometines desirable to brace the hranches against possible injury. This is done by twisting together two romg twigs, when a mion between the two will take place, forming such a brace as shown in Fig. 39. 


\section{STUBS.}

Notwithstanding the fact that the practice of leaving stubs in an archard when pruning, has been condemned by expert horticulturists in practically every publication on pruning, there are still a great many trees to be seen in some of our otherwise splendid orehards, with these unsightly and dangerous stubs, bearing testimony to the fact that irruners either did not understand their business or did not are how the work was done.

Branches should always be "ut off close to other hranches or trunks from which they emanate, in which asse healing will take place and the wounds will in time be covered over with new bark, provided that rot

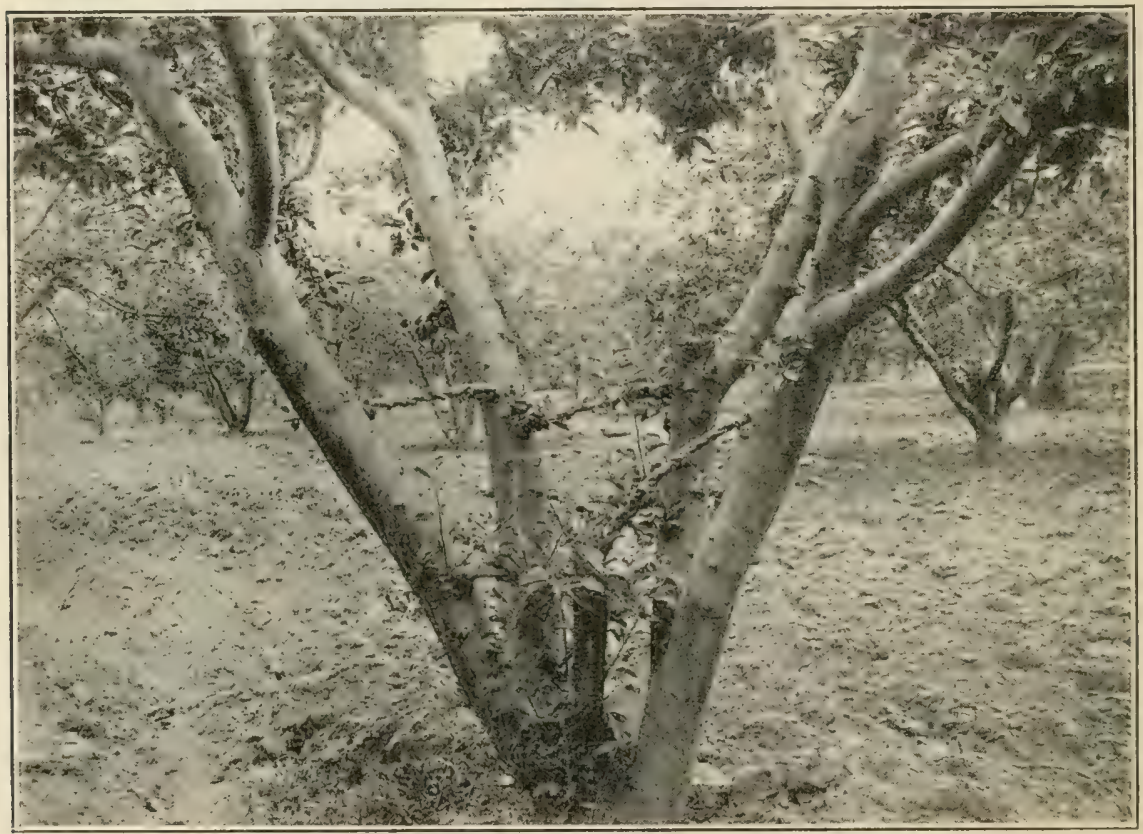

Fig. 39.-Natural braces used to strengthen branches. (Original)

fungi, with their attendant decay, do not develop. If stuls of any size are left on apple trees, they always die barck to the point where the cut should have been made and very frequently dying does not stop at this point, but the trunk or larger limbs are also involved.

The reason for this dying back is very clear. when we consider how the tree gets its supply of plant food that enters into its growth. As cvery orchardist knows, this food is taken from the ground in solution in the water of the soil, and is carried upward through the sap-wood to the leaves. There, through a complex process it is claborated or converted into starch and sugar and becomes available food, which then fourneys downward through the cambium or growing layer of the bark. It is then capable of healing wounds and entering into the life of trees. Before going to the leaves in its crude form there could be no healing. Knowing this it can easily be seen why dying back takes place in the stubs that are left by careless or thoughtless pruners. The apple tree 
is not quick to develop buds and throw ont new urowth from a rut off branch, hence we have a stub without any foliage to manufacture the plant food from the crude material taken up by the roots. and while the salp may journey upward for a time through such stubs, there is no downward flow of elahorated sap from the leaves and consequently no healing. Rot fungi get in their work soon afterwards, drying out takes place, and a tree may be ruined in a rery short time. Nany an orchard in California has either died outright or beeome worthless because of the careless leaving of stubs.

\section{TREATMENT OF WOUNDS.}

Since drying ont over the cut surface takes place very rapidly after a branch has been removerl, it has been the practioe to paint over wounds to prevent this drying, thus giving the healing process a better chances to operate. It is probable that the idea of painting has been carried to the extreme and too much dependences has been placed upon it. A branch can not heal, as has already been pointed out. unless the cut has been properly made. There has been a tendency among some orehardists to eut without any care whaterere and then paint heavily,

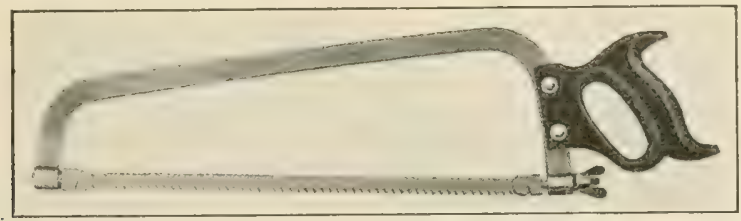

Fig. 40.-A good type of pruning saw.

"xpeseting the treatment to work the miracele of healing against nature is way. It probably does not pay at all to treat small cuts. and nuless the branch removed is three inches in diameter or more. the time and labor spent in painting would probably be lost.

When treatment of wounds is thought to he neecessary there is nothing better to use than a common lead paint. Certain wrades of asphaltum have also been used with suceess.

\section{PRUNING TOOLS.}

Much time is often wasted and sometimes damige done to trees leceanse of the use of poor tools. Practically all the pruning work about

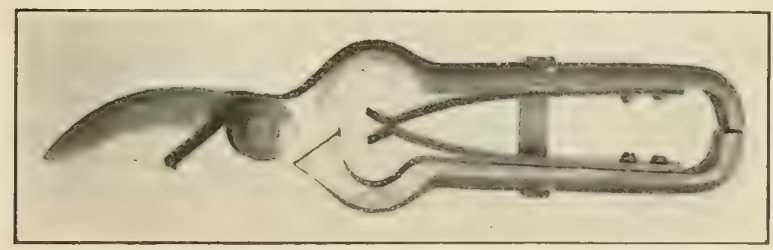

Fig. 41.-A good type of pruning shears.

an orehard can be done with the saw shown in Fig $t 0$ and shears in Fig. 41. The former has a blade which ean be inclined at any angle, so that it is possible to cut in almost any kind of a crotch. The blades. when hroken, "an be easily removed and replaced at small rost. 


\section{TOP-WORKING APPLE TREES.}

It frequently happens that varixties of trees are found, when they come into bearing, to he different from those that were ordered; again, varieties may have been poorly chosen and found to be madapted to the conditions where they are set out. In either case grafting over to some other variety may be necessary.

In the case of two or three year old trees this process is very simpl. and may be done without any appreciable injury to the trees. Such young trees as these can be rery easily budded by inserting buds of the desired variety into small branches low down. Several branches "an be selected because of their placement being such as to be desirable in the formation of the head. 'The best time is in August or' September. The following spring, if the buds are found to be green, indicating that they have minted with the bark of the trees. Hanches should be cut al way just ahove. thus throwing the strength of the tree into the huds. when they should make a very rapiel growth. If trese have large tops it may not be well to cut them all away at once, but to leave a portion of them until the huds have made a good stant, when the entire tops can be removed.

If grafting is preferred to hudding, lareer limbs may be chosen. In fact, if the tree is only two years old it may be sucoessfully grafted hy cutting it back helow the hranches and inserting one or two seions, acoording to the size of the trunk. There al' several methods of graft. ing, the fwo most (ommon being known as kerf and cleft erafting. The first consists of the insertion of a scoun in a $V^{\prime}$-shaped opening made in side of limh, the seion heing shaped to fit tightly into this opening. where it is immediately covered with wax. Cleft grafting consists in the splitting of the ends of the sawed-off limbs and the insertion of scions pleviously cut at one end, so that the cambium layer may be brought into contact with the rorresponding layer of the limb being wrafted. Whether eleft or kerf grafting is done the scions should be sloped a little outward, so that the cambinm layers will cross, otherwise there may be no point of contact between the two and as a consequence no union. Crossing is all that is necessary to insure a good union. Waxing to exclude the air should be carefully done.

The scion should he made from one year old wood with well formed, thrifty buds taken from a good producing tree. Suculent water sprout growth is not desirable for scion wood. Two or three buds are sufficient to leave on each scion and the ends, if cut, should be waxed over.

What has heen said in regard to grafting youmg trees will apply to old also, but very large limbs should not he chosen for grafting. Budding may be successfully done in young growth low down on older trees. If limbs two inches in diameter or inore are cut off for the insertion of scions mole than one should be put in a stuh. In the case of very large limbs, several must he inserted if the healing of the cut surface takes place entirely around the stub. A scion should not be rxpected to heal for more than an inch and one half or two inches on 
(ateh sicle, and enough must he used to heal the stuh entirely around, or she drying out and the death of parts not ted hy the downwar flow of sap from the leaves of the scion will take plare. Wrakening. if not eventually killing, the stub and its graft.

Many experienced grafters prefer to leave a ronsiderable portion of the top of old trees for one or two seasons after grafting. 'This is undoubtedly a good practice, but such should not he left long enough to interfere with the growth of the grafts.

Aphis are very often exceedingly destructive to youmg grafts and eare should be taken to control them by means of sprays hefore they bring about permanent injury.

\section{GRAFTING WAXES.}

A good grafting wax heing one of the requisites for sucoesstul grafting, the following, copied from "Fruit Growing in Arid Regions," by Paddock and Whipple, is given:

"*** There are the waxes applied warm with a brush and those applied cold, the heat of the hands being sufficient to make them pliable. With the first it is necessary to have special equipment to keep the wax melted in the field, and this generally limits its use to a few professional grafters who are prepared to use it. The cold waxes are prepared for use by melting together the ingredients, pouring the melted material in cold water, and pulling it like taffy until it becomes a buff color. It can be kept from season to season by immersing it in water. 'The common formula given for the preparation of this wax is four pounds of resin, two pounds of beeswax, and one pound of tallow. Paraffin may be substituted for the beeswax in this formula; although it seems that the resulting wax is hardly as durable, it serves the purpose very well. By increasing the amount of resin in the above formula to six pounds, it makes a very good hard wax for warm application. Another good wax to be applied warm is prepared by melting together three pounds of resin, one pound of beeswax and one pint of raw linseed oil." 


\section{INTERCROPPING.}

During the five years or more while the young apple orehard is coming into bearing it is often quite a problem for the man of limited means to make a living, and he must either secure work elsewhere or grow crops between the trees, out of which he can make a sufficient sum 10 keep up expenses until a profit can be made from the apples.

Cropping of land between orchard trees, even while young, has sometimes been discouraged, but the writer can see no good reason why such should not be done even after trees come into bearing, provided that reptain precautions are exerecised. The orchard should of course receive first consideration and no erops of any kind should be grown between the tree rows, which in their "are would detract from the care of the trees. In this connection it is unwise to grow crops that require water late in the summer or in early fall, as irrigation at that time may start new growth or keep) trees growing too long into the winter, in either rase rendering them liable to injury during the winter months, because of the soft unripened condition of the wood.

It may happen that there is scarcity of irrigation water for the orchard. In such case it would also be unwise to plant intererops of any kind and thus take away the moisture needed by the trees.

Crops such as corn, which make a rank growth, might not be best for very young trees, on account of shading them too much.

Notwithstanding these objections that may be cited against an intercrop in the young orchard, conditions are very often such that with the proper crops and the proper care there will be no harm done, and much good may even result to the orchard because of better care due to these crops.

As was mentioned in another chapter, California soils are usually deficient in nitrogen and any leguminous crop is good to grow between the trees, because of its adding this important element to the soil. Peas and beans for this reason are excellent as intercrops, and provided that market facilities for such are good there is probably nothing better that (an be grown. Of the non-leguminous crops may be mentioned potatoes, cantaloupes, strawberries, cabbages, celery, in fact almost any vegetable (rop), and the one chosen will depend in most cases upon the demand for the product.

Field corn is quite frequently used as an intercrop, but is probably not the best crop for the first year, at least. Its tendency to grow very tall if it does well is against it, for the voung trees are very often shaded too much, and as a consequence fail to make the growth that they should. This objection may be partly eliminated by keeping the rows of corn several feet away from rows of trees. thus giving the latter more room. Sweet corn and popcorn, because of their smaller growth and lesser amount of shade, ('ould be grown with less danger of damage than the field corn.

The growing of intercrops is very often discouraged because of the plant food that is taken from the soil, thus depriving the trees of their supply. This objection is certainly weak, for no one should expect to grow orehard trees on land for many years without fertilizing to supply the elements removed, and the growing of crops between the trees merely hastens the time when such fertilization must be done. 


\section{IRRIGATION, CULTIVATION-COVER CROPS AND FERTILIZERS.}

The scarcity of water in some parts of the state where apples are grown, and the total absence of rain duxing the summer season, makes the conservation of moisture in the soil one of the important orchard problems. Fortumately, the rainfall during the winter is ordinarily quite heavy and the ground receives a good soaking during that season. If nothing is clone to check the evaporation of moisture after the rains rease and the hot weather comes on, the soil may become too dry in al very short time. Those who are fortunate enomgh to have a good supply of irrigation water are inclined to use it freely. thus keeping the orehard

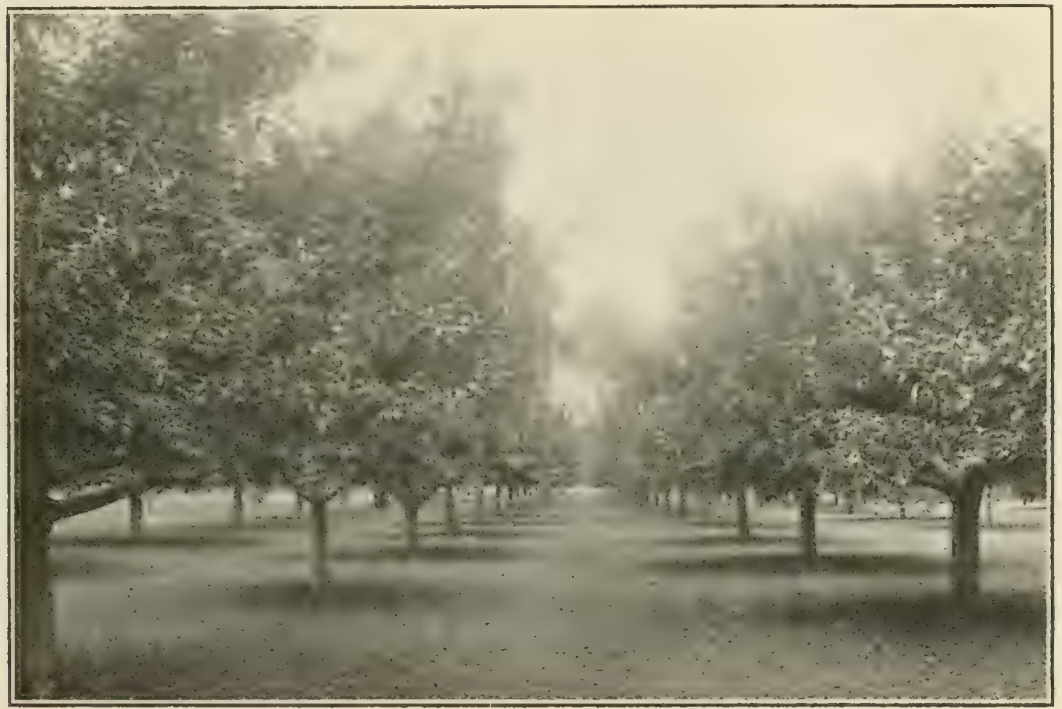

Fig. 42.-Well tilled orchard in Humboldt County.

in a moist condition without any attempt to conserve what is added. Very frequently, it may be said, too much water is used for the good of the orchard, which would be better oft if less were applied and the cultivator used more. The best condition of the soil oceurs not when it is excessively wet, but when it is quite moist and the surface not baked but in a loose, workable condition. Aeration is just as necessary for the best development of the root system as moisture, and an excessive quantity of the latter may eut off the air supply to such an ('xtent as to interfere matrially with the growth of the trees.

It is sometimes difficult to make people believe that cultivation does actually conserve the moisture, but a trial only is sufficient to convince the most skeptical. The reason that it does lies in the fact that the 
"apillary action, by means of which the soil water is brought to the surface and there evaporated, is checked. In other words, the soil is made up of fine particles with spaces in between which become filled with water. As a licuid in a fine tube will always travel upwards and reach a level much higher than outside the tube, so in the soil we find the same tendency, and we may conceive of the water as coming up through myriads of little tubes which remain wide open to the surface unless something is done to interfere with their continuity. Such interference may be brought about by the use of the cultivator during the summer season, when evaporation takes place so rapidly under ordinary conditions; but, as they will soon open up again after disturbance by the cultivator. frequent cultivations are necessary, so that as fast as the mois-

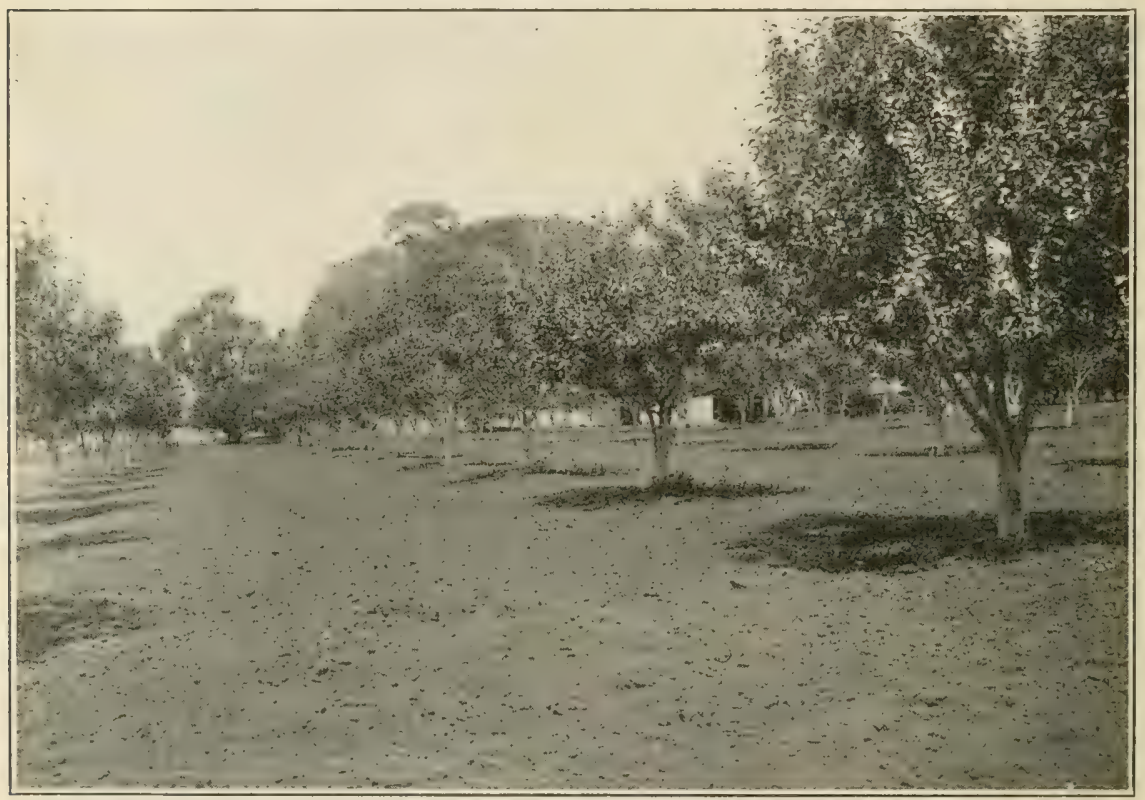

Fig. 43.-TVell tilled orchard in Santa Cruz County. (Original)

ture finds its way to the surface through these tubes, it is checked by again hreaking the capillarity. Figs. 42 and 43 show two well tilled orchards in IIumboldt and Santa Cruz counties. The ideal condition of the soil to prevent evaporation is that of a dust mulch, which may be maintained by working the soil with some type of harrow or cultivator once a week. Some enthusiastic advocates of rlean cultivation have gone over their orchards even more frequently than this.

Besides being a valualle means whereby moisture may be conserved, (-ultivation is beneficial in keeping down weeds, and also places the soil in the best possible condition for root development and the resultant tree growth. It is a matter of eommon ohservation that orchards to 
which frepuent summer cultivations are given make bettel growth than do those whele cultivation is neglexeted. In most partsot the arid Wret. lut not commonly in California, we find conclitions that do not farol summer cultivation. The winters in these places are so rold that noth. ing "an he grown during that season of the year. Conseruently there is

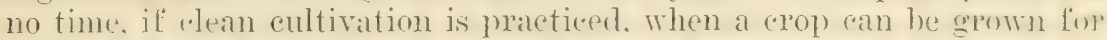
the arlition of nitrogen or humus, henre the neressity of growing a summer cover crop.

\section{COVER CROPS.}

In most parts of California our fine warm winter climate (nables nis to grow "lops of some kind in the orehard during this season. Owing to this fact summer antivation is advorated and is pratrefied suressifully nearly everwhere that apples are grom. Beraluse our soils are diffeient in nitrogen, a leguminous cover cop is pleferable. Among the legumes which have given good satisfartion under one con-

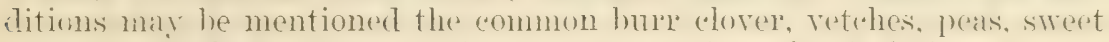
rlorer and alfalfa. Many ohject to the erpowing of alfalfa in an apple orehard, and probahly it is not good practice to sow it moless it is dome with the idea of using it for a cover crop only and not for hay. On hardpan soils there is nothing better than the root system of the alfalfa to penetrate into this hard layer, thus braking it up more or less and enabling the apple roots to go down dereper. When used for this purpose it shomld of rourse be left growing in the orehand more than one season. Then alfalfa is sown it should be liept some distance from the trees in order to farilitate plowing later on, and is only desirable where plenty of water is arailable for irrigation. Srenerally speakines, the enver "rop should be grown only during the winter season, heing plowed muder arly in the spring, if possible, before the rains have eadsed. Frequent "ultivations later om, atter the season heromes warm, will result in enservation of the moisture. If it is not possible to grow a leguninum cover crop, an anmual erop such as rye. wheat or barley may be grown. In this case the principal value would be to better the physical endition of the soil. together with the addition of lnumus. There are places in the state, no dount, where apples are erome and where the rainfall is insufficient to make a cover cop) practical, evon during the winter season. In such cases fertilizing must the done in some other way.

One of the most suceessful apple enowers of the East says that he made his orehard prativally an anmul bearere hy the nse of cover erops.

\section{FERTILIZERS.}

There is nothing better for the orehard than barmyard maune, and while the supply is often limited it is in other wases wasted when it might be used to good advantage. It is always wise to apply this liberally, unless the cost is such as to make it prohibitive.

Commeroial fertilizers have not been used extensirely. but no doubt mould give results undel certain conditions at least. Spraying with nitrate of soda and other nitrates, in the early spring. has been done 
in an experimental way by W. H. Volek at Watsonville. The results that he has attained have on the whole heen excellent, and this method of applying nitrates bids fair to come into general use.

Many of onr California soils are deficient in line and the addition of either air slaked or eroume stone lime might be heneficial. No rules ran br laid down for this work because of the great rarieties of soil that occur in the state. If trees are not doing well it may be that fertilizers of some kind are needed. A soil analysis will serve as a enuide as to what should be added, but must not be depended upon too much. for while it shows what elements of plant food the soil contains, and the proportions of each present, it does not show how much of each is available, so after all much experimental work is necessary.

As stated previously, nitrates are nearly always searce and fertilizafion usually means the ardition of the element nitrogen, either in the

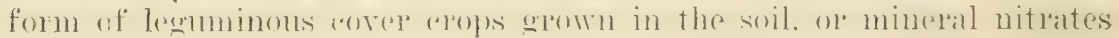
applied direct or in the form of a spray to the trees. 


\section{THINNING.}

One important operation in connection with the handling of our immature apple erop, viz, thimming, is too often neglected. The excuse grenerally wiven for not thinning is that it costs too murh. This is a case, however, where a little extra money invested will add greatly to the income of an orchard. There are records of a number of experi-

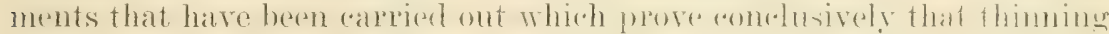
pays, and to neglect the operation means to fail to do one of the most important things in connection with the growing of apples.

\section{INFLUENCE UPON THE FRUIT.}

It is the desire of every fruit grower to produce fruit possessing a good size, high color, fine quality and uniformity. Such is usually impossible unless thinning is practiced.

The size that fruit attains-not taking into cousideration the vamition due to variety-is influenced more or less hy age of tress. stork,

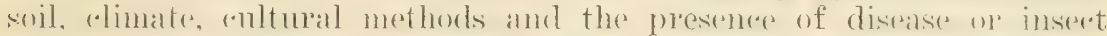
pests. Some of these influences may be such as to prevent the produrtion uf a desirable size of fruil, hut in general our loess will with

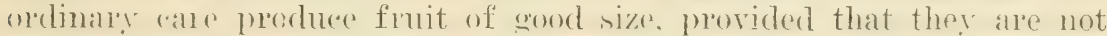
overloaded. The time has passed when we want to place a premium on abmormally large fruit. It is not the purpose to adromate thimming

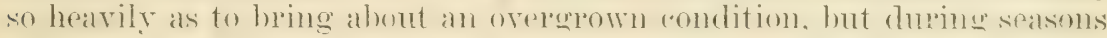
of big crops to thin to a point where the most desirable size for the variety can be attained. Any one who is at all familiar with the mohard business knows that great losses are often oreasioned bratuse of undersized apples.

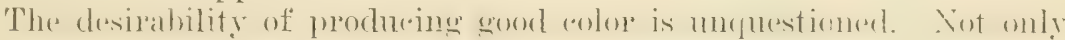
does this please the eye but also adds to the quality. A rosy red Winesaly or Baldwin apple will be sweet and juicy. with a flavor to suit the most delicate palate, while the same varieties grown on the same trees, but uncolored, will be searcely relished. Leaving out of consideration the fact that color influences quality in the valoty. the leautiful red apple will command higher prices on the market than better varieties without color.

While size, color and quality must all be taken into consideration, there is probably nothing more desirable than miformity. and in no way can this condition he hroweht about hether than by thimming: in faret, it is impossible durine seasoms of laree crops, at loast, to serme miformity in size in any other way. The greatest argument in favol of thimning as far as the fruit alone is concerned, is based on the ahove statement. A lack of miformity complicates standardization methods and all the operations of parking, and is not at all desirable in the anning and drying business. If hy thinning, fruit can he made to arerage well in size, a considerable outlay of money is justifiable for the operation.

Another argument in favor of thinning has to do with the presence of the worst insect pest of this fruit, viz, the codling moth. 
If apples are allowed to grow in elusters so that they are touching one mother the larve not only take advantage of the ideal point of entry between the apples. but the sprayer is plared at a decided disadvantage, for he finds it extremely difficult to get the spray where it will be eaten by the worms. Varieties that have a tenden'y to chuster are nearly always riddled hy rodling moth if the pest is present in large numbers. unless the clusters are broken up by thinning.

\section{INFLUENCE OF THINNING UPON TREES.}

As far as the trees themselves are concerned there are three main reasoms why thinning slould he prate ieed: first, it allows them to make

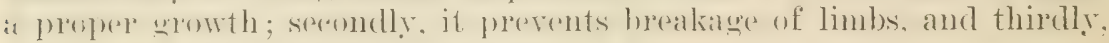
it induces uniform annual crops.

A tree is capable of taking just so much plant food in the way of nitrogen. petash, phesphorice arid. ate.. from the soil through its roots. and carbon from the air through its leaves. An excessive amount of fruit is apt to refunire most of this ford at the expense of a good thrifty gerowth. The desire of most orehardists is to develop a tree to hearing size in the shortest prisibe time. and to have it bear abmedant "rops each seasm. often depriving it of proper growth in so doing. Our trees, I fear, are too often worked to death, and we wonder why in a fow reall' time they hegin to deteriorate and the reops of former rears are not halpested. The splendiel deepe soils so full of plant foods that we find so (ommonly in our state. will do murh towards hringing abont the heary anmual hearing so spreatly desired, hut no soil will last for"rer, and the time will rome when trees, or whatevere else nay he grown onl land tor year after year, will develop large "rops only at the expense of erowth and health, imless somethine is done in the way of fertilizing to build up the soil and thinning to prevent over-bearing.

Thinning to prevent branches from breaking down under their

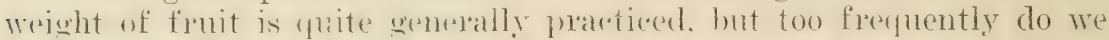
find the prop) dome this duty. A heary erop of apples is mistally follested by a light one. This is mudoulitedly due to the fact that the trees are allowed to bear too heavily during seasons of good crops, conserpently the formation of fruit buds for the next season's "ron is prevented. At tree not only has to mature its crop of fruit and make a rertain amount of growth during a season, but it also has to make fruit huds for the succeeding season, a process which is frecunently rendered impossible by overproduction.

\section{THINNING BY PRUNING.}

The "utting out of wood antaining fruit buds during the domant season may be done as the first step in thimning the crop. Pruning. when dome with the idea of thimning the fruit. must be done intelligently and not by men whose only knowledge of the business consists in their ability to "ut off a hranch because they think it interferes with the propes" shape of the trese. Because of no knowledge of the bearing halits of an apple tree we sometimes see trees from which all the fruit spurs have been "ut as high above the ground as a man ean reach. These are exaggerated cases, but serve to illustrate the fact that too little attention is paid to some of these fundamental principles which lear upon the subject of thinning. 


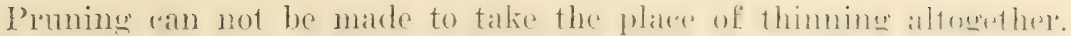
Fruit will cluster just the same on frumed trexs as those muprumet,

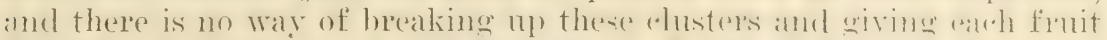
ionu for development. except hy picking off part of it hy hand.

\section{THINNING BY REMOVING THE FRUIT AFTER IT SETS.}

The earliex the fruit is removed the hetfer "hanco will the remainder. have to develop. While no time can be sest, that will mot he subjest to wide variation with seasons and different fruits, in general thinning should be done just as som as possible after the fruit sets and damere of the early. or so-called Jume drop, is over. 'The work may be dome yuite handily with a pair of thimming shears surh as shown in Fig. 4t. These may be purchased at small cost and will greatly aid in the rork.

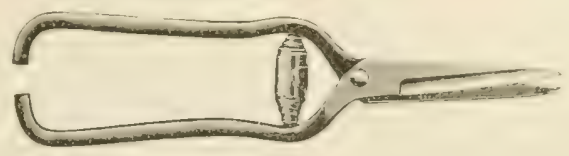

Fig. 44.-A good type of shears for use in thinning apples.

'The amount of fruit that should be left on a tree is, of comrse, an

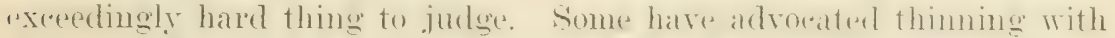

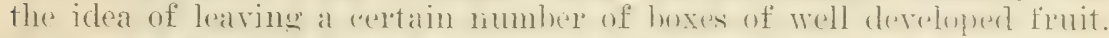

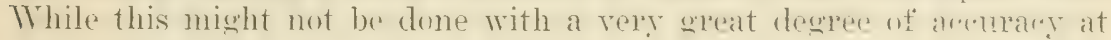
first, those who have tried it claim that in a very short time one will loam just ahout how to spare the apples so that an amomet approxi-

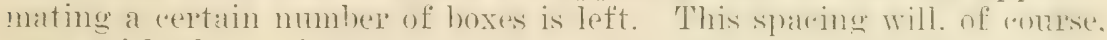
vary with the variety, the average being about six inches. If trees are well set. with frut so that an even distribution wan be hought alout, all clusters should he hroken up until no two alpples tomell, and all fruit on the tips of small twies should he lemoved. Careful. systrmatie work is neressitry for the ereatest sureess. Ile who wors into his orehard with a pole and knowks oft sone fruit here and thepe hate not thimmed. Trute he has relieved the tree of some of its hurden. hut. in all probability, in such a way that he will not be repaid to any extent for his efforts. 


\section{INJURY AND PROTECTION OF APPLES FROM FREEZING.}

It has already heen stated that one of the chief limiting factors in the profuction of apples throughout the various states of the Lnion is frost. It is true that there are certain sections of the country where frosts have seldom or never oremred to the destriment of the fruit (ere). Experionoe of orchaldists in california and elsewhere has led to the conclusion that no sortion. no matter how frec it has bern trom killing frosts during the danger period of trees in the past, ean be said to possess immunity, and there maty come a time when the temperature will (lion) so low that huds, hlossoms and fruit, if not trees, must sule(*umb. There are of course. many places where fine fruit is grown during tarorable sodsons that ate visited by killing frosts periodicolly and

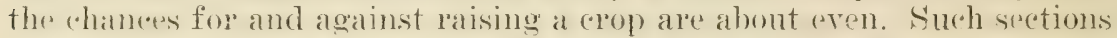
do not offer the best advantages for eommercial orcharding muless some practival neans of protectinge the crop during the danger periond may be employed.

\section{PERIOD OF GREATEST DANGER FROM KILLING FROSTS.}

In the case of apples, the injury is usually done either to the buds, blosioms of small fruit in the early speing, about blossoming time. although a severe freeze during the winter season may kill the buds, which often stand temperatules ranging from tem to thinty degrees or more below zero. The period of greatest danger roresponds rary clusely to the time from when the huds begin to swell in the spring until the fruit has reached a diameter of a half inch. This time is. of conrse, subject to variations in climate, dne to altitude or local conditions.

\section{BUD INJURY.}

Winter or early spring injury to buds may be detected by a discolored area seen in the conter upon cutting them open. The pistil or central organ of the blossom is usually the first part to freeze and, once frozen, futilization is rendered impossible. Blossoms so injured will sometimes develop, and the trees will come out in bloom and be just as beautiful as if nothing had happened. An examination of such blossoms will show the blarexed pistil in the (enter. A peruliar form of freezing of apple blossoms, which has come to my notice in another state. destroys the petals entirely. The rest of the parts of the hlosson develop normally, fertilization takes place as usual, and a good crop of fruit may set on the trees.

\section{FRUIT INJURY.}

offen fruit develops from frost-injured blossoms, but as a rule only when fertilization has taken place prior to the injury. In Bulletin 91 of the Montana Experiment station. Prof. O. B. Whipple gives an interesting accomnt of the parthenocarpic development (development without fertilization) of apples. most of which were seedless and core- 
less and unfit for use commercially. It is a very common thing to find seedless apples or pears during a season following a freeze at blossoming time or shorty afterwards. Fig. 45 is a picture of two Tellow bellfower's picked from the same trees. One apple is almost true to the type of this particular variety; the other is very much flattened

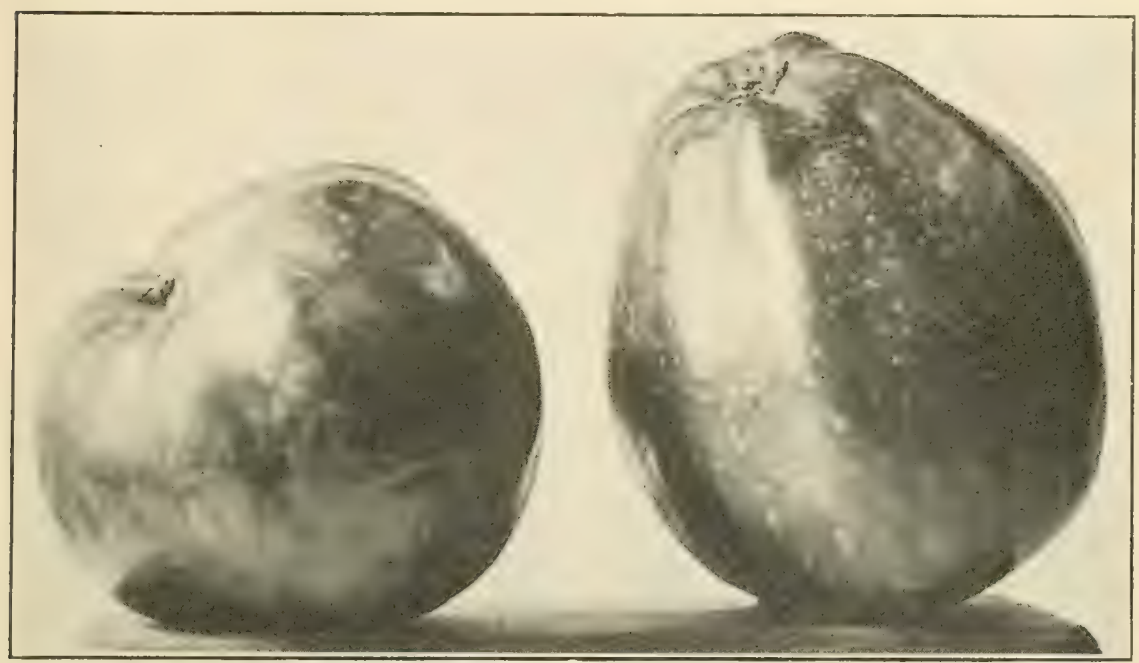

Fig. 45.--Normal shaped Fellow Bellfower on right, abnormal on left because of frost injury. (Original)

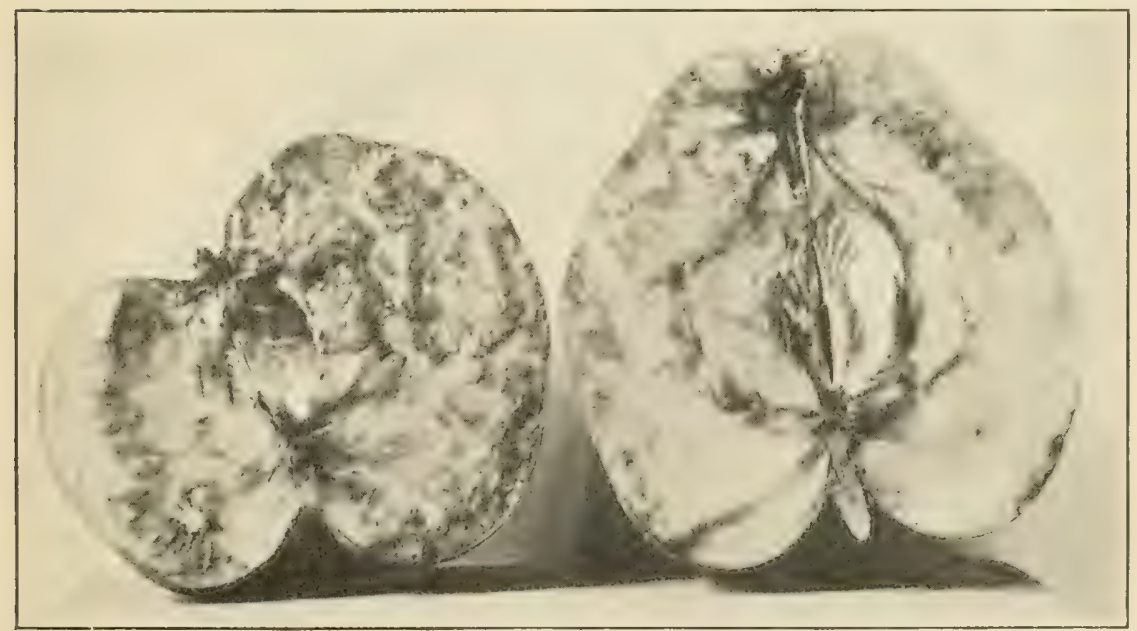

Fig. 46--Normal shaped Yellow Bellfower on right contains well-developed seeds; abnormal frost-injured specimen on lett has none. (Original)

and distorted. Most of the apples in the orchard where these were? pieked resembled the latter. and it was difficult to find a typieal-shaped Tellow Bellflower. All apples of this shape were seedless. This trouble might easily be confused with distortion of apples from the attack of 
purple apple aphis. This pest always leaves the apples small and misshapen, but well-formed seeds are present. Fig. 46 shows the same two apples as in Fig. 45, which have been cut open. A well-dereloped seed is shown in the core of the typical-shaped apple, while the other one has none.

Another form of injury is the so-called frost russet illustrated in Fig. 47. The russeting rery frequently shapes itself in a baud about the fruit, but in some cases may occur in the calyx and stem carities. This injury is rery commonly confused with that resulting from scab), Bordeatu injury and varjous other things. The presence of the characteristic bands as illustrated is a sure indication of frost injury.

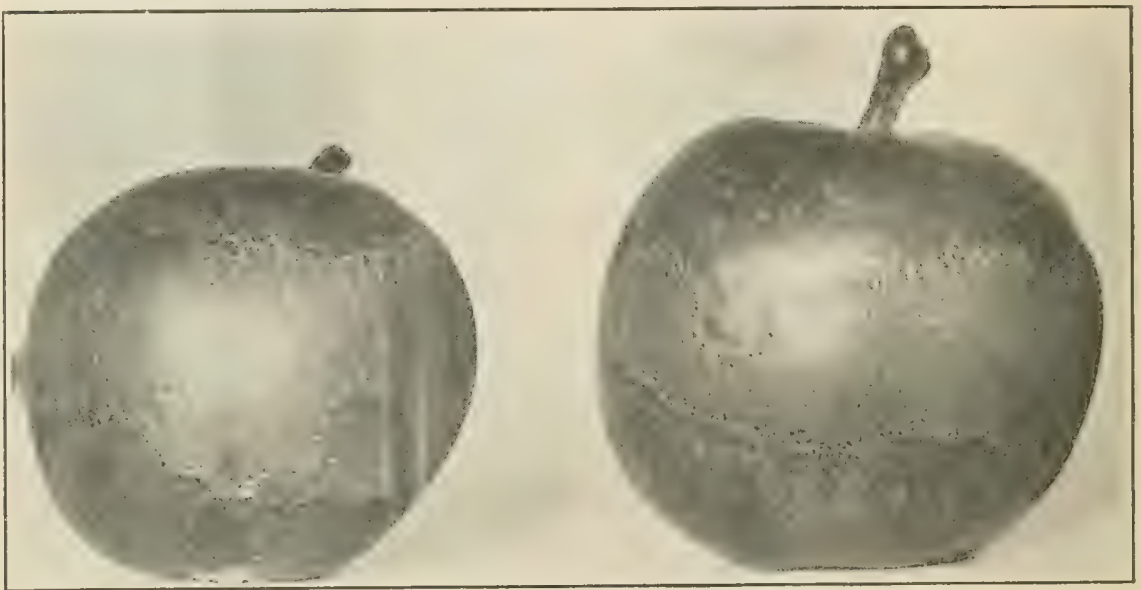

Fig. 47-Frost russet band on apples. (Original)

\section{LEAF INJURY.}

A f)e*uliar ('rumpling or blistering of the leaves of certain rarieties

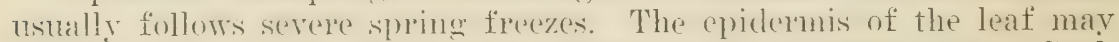
sepalate from the inside portion wherever these hlisters oecur. Such leaves are apt to turn yellow and drop very early in the season. 'This form of injury is not serious.

\section{SUSCEPTIBILITY OF VARIETIES.}

Some varieties of aproles will stand much more freezing than others. Again, some varteties will hlossom much later than others, thus reveaping a frost that would injure earlier hlossoming varieties. It is. therefore, wise for the orchardist who lives in sections of killine spring frosts to select the hardiest, and in some cases preference should be given to late hlooming varieties. As an illustration of this tact the Rome Beanty and Ralls apples blossom much later than the Ben Davis and Jonathan, consequently often escape injury when the latter named varieties are killed by a freeze coming about blossoming time. 


\section{FROST PROTECTION.}

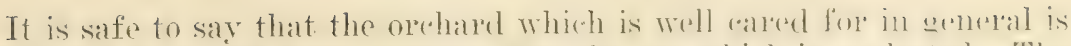

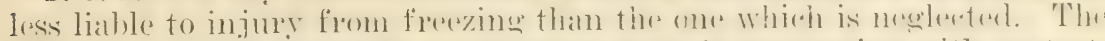
first point which should he emphasized. then, in commection with protecting the orcharel from killing frosts, is proper ane. Cultivation, prum-

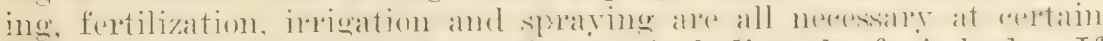
times for the best development of trees, including the fruit buds. If the buds ean an into the wintere in perefere romdition, there is every reasem to heliere that they will stand more than they would if devitalized because of unhealthy trees.

\section{SMUDGING.}

It has lome heen known that there is lifter dangere from killing forests

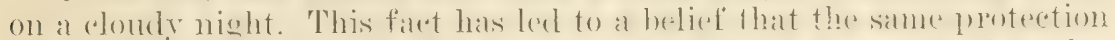

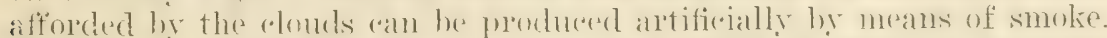

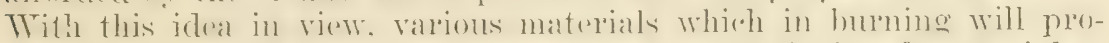
dure mueh smoke. have been burned in owchards during frosty nights. This method of potertion is known as smudeing. and is tast wiring

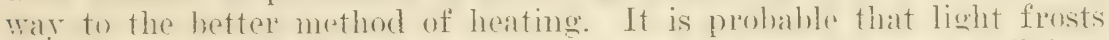

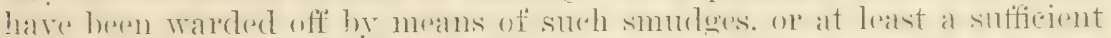

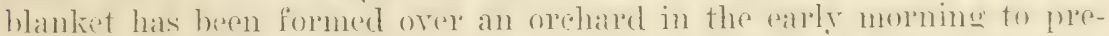

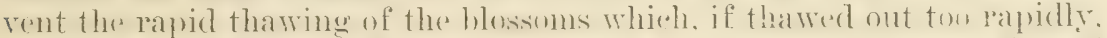
are sure to be killed. It is now thought that somelging in itsulf is of

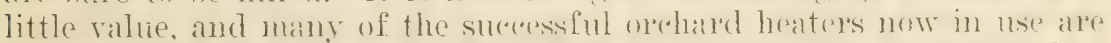
designed to nitilize as much of the linel as possible: the mome rompleste the combustion the better they are thought to be.

\section{ORCHARD HEATING.}

Thile there ares still many problems in amnection with orchard heat-

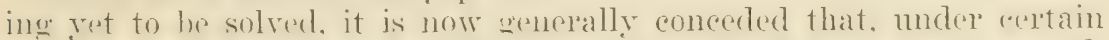
combitions, at least, a crop of fruit-citrus or deciduous-cam be saved.

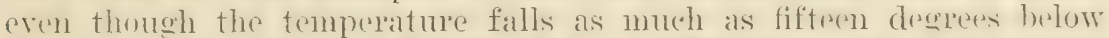
froming. During spring freozes of four different soasons in Colorado, tho writer had ahmudant opportmuity to study the various operations of the orehard heating husiness in time of action, and the effect of such heating in saving fruit. The ferst practical demonstration of what comld he accomplished was made in the spring of 1908. 'Three or four different parties had previously purchased some of the Bolton orchard heaters. which at that time were manufactmed in Califormia. By the 11:e of these small lard-pail pots, as they were called, which held about three quarts of oil, these men succeeded in saving a considerable amount of fruit. 'The demonstration was a perfect one, for only in the heated areas was there any fruit. Before this time there were orehards in ('alifornia where heaters had heen used. The Limomeira ('ompany had done considerable work along this line, and had nsed wire haskets for burning coal with more or less stzecess. The fact that it was possible to save a crop of fruit hy burning coal or oil in containers led to the making and patunting of a serat many types of heater's. practically any one of which will do the work, provided that the necessary anomnt of fuel is burned. Both coal and oil have given satistaction, but the latter is preferred by most orchardists. In California, where oil is so 
(heap) and coal is so high, it does not seem as though any one would be justified in purchasing coal heaters. It would not be wise to recommend any particular make of heater in this book. In general, the reservoir type of oil heatre is the most satisfactory. One can searcely afford to purchase heaters and other equipment for the work and then fail breanse of an insufficient supply of eil. Of comrse, it is possible to refill small heaters, or to have a reserve supply of them on hand, but such entails extra work and expense at time of heating when it is often hard to get enough help.

\section{PLACEMENT OF HEATERS IN ORCHARD.}

(One heatre for each tree is ordinarily used. These heaters are commonly placed in the enter of the rectangle formed by four trees.

\section{WHEN TO LIGHT.}

Firing shonld begin before the temperature has reached the danger print, the objecet being to keep it at a certain point rather than to let it drop below and then try to raise it again. For example, it is much easier to maintain a temperature of thirty-two dexrees when the outside temperature is twenty-five degrees than it is to raise it to thirty-two dewrees, after it has dropped down to twenty-five degrees. While fruit buds or blossoms may stand this temperature for a short time, it is never safe to let it get so cold.

\section{KEEP FIRING WELL AFTER SUNRISE.}

Iany a crop of fruit has beren lost because fuel played out, or because men became tired or carreless and let fires go down at daybreak. The coldest period is very often abont sumpise and the heaviest firing is necessary at this time.

\section{USE ONLY TESTED THERMOMETERS.}

To depend upon a twenty-five cent thermometer in the orchard heating business, when thousands of dollars are at stake, is inexcusable foolishness, and yet such has often been done. Nothing but reliable, tested thermumeters should be used in this important work. Several should be used and placed in different parts of the orehard, as there may be quite a temperature variation in a short distance. Electric alarms may be lised, but it is more satisfactory in actual practice to have reliable inen to wateh the thermometers and record temperatures every few minutes during the time of expected freeze.

\section{SUCCESS MEANS HARD WORK.}

Onr present knewledge of frost fighting with orehard heaters is not such that it ean be recommended under all conditions. With the temperatures that we usually have during the period of spring freezes in California, it is safe to say that the man who is willing to observe all the details, and who is not afraid of the hardest kind of work, will succeed. Not every man who has orehard heaters does, neither does every man who sprays make a suecess of that operation. Orchard heating, if it is dome at all, should be done rightly, or else all labor and expense may be thrown away. No one who is looking only for the easy jobs should have anything to do with this work. 


\section{SPRAYING THE APPLE.}

Whether it is generally beliered or not, it is nevertheless true that

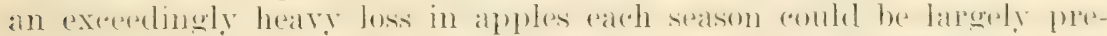
vented by propere spraving, and while there are many orehaldists whe spray intelligently and who get results, there are others who spray with little or no knowledge of the discases or inseret pests of their trees, and little more of the sprays that they are using. The first thing that the apple enower should do, if he would make the ereatest sureess of his business. is to familiarize himself with these pests and discases. It may seem to him that this is the work of an expert and he should not he expected to know anything about it. There is no question but that the expert's advice and help should be solicited, hut after all every one must know his own orchard, and with the help of such expert advice as he may be able to get, and through reading, it should be possible to learm evervthing that need be kinown about the inserets and diseases, so that intelligent methods may be used for their control.

There are too many apple growers spraying for colling moth, not

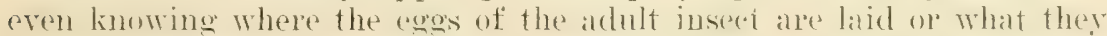
look like: there is too much spraying for the control of the various species of plant lice withont a thorongh knowledge of their life habits; and the same thing holds true in relation to apple seah, mildew and - other affections of the orchard. 'l'o illustrate, I have talked with seemingly intelligent growers whe thought that the arsemite of lead applied for the control of codling moth would kill the eggs. Such ignorance as this is, of course, not met with as a mle among our fruit growers. for it may be said to their great credit that there are no more intelligent people to be foumd in any other line of work; but one can not "oncepire of stuch lack of knowledge in regard to a pest upon which volumes have been written and with which every field expert in an apple section is familiar.

The writer is not a believer in promisenous hit or miss spraying. done nsually berause some one else is doing likewise, or berause some one said that the trees needed treatment. without any knowhorge of what was on them. The time to spray an apple orchard is when there is something on the trees that can be controlled by the spray. It is all very well to tak about preventive measures, but spraying an orchard for woolly aphis with a nicotine solution, or with some other contact spraty, will do no good for the control of this pest, unless it is actnally present. There can be no preventive effect in this case and yet we often hear people say: "Well, I had no pests on these trees but just sprayed to prevent them from "oming." Again, there could be no possible value of an arvenical spray for codling moth unless the pest was atually present in the orchard. There are isolated orchards of a ronsiderable age where this pest has never oceurred, and it would be the merest folly to attempt to prevent its coming by any spraying methods. There are also young orchards in sections where codling moth is present that may not be troubled for a few years, and there can be nothing aceomplished in spraying them until the moth arrives. It is always a good 
thing to keep ahead of the various pests and speray before they become too bad, but spraying costs money, so much that it is often done poorly in an attempt to save material, and too much emphasis can not be plared upon the nexesity for orchardists areruiring sufficient knowledge of the various pests and diseases, so that they may know when spraying need not be dome, or when it must he done in arder to hest protect the tres's or (rops. Berause of the lack of knowledge in this work many have advocated a reptain rourse of spratying to he given rach season regardless of condition of the ormatre or its previous reeord with respect to the pests. There may be sections where surh a rourse can he outlined and followed ont to advantage, but orchards differ as do individuals or eroups of individuals, and what one recunires may be absolutely mmenessiry for another, so after all the owner must study his orchard and learn to know for himself what is best for it.

Fabilure to rontrol the various pests of the orrhard when restain of them are present and when the right kind of an insectiride or fungiride is used, is more often due to lack of thoroughness in the application than to everything else. The writer has heard or ohardists, time and again, condemn certain sprays as heing poor when they themselves were to blane for the pon results attained. At one time an orehardist hat sprayed some youmg apple trees with Black Leaf " 40 ," $-1-1000$ for the control of the green aphis and when he got through the trees were still badly infested. He immediately complained that the material used was not gond. An investigation of the orchard showed that quite a large pereentage of the aphids had been killed but that there were still chough lift so that without further spraying nothing of value would have heen acomplished. For the purpose of a demonstration a few teess were resprayed with a dremehing rather than a light appliwation. In this ase practically one hundred per went of the liwe were killext. proving that the spray was gend hut that the methods of appliation were fanlty. When we stop to think that in cases of this kind the time and material is often 1 hrown away, whereas a little more care and a little greatr thoroughess, althongh it will cost more. will bring results, there is little excuse for hasty, careless work. While it is possibly not a good thing to adrocate as a general practice. it is monally better, from a financial standpoint, to spray one half of an orehard very thoroughy than to spray the whole thing for possilly the same rost and slight the work. In the first case a good crop of apples may be harrested from half the orchard, while in the second the loss may be total.

$\Lambda$ few years ago the writer sprayed a part of a very old apple orehard in southern Naryland, which had not received a spray for a long time, and possibly never. The apples for years past had dropped from fiungons and codling moth attack. In this case probably not over one third of the orchard was sprayed, by the use of a barrel pump and an $o x$ team. but for the first time in years it produced salable fruit which sold for a big price, but only the sprayed trees had good fruit. This Wals a most striking example of the possibility of protecting even a small part of an orchard by hearg spraying. When negligent orchard owner's can be made to see the value of heary splaying by starting in tirst on a small portion of the orehard for eronomy's sake, such work will often lead to the same kind of spraying over' large areas. 


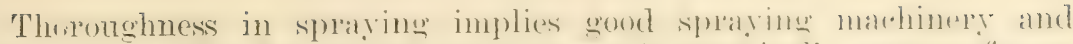

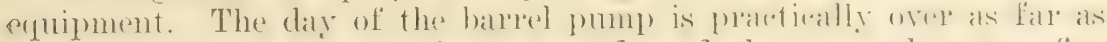
the commercial orchardist is concerned, and the man who owns five acres of apples needs a power sprayer. For a smaller acreage the barrel or tank pumps may still be used, but only by exereising the

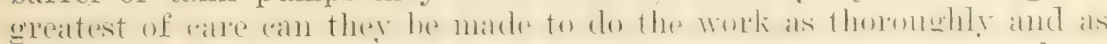
effectively as the power outfit. Our modern power sprayers have

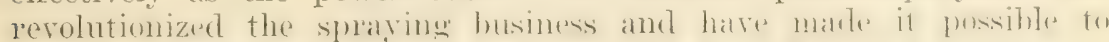

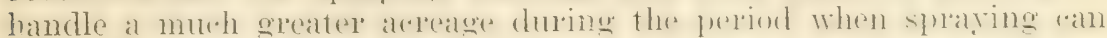
be most efferetively clone, and il any reitivism is fo lue mate of these

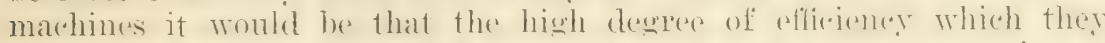
possess is sometimes depended mpon too much and the men, trusting to the machine to do it all, become careless. While it is true that with the high pressure which it is possible to attain trees may be very quickly sprayed, there is a tendency to hurry too much and the work is slighted.

Most of our power sprayers will maintain a pressure of two hun-

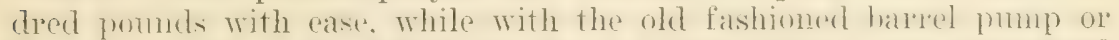
the latter tank pumpe eighty to one humdred pommels was rousidered gnod. Thorough work may he done with this lower presivure. hut the time required and the care necessary are greatly increased. It is,

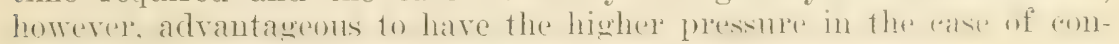
trol work for most of the insects of the apple.

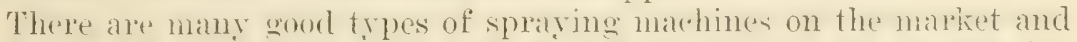
individual likes will determine which is to be purchased. I marhine should be equipped with two long lines of hose, at least fifty liset each.

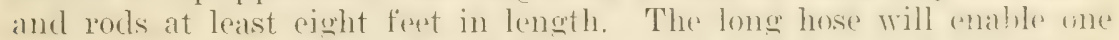

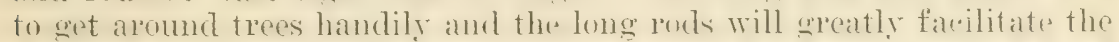
work of spraying. Of nimost importanoe in the equipment an eood nozzles. No machine can he repected to do the hest work without them.

\section{THE PIPING SYSTEM FOR SPRAYING.}

The smeat suress of the piping system used hy a fer ('aliformia orehard wowers indiuates the possibility of this latest method of distributing and applying the splays to om treses roming into general use. Cuder this sistem the portable tank with attarhed pump and gasoline engine is done away with and instead there is installed, at a convenient plare in the nerbel. stationary mixine tamks for the spray material and a system of pumps which forces the spray under pressiue through leads of half inch galvanized imon pipes buried at a comvenient depth and convenient intervals thronghont the orehoul. Standpipes for the attachment of the hose are comnerted to the muderomound srstem at such distances apalt as are necestary. The initial cost of such a system is. of course. comsiderable, and not every orchardist can afford jts installation. The oreat saving in time and labor during the work of spraying. the ability to spray an orchard when the ground is wet, and the possibility of so much more effectire work, make the srstem one to be recommended.

Instead of the pipes being placed permanently helow gromed as in the IIayward Reed system. nsed in his pear ordhard near Sacramento. a modification of this srstem may he used. At Watsonville the latter may be seen in operation and consists of suitable lengths of pipe which at the time of spraying are laid on the surface of the gromnd hetween 
the orrhated rows and the liquid spray is pumped thromgh them muder a high pressure from a central pumping plant located at a well which fonmishes the water supply. This system is said to work satisfactorily.

It is the firm belief of the writer that the future will see a great many of our better orehards sprayed hy the piping system. The wasoline power outfit, while we must recognize it as being an effective piece of machinery. has its drawhacks and its linnitations. An mugine

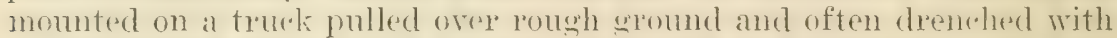
"austic sprays can not he kept in the very best working order and often the fluctuation in puessure is responsible for variable result in sprayjug. With the piphing sistem engines and pumps can he proterted in

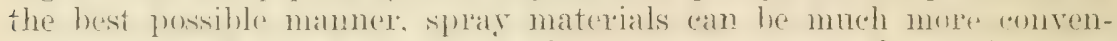
iently handlet, and a great deal of the present dread of spraving may

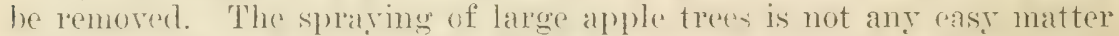
and repuires so muleh matexial that one powel spolayer is often inadequate to handle more than twenty-five ares, where spraying must of necessity be done quickly to gret the desired results. For instance. the calyx spray for adling moth must be dome during a rerion of little more than a week, if complete calyx control be assured. In a twenty-five acre apple orchard, with seventy trees to the acre, there would be seventern hundred and fifty treses. If they aro latere a two

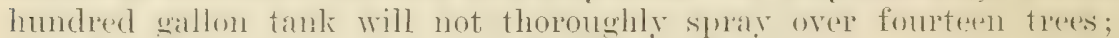
that is, one homdred and twenty-five tanks of spray womld he repuired for surh a twenty-five acere orehard. It is considered to be a woud day's work to put on ten tanks of spray, so twelve and one half days at this rate would be required to spray twenty-five acres. It is with a full realization of boing disputed and possibly ridienled for these figmes

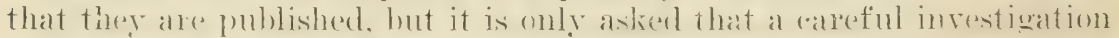
of the many failures to get results in sprayring he carefully mate by those who would disbelieve them. and a foll as mome of their alporoximate correctness is undoubted.

Before closing this chapter on spraying, a fer words, treating of

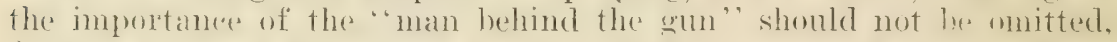
for the very hest equipment may be of little value with careless. ireesponsible men entrusted with the work of spraying. The most important men in a spraying arew are those who hold the rods and dirert the spray upon the trees. 'Their sight must be keen, they must be active and alert, and they can not be thinking of other thinges contimnally and do a goud job of sprayring, for this usually means the thomongh wetting of every portion of a tree; and how easy it is to slight the work just enough to defeat the object of the spray. Men who hold spray rods should he gifted with enough intelligence, at least, so that they could be made to know that upon the manner in which they do their work will depend the suceess or failume of the spraying operation.

Rexently while watrohing some Chinamen spray an orehard for the remtrol of colline moth. it was noticed that they had no ronerption of thomonghnes and apparently no realization of the important part they were playing in the work. Upon trying to explain to them that the work should he more thomoughly dome they seemed quite indignant that any one from the outside shomld attempt to show them anything. If this important job must be entrusted to the poorest among unskilled laborers, theil instruetions should at least he so (omplete that the work might not suffer. 


\section{INSECT PESTS OF THE APPLE.}

\section{CODLING MOTH.}

As failure to control the codling moth means failure to make a financial sueress of the apple husiness, a full disconsion of this most serious of all apple pests seems necessary in a work of this nature.

The ammal loss in fruit from this pest is tremendoms and comld we secure acentate figures they would be startline. Pradioally arery apple grower has at some time or other paid it toll in apples destroyed. and others have allowed their arops to go reall after yealr withont making any effort to save them. Despite the fact that it is so (oommon and so destructive a pest, it is one that is larewely meler one antrob and any orchardist who is willing to use brains in fighting it is gonng to moset with suceess. It is true. howerer. that the corlling moth sometimes gents so bad in a locality that one or two seastum of most metreful and heary spraving are needed to reduce its numbers to a point whepe entrol will

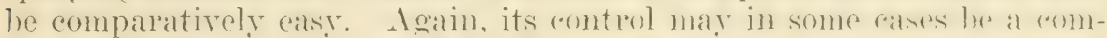
munity prohlem, where all must join in the fight if they would simered thenselves or proted their neighlors. It is not known just how liar the moths will thy. hut surely from an orehard on one side of a road to ome on the other. "Thus one may have to fight harder herause of the nexpligence of a neighbor who fails to spray.

\section{How the Pest Spends the Winter.}

A knowledge of the wintering habits of an insect is sometimes a valuable thing in rommertion with its rontrol. In this atse we have a pest that winters in such a way that something. hut not all. may he done toward its eontrol during the winter or dormant season. After the full grown second brood larvar leave the apples in the fall or winter they secrete themselves under the loose hark of trees in the orehard. in cracks between boards in packing or storage houses. in fact almost anwwhere that they can find hiding places. As a majority of the womy apples usually fall to the ground before picking time, the worms in them that may eseape ean rearlily peach trees where hiding places may lw fomd. Very frequently, horever, they leave the apples while they are still hanging to the trees, and crawl down the limbs and trunk until suitable quarters are diseovered. When such are found the lorver immediately begin the construetion of little areoons of silk, which when completed form a protection against the weather and enemies that might prey upon them. In this eocoon they remain as full grotrn apple worms or larve throughout the entire winter season, and never ean they be found in any other stage during this time. Br seraping off the loose bats on old trees, in particular, frequently large numbers of these hibermating larve may be destroyed. Such should always be done when an attempt is being made to control the pest in an orehard or collection of orehards, where spraying has been neglected until the eodling moth has become so abundant as to make spraying work more or less ineffective. 
The natural mortality dure to weathere conditions during the winter time is sometimes great, but raries from sealson to season. The numbers that survive until spring to develop into moths have an important hareing on the ease or difficulty with which this insert mar be controlled. If a winter sealson is such that seventy-five per eent of the worms which lesem hibermation in the fall transforme the females to lay uges in the spring. it would he expected that a much more serious condition would result, providing no spraying were done, than if only ten per cent had lived through. As the number of larve that are present in the spring will determine larely the number of applications of spray that are nexessily. and ats al superabundance may meam the loss of a great many apples. mo matter how carefully the work of spraying is dome. too muet attelition cannot be paid to destroying the larve during the winter seatson. beneath bands put on trees as traps in the summer, and in every way possible to reduce their numbers to the minimum.

\section{The Pupal Stage.}

When the warm weather of spring comes on the larva which have survived the winter hegin to pupate, and in the rocoons may be fomd little hown, footless, quiescent creatures, not able to move ahout, and aside from a slight movement of the portion corresponding to the aldomen of the adult which will soon emeree, they are immohile. This stage may last several weeks in the spring, but in the case of first brood pupar it arerages ahout two weeks. From this stage there develops the matme winged moths the females of which, after mating, hegin egor laying.

\section{The Moth Stage.}

No orehardist who grows apples can reasonaloly find any exemse for not knowing the appearance of the codling moth, and yet there are those who are apt to mistake almost any kind of a common eutworm moth for this destructive species. A few mature larve or pupe, collected and put in a pastehoard box auy time during the spring or summer season, will develop into moths and the characteristic appearance may then be noted. They are gray in rolor with distinet yellowish, ahmost gold colorer spots near the tips of fore wings and a wing expanse of not over three fourths of an inch. The characteristic yellow markings make this species readily distinguishable from practically all others, and yet we find men who should know hetter, trapping moths by lights. mostly entworm species, and daiming that they are destroying the codling noths.

\section{The Egg Stage.}

Contrary to the general opinion codling moth eggs are not hard to find when one learns what they look like and where to look for them. They are laid singly on the foliage or fruit, and rarely on the twigs. If found on the former, in practically every case they will be found on the upper or smooth surface of a leaf and almost always close to an apple or cluster of apples. The moths seem to possess an instinct which pompts them to lay these eggs where the little worms, upon hatching from them, will have little trouble in locating some of their food-the fruit. In shape the egess are almost eireular and rery flat, adhering closely to the surface of a leaf, or apple. The diameter is about that of the head of an ordinary pin. On the surface there is more or less 
of a winkled or roughened appearance. 'The color at first is creamy white. In a few days - three or four - a reddish ring may be plainly

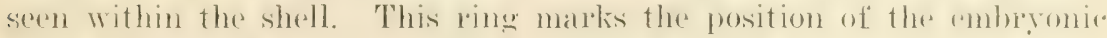
larva dereloping within. Before hatching, which nommally takes platep about the seventh day, there may be seen a black spot near one side of the ene. This spot is simply the hack head of the little worm within and indirates that hatching time has arrived. The thin white shells of

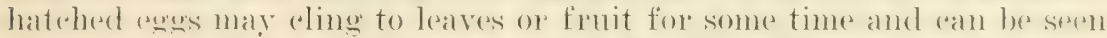
in any orellated where codling moth is at all bad, during the summer seasoll.

\section{Control.}

A very large per cent of the first brood larva begin feeding in the calyx wel of the apple, the number varyine somewhat with seasons, locality and valety and estimated hy seientific workers to be from serenty-tive to ninety-five per cent of the total brood. In the case of the serond hrood quite a large pereentage also enters the calyx, hut as the fruit is large when they come on there is a better chance for the liftle worms to enter alsewhere, and quite a rood many bore into the frut through the stem cavity or somewhere on the side. This fart, rompled with the important one hearing on it, that sprays must he applied to coat the entire surfaces of the apples, makes it of the utmost importance to devote every energy toward killing practically the entire first brood, so that the second as a consequence must be small.

The lact that so great a pereentage of the first brood of worms seeks the calyx as soom as hatched has resulted in the standard method of control for this pest. viz: a heavy spraying with some arsenical insecticide when the petals are practically all off and before the calyx lobes have closed.

\section{Spray to Use.}

The most satisfartory and widely used arsenical spray for codling moth is arsenate of lead. It is made in both the paste and powdered form. the first mentioned being used more generally than the second. Other al'sentrals that may be substituted for the arsenate of lead are arsenite of zinc and Paris green. The arsenite of zine is a good poison. hut has mot wiren general satisfaction because of its liability to burn fruit and foliage. It is. however, used considerably for the first or calyx spraying. as little damage seems to result from its application at this rime. Later applications are dangerous. Paris green, when substituted for these other's, should be applied with mille of lime in small ruantities. to prevent burning:

\section{Strength of Spray.}

Alsenate of lead in the paste form should contain from 12 to 17 pere cent arsenic oxide. Three or four pounds of this paste to 10 () wallons of water is of sufficient strength to kill the larvar. It is probahly a good plan to inrerase the strength somewhat for the later sprayings, applied for the purpose of coating the fruit. The powdered form of lead arsenate contains about donble the amount of arsenic oxide per pound. hence only one half as much is necessary for a given amount of water. The same is true of zinc arsenite. Paris ereen should be used at the strength of one and one half pounds to 200 gallons of water, with the addition of about ten pounds of strained milk of lime. 
The strength of spray to use as given in this publication is less than the manufacturers of arsenicals usually recommend. It has been proven by careful experiments that the amount given is ample and special emphasis should be laid upon the necessity of putting the spray where it belongs. It matters not how strong a spray is used, it can do no good unless it is placed where the worms will feed upon it. Time and again in the writer's experience have orehardists been known to condemn the spray as faulty, when they themselves were to blame beraluse of their careless methods of application.

\section{How to Apply Spray.}

It seems almost superfluous to say anything about how to apply a spray, but after all there is much to learn before the beginner can become expert. The tendeney is always to use too little spray, thus slighting the work. In making the application for codling moth, thoroughness is the keynote to success and anything that will bring it about is desirable.

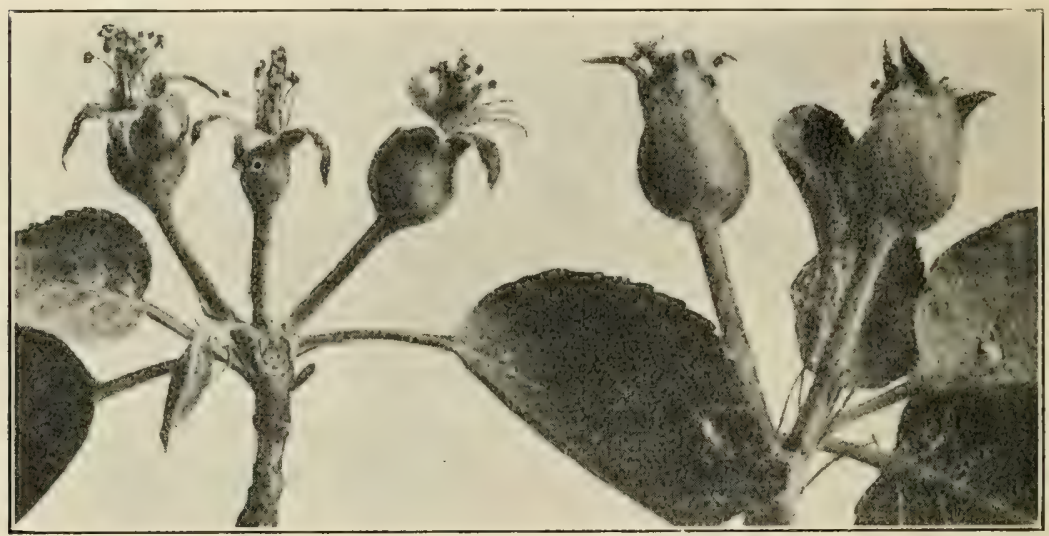

Fig. 4S.-Apples on the left just right to spray; ralvees are ton nearly closed on apples shown on right for the most effective work. (After Quaintance)

Only the most careful help should he engaged, and men should be trained to do the work so that, when a tree is finished, they know that they have sprayed it from every angle. This necessitates walking entirely around a tree. Spraying that is done from one side only eannot be thorough and is of little real value. There is a tendency for sprayers to hold the nozzle too close to the limbs and, as a consequence, the tips are very often missed. While a tree must be sprayed on the inside, it must not be neglected on the outside, and by holding the nozzle two or three feet back from the extremities of the longest branches, as the tree is encircled during spraying, there can be little of the surface missed. In all spraying work for coddling moth the apparatus should be of the best. Long rods with forty-five degree angles on the tips, and a driving spray with high pressure, will greatly facilitate the work.

\section{First Spraying.}

There are few orchardists who have had experience in spraying for the control of this troublesome insect the country over, who will discount the value of the calyx spray. This must be applied before the calyx 
cups close and fortunately there is a period of a week or more with most varieties of apples, after the blossoms fall, when the calyces are open, and a few rare cases where they nevere close tight. Tarieties, soil and climatic condifons bring ahout this variation. Knowing that a larew pereentage of the first brood worms enter by way of the calyx, and that every one that escapes being killed by the first spraly and derelops inte a moth of the second brood - which if a female may lay seventy-five eggs to hatch into second brood worms-we camnot he too cal'etul in making the first application. The aim should be to fill every (ady coup with the liquid, which, upon evaporating, will leave a deposit of insoluble arsenic to remain in and protect the apple throughout the entire season. Every sprayer should test the efficiency of his work by examining trees, after he thinks they have been well sprayed, and see it there are any calyces that are dry and have not been touched by the spray. If this is done one will soon realize how exceedingly hard it is to fill every cup. As many of the blossoms point upward. spraying from a tower is often practiced and is a decided advantage when trees are large.

As varieties of apples differ as to the time of hlomming. there is frequently trouble experienced in extting the spray on trees of rertain kinds at the proper time. This trouble is preatly exagrerated in our older orchards, where many varieties have heen planted and where there mar be great differences in their blomming habits. It is not serions in orchards of lare blocks of a few varieties. for those that bloom first can be spraved first and the others will probably be in good condition immediately afterwards. Climatic conditions are sometimes smeh that the blossoms of a given variety do not come out evenly. Wheresuch is the (ase a double application should be made for the calyx in order that the createst efficiency may result. If this repeat spray is found to be necessary it should be applied from a week to ten days after the first or regular calyx splay, when the majority of the hlossoms have fallen.

\section{Second Spraying.}

Alrady two sprayings have been mentioned, but in actual pracotices the second calyx application is not usually fomd to be necessary. The regular second application, which it is never safe to omit if codling moth is at all hard to control, should be made about three weeks after the first. At this time there may still be a few of the calyces open. and it will have some value as a calvx spray. Its ehief value lies in the fact that it is applied at a time when the worms are beginning their work, and many may be killed on the sides of little apples which will, at this time, receive a coating of the arsenical.

\section{Third Spraying.}

A third application two weeks after the second is often desirable to supplement the work of the latter. The little apples grow very rapidly when they once become set, and diffeulty is experienced in keeping a protecting coat of spray over a large part of the surface. As the apples grow, the individual particles of arsenate of lead become correspondingly farther apart and the worms have a better chance to gain entrance. The third regular application will be put on at a time when the hatching of first brood worms is about at its maximum; hence it is a very desirable spray during seasons of an abundance of codling moth. 


\section{Fourth Spraying.}

Generally speaking. theres sprays are sufficient to enentrol the codling moth, provided that they have been rightly timed and thoroughly applied. The writer has known of many cases, however, of serious infestation where this sploty and another following eomld be made to pay.

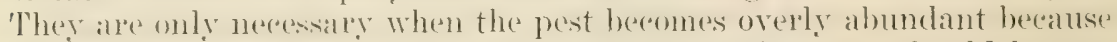

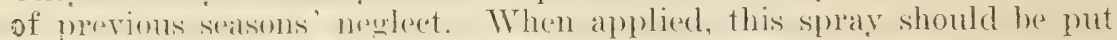
on about fifty da!s after the second rexular application. The latter was put on about the time when the first brood of egges were begimning to hatch, and as the second will begin approximately fifty days from this time, of in of her words, as it takes the insect seven weeks to mudergo all its transtormations in a brond, the spray is timed to the hatching of the first of the second brood.

\section{Fifth Spraying.}

This applieation is simply to supplement the fourth and should be applied about two weeks later. Its use will insure a better coating of lead aresuate on the apples and thus hring about areatere efficiency in killing worms.

\section{Other Control Measures.}

(ienerally speaking, careful attention to sporaying will bring about complete control of codling moth. Conditions may hecome such through neglect $(1)^{2}$ otherwise, that something ase must be done to reduce the numbers of the pest sutficiently for effective spraying. To illustrate, the writer onces sprayod an orchard where colling moth was so abundant that one troe lift without spraying had only seventeen pere cent of the fruit somme at pieking time. Five sprayings in this orehard, all heavily and callefully done. Were necessary, hut even after all this spraying a considerable pereentage of the apples were actually wormy, or were speched whepe worms had attempted to eat in and were killed. In such rases as this, cloth bands of burlap or other material, placed about the trunks of the trees about June first and removed, and all worms underneath killed every ten days until apples are picked. would result in such a reduction of the worms that the second hrood would be less troublesome and fewer worms would go into winter quarters. Burlap bands should be of three thicknesses, about five inches wide, and may be held in place with thumb tacks.

Removal of rough bark on old trunks is always desirable, as many larva hibernate underneath.

Packing-houses frequently serve as harhoring places for worms, which crawl from apples brought in for packing or storage. These may find cracks between boards, boxes or rublish of any kind in which to spin coconns and palss the winter. Screening of such houses to prevent the exit of moths in the spring is sometimes desirable.

\section{APHIDS AFFECTING THE APPLE.}

\section{The Woolly Aphis of the Apple.}

(Eriosoma lanigera.)

This very common and destructive pest is so well known to every applo sowe that it hardly serms necessary to go into details regarding it. Not only is it common, but it is also one of our hardest pests to 
control. Its name is derived from the fact that the purplish body of the adult louse is covered with a wool-like, waxy excretion. When

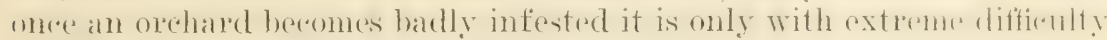
that this insect may be checked in its ravages.

The woolly aphis works both above and below ground. 'The damage to the roots consists in a roughening or knotting of the surface, with

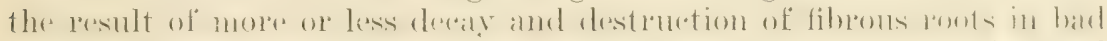
cases. The winter season is spent by the lice both on the branches and trunks above ground and on the roots below the surface. During the

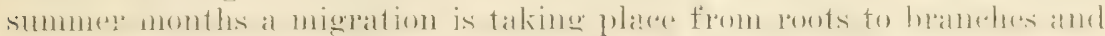
vice versal, throughout the time of antive freding. with usmally a more general migration in the early spring and late fall. One winged generation develops during a season, and this in the fall. These winged lice are all viviparous females and give birth to sexual males and

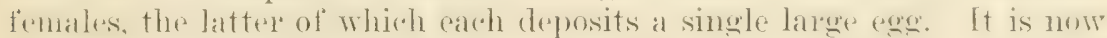
thomght that migration takes place from the apple to the whe and that

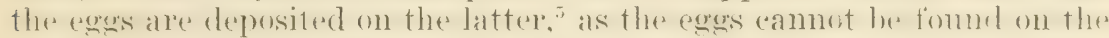
al) ple trees, though seareh has heen made for them there time and again.

\section{Control.}

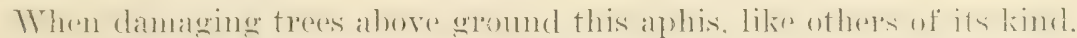
may be readily killed by a spray of Black Leaf " 40 " and soap, using

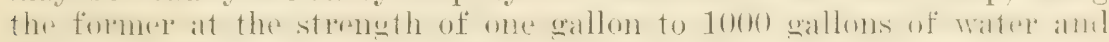
about 5 pounds of soap to 100 gallons of water. They are not at all

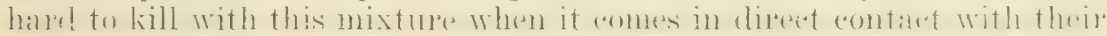

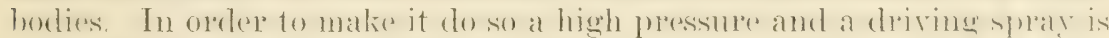

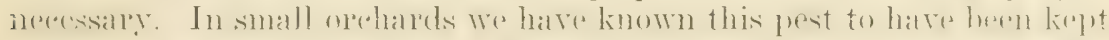
in check, in the early spring, hy the application of coal oil hy means of a brush, to colouies located in racks, knot holes, etc., as they rolonized after migrating from the roots.

Underground treatment has been on the whole unsatisfactory. In the case of small trees, tobacco dust or a spray of Black Leaf " 40 " and

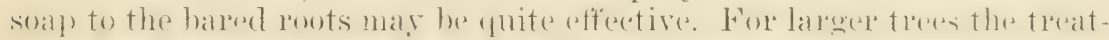
ment is not practioal, as the aphirle follow the poots to their axtremitios. especially if they are shallow.

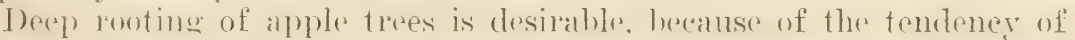
this pest to attack the shallow roots most serepely, as well as for other good reasons.

\section{Resistant Varieties.}

Sone varieties of trees possess more or less resistance to the attack of woully aphis. The Northern sipy probably is more nearly immume than any other variety and for that reason the roots are very often used for propagating purposes.

\section{Natural Enemies.}

Lacewing flies, syrphid flies, and ladybird heetles frequently ken this pest in check. There is no more effective predaceous enemy in this "aste than the lacewings, and exceedingly bad infestations orer latege areas have heen seen destroyed in a comple of weeks time hy them. A little internal parasite, aphe finus mali, is sometimes a considerable faretor in its control.

\footnotetext{
see Bul. 217, Maine Exp. Sta.-Edith M. Patch.
} 


\section{The Green Apple Aphis.}

(Alphis pomi.)

The little shiny black, oblong exges on the new growth of apple twigs during the winter season, have been seen by practically every apple orchardist. These are the exes of the wreen apple aphis. laid there by a small gereen plant louse in the fall. As the buds begin to open in the sprome these exes hateh and the little date green colored lice immediately bexin feeding upon the new erowth. These first spring lice. which hatched from the orerwintering reges, are known as stem-mothers. When they become mature after a romple of weeks of feeding they give birtlı to living young of a second generation. These in turn do likewise, and a number of generations are developed throughont the season. Many individuals after the second generation develcp wings, and thus may thy about from tree to tree and orehard to orchard, spreading the infestation. In the fall true males and females are developed. These are wingless and may be distinguished from the agande forms by their color. which is rellow instead of dark areen. The females doposit the egges previously described. Their injury is done principally to the leaves. although in bad cases the fruit and even tender twigs may be attacked. The sap is sucked from the parts upon which feeding takes place. A curling of the leaves is a good sign of the presence of this insect. Ints feed abundantly upon the excrement or honeydew, and are always present in ammoying numbers when infestation ocours. P(arr, quince and hawthorn are subject to attack, as well as the apple.

A thorough spraying with Black Iseaf " 40 " and soap, at the strength recommended for woolly aphis, or distillate or oil emulsion in the sprimer when eggs are hatching, is effective. Any of these sprays may be used later in the season to advantage. Lime sulphur, 1 part to 10 parts of water, is supposed to possess some virtue as a dormant spray for the exys. Observations made in Colorado hy the writer did not justify its uses. except when it was put on just as the eggs were beginning to hatch early in the spring. If applied before hatching time it may lave some virtue, but results attained have been variable.

\section{The Purple Apple Aphis.}

(Aphis sonbi, )

This is without doubt the most serious aphid pest of the apple, as far as their effect upon the fruit is concerned. Like the green apple aphis. they spend the winter in the form of small black exos on apple trees. which hatch very early in the spring. Almost before the buds have begun to swell pereeptibly, the little blackish colored lice may be seen hanging on the outside waiting for them to open. Feeding begins immesdiately upon the bursting of the buds. After about three weetss time these stem-mothers have besome mature and reproduction without exeslaying begins.

The second generation is purplish in color, the lices being covered with a powdery secoetion. Feeding takes place very generally on the leaves. cose to the colusters of youme apples, and more ralely on the apples themselves, which are injured to such an extent that they become stunted and not only fail fo mature, but are distorted so badly that the rarese may not be recognizable. 
During the month of June, according to O. E. Bremner, wings are developed and a migration takes plate from the apple to some intermes-

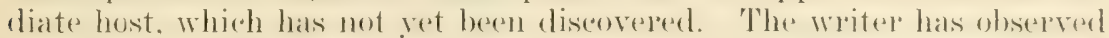
this habit of the louse in Colorado, and H. F. Wilson reports that a similar migration takes place in Oregon. Mr. Bremmer. who has dome more work on this species in California than any one else, states that he has found the aphis on careless weed (Amarantus retroflexus), but does not report having found it colonizing or feeding upon this plant.

In the fall winged lice peturn to the apple and produce sexual forms, the females of which lay eggs for the perpetuation of the species.

\section{Control.}

The rely early hatrohing of the exes makes it mecossally that a spring treatment for this pest be made accordingly. The writer has found hatched lices of this speceies in February in Colorado, and there are no douht seasons in (alifomia when just as ealy hatrome would take place. Professor Wilson peports finding them in orexon as early as Felnuary 20d, in 1912. The stem-mothers become quite resistant to

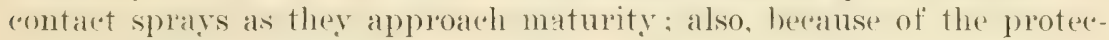
tion of toliage at this time, spraying is often done with very poor surcess. The ideal time to spray is just as the egers ate through hatching. and while no date can be set, the time will conform colosely to that of the swelling of the buds. Such work should not be neglected until the blossoms begin to appear, as this is too late for the best results.

Professor. Wilson recommends an early spring treatment with a combination of lime sulphur and IBlack Leaf ' to.', Mr. Bremmer has had splendid sucess with fall treatments when the sexual forms of the lice ale present. using a crude oil cmulsion formula which is male as follows:

"Place 88 gallons of water in the spray tank and add 1 to 2 vallonis liquid soap, depending on the sofituess of the water used. diluted with about an equal amount of water. Agitate until thoromghly mixed and then with the agitator rumning add 10 gallons of crinde oil.",

\section{A second formula recommended by Mr. Bremner follows:}

"Dissolve 10 pounds of whale oil soap in not less than 10 gallons of water by boiling; slice the soap and it will dissolve more quickly. Place this in the spray tank, which should contain about 10 gallons of water. Thoroughly agitate and add enough water to make 90 wallons. then add 2 pounds of caustic soda (aoncentrated lies), dissolved in water. With the agitator rumning add 10 gallons of coude oil slowly."

Either formula is said to be effective and speraying should be done about Sorember 25th in the Sebastopol section. where Mr. Bremmer did his work.

\section{Other Species of Apple Plant Lice.}

The thres species already treated are the only ones of any importance that have been taken on apple in ("alifornia. O'“assionally other species are found in limited numbers. C. P. Gillette and E. P. Taylor, in B3ul. 1:3:3 of the colorado Experiment Station, and II. F. Wilson in the Binmial ('rop Pest and Ilortiendtural Report, 1911-1912, of the Oregon 
Agrieultural ('ollege and Experinent Station, mention the European grain aphis (Aphis arence) and the clover aphis (Aphis balir ri) as being of more or less importance. These species are not commonly found on apple in California. The melon aphis (Aphis genssypii) and the sweet rover aphis (Aphis modicuginis) are ocoassionally taken on apple. but are never serious.

\section{MISCELLANEOUS APPLE PESTS. \\ Apple Tree Leaf-Hopper. \\ (Empoasca mati.)}

Infested leaves appeat more or less mottled with whitish marlingsi similan to those injured by mites. An examination of such latres will cliselose the fard that little white bodied, sucking inserets are feeding mulerneath. These hatch from exges laid in the bark of yome growth. Trings are dereloped during the season and upon the slightest disturbance to the trees the inserets take flight, and when infestation is bar swarms of them may be seen in the air.

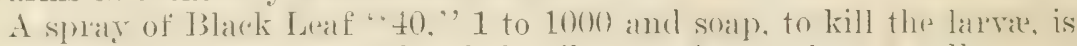

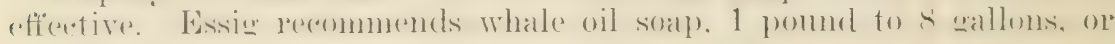
oll emulsions.

\section{San Jose Scale.}

(Aspidiotus perniciosus.)

This scale inseret is more commonly found than any oflese on apple trees in california. It is rery easily recognized, beanuse of the fant that it causes small red spots to appear on the bark and fruit wherever it

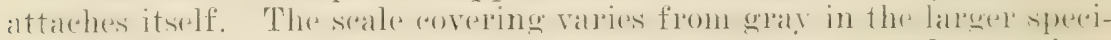
mens to sooty black in the smaller. Underneath these scale coverings may he seen the little rellow bodies of the insects themselves. Which live by sucking sapt from the bark through their little beaks by which they are attached to the twigs. The pest winters in different stages of growth. It may he entrolled by a spray of either lime-sulphur or an oil emulsion during the dormant season.

\section{Oyster Shell Scale.}

(Lepidosaphes umini.)

This sealle was so named herause of the falet that the "overing is shalped somewhat like an oyster shell. During the winter season an examination will disclose the faret that there are a great mumber of little white egess underneath the seale coverings. These hatch in the early spring, the little seales immediately attaching themselves either to the folliage or bark, where feediug hegins. Lime-sulphur is reommendect as a spray during the dormant season to control this insect. It is also readily held in check hy means of oil emulsion sprays, just as the egges are hatehing in the spring.

\section{The Scurfy Scale.}

(Chionaspis furfura.)

This spredes may be distinguished by the dirty white seale corerings on the bark. Underneath these may be seen the purple bodies of the insects, or eggs of the same color.

Dormant sprays of either lime-sulphur or oil emulsions are used with success. 


\section{Apple Tree Leaf Roller.}

(Archips argyrospila.)

In The Monthy Bulletin, Vol. II, No. 9, of the Sitate Commission of

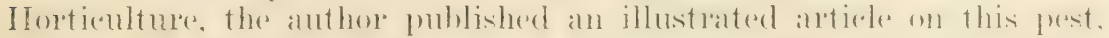

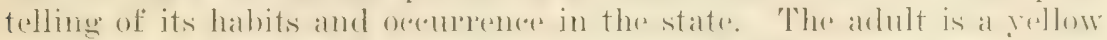
moth about the size of the colline moth. With white markines. Fens

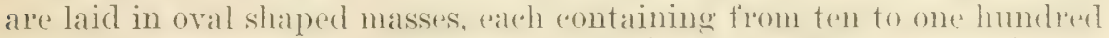
and fifty eggs, on the limbs and trunk in July. 'T'hese hatch in the spring as huds are opening and the little whitish lanve inmediately

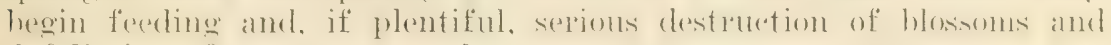
defoliation of trees may result.

When full grown or ahout three fourths inch in length the laxvar? pupate, mostly in the polled leaves, though frequently alsewhere.

Complete control may be brought about by an early spring application of either a miscihle oil spray or coucte oil emulsion to kill the exges.

\section{Apple Tree Tent Caterpillars.}

(Malcosoma disstria and Malacosoma americana.)

'The former is the common species in California. Both may be recognized hy the large wel) tents which ale mate where the colonies feed, aftex hatching from egges which were deposited hy the moths on

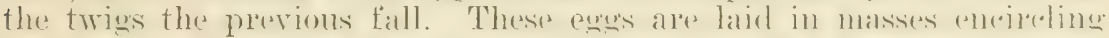

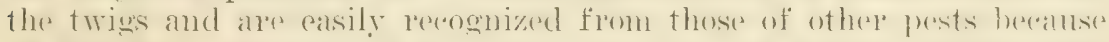
of this fact. Feeding nsually takes place hy the hairy waterpillats in quite definite areas within and surrounding the tents.

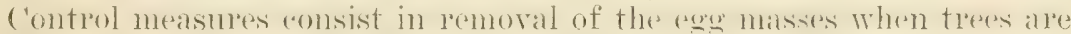
heing yrumed in the dormant season, destruction of the web tunts with the larvie enclosed in the early morning or late in the evening, and arsenical sprays. Where spraying is done to control codling moth this pest is also satisfactorily controlled.

\section{Tussock Moth.}

(Hemerocampa vetusta.)

Considerable injury is sometimes done to young apples by tussock moth larve, and mature fruits are often seen in the parking-houses which show the scars due to this early injury.

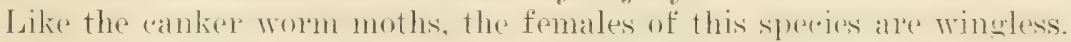
The winter season is spent on the trees in the egg stage, in masses protected by the cocoons from which the female moths emerged.

The larve are quite resistant to an arsenate of lead spray, but arsenite of zinc is said to be somewhat more effective. Sticky bands are often used ahout the trunks of the trees to keep larva. which are shaken to the ground by jarring, from crawling back.

\section{Spring and Fall Canker Worms.}

(Paleacrita vernatu and Alsophilu pometaria.)

These two species of moths are very similar in appearance, both hring wingless and drpositing their eggs on almost any portion of the tree after crawling up the trunk. The larva are some of the so-called

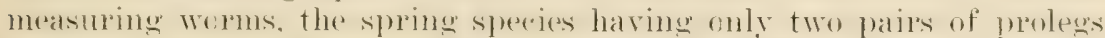
while the fall species has three. Otherwise they are very similar. There is only one generation of each during the season. The spring 
species winters over in the pupal stage in the soil while the fall species spends the winter on the trees in the egg stage. The fact that the female moths are wingless and can not fly into the trees makes it possible to control this pest perfectly hy means of a band of some sticky preparation applied to the trunlis. Arsenate of lead as used for the codling moth is of some value in controlling it. Black Leaf " 40 " at the strength of 1 part to $10(0)$ parts of water has also been successfully used for both the spring and fall species.

\section{The Red-Humped Caterpillar.}

(Schizura concinna.)

The foilage of the apple is frequently attarked by commmnistice caterpillars. with red heads and laree red himps on the first segment of the abdomen. Many prominent back spines along with this peculiar hump) render the speceies very comspicuous. The adult is a brownish moth, which lays its eggs on the leaves. The winter is spent in the pupal stage in the ground.

Control measures consist of picking the caterpillats from the trees and spraying with arsenate of lead.

\section{Climbing Cutworms.}

Quite frequently in the early spring, huds of young apple trees are hollowed out by some species of climbing cutworm, of which there are several. This trouble is msually worse on sanciy soil than on any other kind. Damage from this pest may be eliminated by meams of cotton batting bands tied about the trees, over which the worms are mable to crawl. The method of using a cotton batting band is as follows: Take a band of the batting about three inches wide, and of sufficent length to go around the tree. After placing about the trunk, tie it near the bottom with a piece of trine. pulling the top portion downward, thus forming a collar which the worms do not penetrate. During the day time they may often be found in the soil near the crowns of the trees.

\section{Flat-Headed Apple-Tree Borer.}

(Chrysobothris femorata.)

Sun scalded or otherwise injured trees are liable to attack from this borer. The adult is a that metallic colored beetle, which lays its eggs on the treess. Tpon hatehing from these exos the footless larvere with body widened in front and tapering to the posterior extremity, feed in the sapwood, often completely cirdling a tres. Quite frecuently burrowing into the heartwood takes place.

There is no practical means of control. Preventive measures consist entirely of keeping trees in a thrifty growing condition.

\section{The Brown Mite.}

(Bryobia pratensis.)

While theres are of here mites that oceasionally feed on apple foliage. this speedes is the one most commonly foumd. 'The little red eages are deposited in the crotehes and frequently about the buds of trees during the fall or late summer season. These remain monatehed thromghout the winter. In the early spering, as the foliage begins to come out, the eggs hateh and the littlo mites, which are red at first, begin feeding 
almost immediately. At this time they have only six legs, the fourth latir beine developed as soon as they moult for the first time and the color changes from red to greenish. 'There are several generations during the summer season. hut uswally the mites do not lesome abumbant enough to seriously damage the apple trees.

Lime-sulphur, applied at the strength of 1 part to 10 parts of water. during the dormant seasom, just hefore the huds hegin to swell, is an effective remedy. Eithere atomic or milled sulphur, during the summer season while feeding is going on, is also valuable in controlling it. Sulphur in any form is a good mite remedy as a general rule.

\section{Blister Mite.}

(Eriophyes pyri.)

While this is primarily a pear pest it is sometimes found injuring apple foliage, also, to a considerable extent. It may he recognized by the blister-like patches on the surface of the leaves. 'l'he winter season is spent monder the bud scales of both apple and pear. In the early sprine the mites leave their hibernating yourters. the females depesiting eges in the leaves, from which hateh the tiny larva, which inmediately begin foeding and produce the characeteristice appearance alveady mentioned. This pest may be eontrolled hy an application of lime-sulphur just as the huds are beginning to open in the early spring. 
CHAPTER XV.

\section{DISEASES OF THE APPLE.}

\section{BLIGHT.}

(Bacillus amylovorns)

This distase afterels some varietios of the apple as barlly als jt does the peatr, and when trees in au orchard berome affected the same remedial measures must he applied as in the "ase of the latter, vi\% pruning out all diseased woud in roots. trunks and hranches, being sure to ent well helow where any signs of the disease are noticed; and callefully disinferting all tools and rut surfaces with oorlosive sublinate solution, 1 to 1000 , after every cut.

\section{OAK ROOT FUNGUS.}

(Armiliaria mellea.)

Quite frequently apple trees are found rotted in the roots and at the crown hy this serous discase. The writer has in mind one orehard visited early last suring. Where tree after trese was diseaser with this fongus. ()aks had been growing on the land previous to the time of apple tree planting and the stmmps were still standing thromehout the aroharel in many plares. Nurrounding these stumps a number of trees Were frepuently fomed to be affereted and ereat masses of toadstools, the fruting hodies of the fungus, Were growing ahout the stmmps and apple trees. 'There is no cure known for this disease.

\section{APPLE SCAB.}

(Venturia incequalis.)

'The very destructive and commonly distributed disease known as apple sab is familiar to pratically arery apple grower, and during certain seasons a heary loss is sustained from it, if nothing in the way of spraying is done to control the fungus.

It has a preference for certain varieties, others being more or less resistant. The Yellow Newtown is one of the most susceptible to attack, and spraying of orchards consisting of this variety should never be neglected in sertions where scah is prevalent. The Esopus is also very susceptible in California. as well as many other varieties that might be mentioned. Locality of course, has rousiderable influence upon this troulde, and in general the high altitude orchards in Caliturnia suffer most.

Fig. 49 illustrates the appearance of this disease as it oceurs on the fruit, the well defined, nayish seabby patehes, more or less ronghened where the skin has been broken through. heing characteristio of the advanced stage of the disease.

This discase is due to a fungous organism which winters on the tree and on fallen foliage. The plowing under of the leaves, hefore the spores have a chance to get into the trees in the spring, is one of the important things in connection with its control. 
spraying with some good fingicide must not he menlected. An early spring application of lime-sulphur at the dormant strength, or of Bordeatex mixture, applied as the huds are swellinge. should be mate. This should he followed hy later applications, which may he rombined

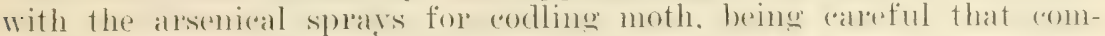
fatible mixtures are used. Fither Bordeatux mixtme or limb-sulphum with neutral alsenate of Iead, acoording to Cieo. I'. (iray of the sitate Tniversity of California, may he safely used. or Boreleamx with either the acid of nentral arsenate of leat. Zine arsenite should not be used with either Bordeaux or lime-sulphur.

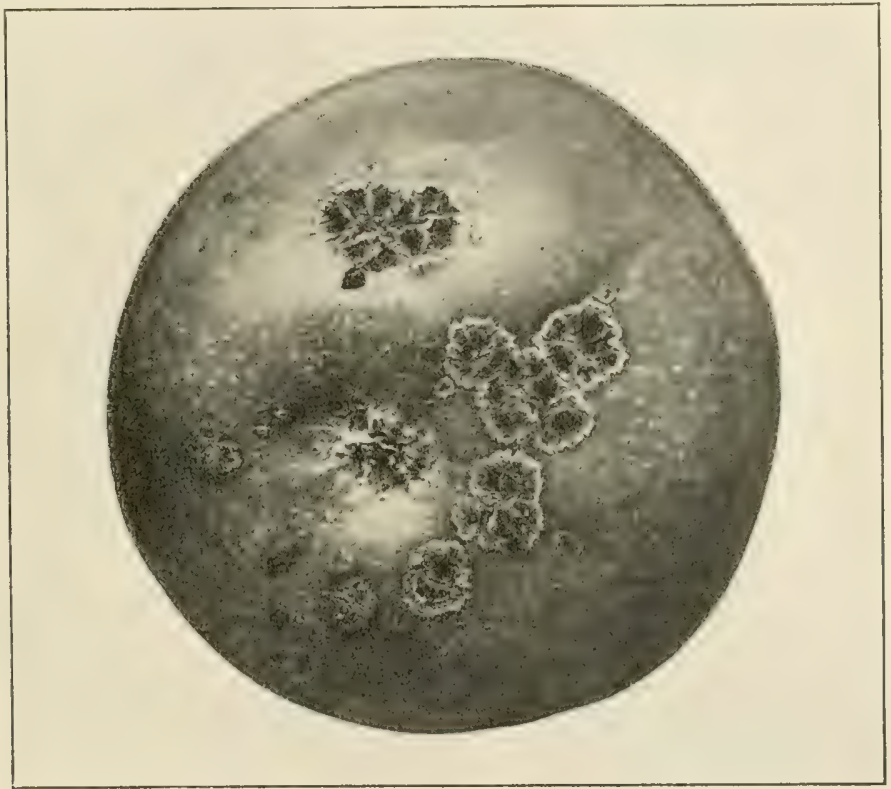

FIG. 49.-Rhode Island Greening affected with apple scab. (Original)

CROWN GALL.

(Bacterium tumefaciens.)

This is a very common disease of the apple, often found on nursery trees, and sometimes becoming so abundant that ereat numbers of them have to be destroved. Trees with this disease, if planted in the orehard. may live for vears, but are usually stunted and never derelop into the best type of trees.

The canse of this affection is known to be a bacterium. which often enters through a wound. thus starting the disease, which manifests itself in swellings or galls. 'These ocemr on the crowns of trees, as well as the roots. at some distance from the crowns, and are very rarely seen above the ground.

There is no cure for crown gall, but preventive measures, such as inspection and destruction of all affected nursery trexs, may keep it out of the orchard. 


\section{POWDERY MILDEW OF THE APPLE.}

(Podosphara leucotricha and $P$. oxycantho.)

The above disease and seab are the two worst fungous troubles of the apple that ocour in California. Nildew attacks the leaves and tender twigs and is recognized by a whitish powdery appearance of the twigs,

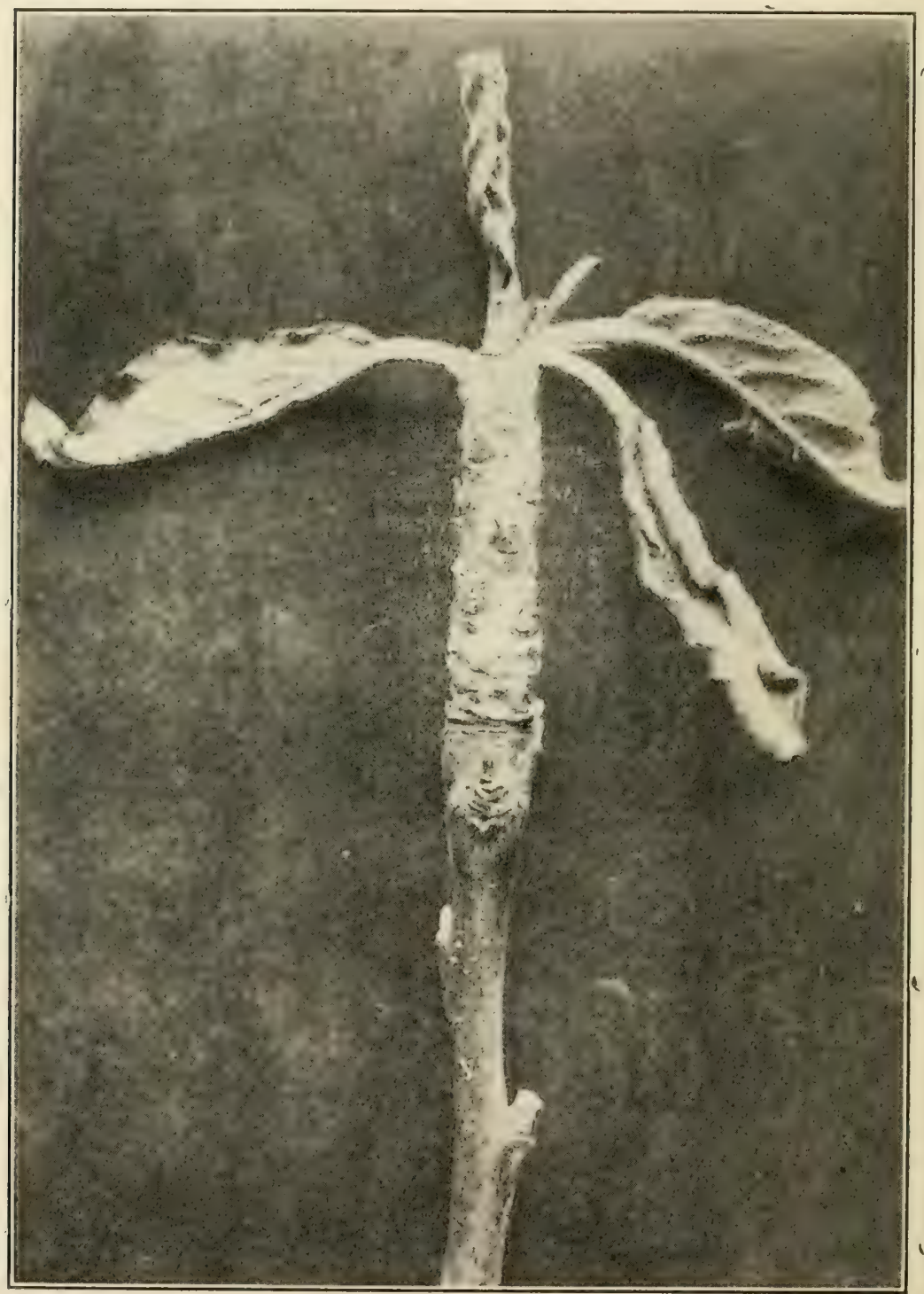

Fig. 50.-Apple twig affected with mildew, showing characteristic appearance. (After R. E. and Elizabeth H. Smith)

both in the summer and winter seasons. There is also more or less curling of the leaves. According to Bulletin No. 120, recently published by W. S. Ballard of the Bureau of Plant Industry and W. H. Volek, 
Comuty Commissioner of Santa ('ruz County, the winter is spent hoth in dormant buds and as spores in black patehes on the twigs. The disease may be started in the spring from the fumgus in the dormant buds or from these black patches on the twies, the former being the common souree of infestation in the Pajaro Valley. The climatice conditions of that section are said to favor very ereatly the derelopment of the disease. At high altitudes, wherever apples are grown, serious infestations have beren found. Ilere again moisture conditions are such as to ageravate the trouble. The authors of the previously mentioned hulletin recommend finely divided sulphur in some form as the rery best mildew fungicide. Ordinary flowers of sulphur is not fine enough for good results. The following instructions and formula are copied from their bulletin and this formula has given general satisfaction wherever it has been tested out:

\section{Preparation of the Iron-Sulphid Mixture.}

The following directions are for the preparation of sufficient stock iron-sulphid mixture to make 500 gallons of spray : Fill a 50 -gallon barrel about two thirds full of water. Weigh out 10 pounds of iron sulphate (copperas), place in a sack, and suspend in the water. The iron sulphate will dissolve fairly rapidly, and when it is all in solution measure out carefully $2 \frac{1}{3}$ gallons of commercial lime-sulphur solution testing $33^{\circ}$ Baumé, or 2 gallous and 3 pints of a lime-sulphur solution testing $32^{\circ}$ Baumé. Slowly pour all but 2 pints of the lime-sulphur solution into the ironsulphate solution in the barrel, stirring the mixture vigorously with a hoe or shovel. The addition of the lime-sulphur solution will produce a bulky, black precipitate, and when all but 2 pints of the lime-sulphur solution has been added the mixture should be allowed to stand for a few minutes, when the black precipitate will begin to settle and a little of the clear liquid at the top can be carefully dipped out with a clean glass or cup. This clear liquid will probably show no yellow lime-sulphur color, which means that an excess of lime-sulphur solution has not yet been added. In other words, there is still some iron sulphate in solution, in which case the addition of a drop of lime-sulphur solution to the clear liquid in the glass will produce a black precipitate. This means that more lime-sulphur solution. should be added to the stock in the barrel, and about half of the remaining 2 pints should now be poured in and the contents of the barrel stirred rigorously and allowed to stand. Some of the clear liquid should again be dipped off and tested as before, to determine whether an excess of lime-sulphur solution has been added. If necessary, the addition of small quantities of lime-sulphur solution should be continued until some of the clear liquid dipped from the top, after the contents of the barrel have been well stirred and allowed to settle, shows a pale yellowish lime-sulphur tint. The purpose of using a slight excess of the lime-sulphur solution is to insure all the iron sulphate being utilized. The voluminous black precipitate that is formed consists of iron sulphid. precipitated sulphur, and calcium sulphate. After a slight excess of lime-sulphur solution has been added, the barrel should be filled with water and the contents stirred thoroughly and allowed to stand for several hours. 'The black iron-sulphid mixture will settle into the lower half or third of the barrel. and the clear liquid should be poured off by carefully and gradually tipping the barrel, without allowing any of the biack precipitate to run out. The barrel should again be filled with water, the contents thoroughly stirred and allowed to stand several hours, and the clear liquid poured off as before. This operation of washing the precipitate should be repeated until the water poured off no longer shows the yellow lime-sulphur tinge. Probably three or more such washings will be required, depending upon how careful the operator has been in using only a slight excess of lime-sulphur solution.

It is evident that the preparation of this stock supply should be commenced two or three days before the spraying is to be done, but when once prepared it may be kept indefinitely. If care is used in weighing out each lot of iron sulphate and if the lime-sulphur solution used is accurately measured there will be no trouble in making 
up the stock supplies rapidly after the first two or three batches have been prepared. and it will be remembered that each batch is sufficient for making 500 gallons of spray mixture. In order to keep a supply of the stock mixture on hand, several batches should be prepared before the spraying commences, and as rapidly as a barrel is emptied the preparation of a new batch should be started. Iron sulphate is comparatively cheap, and the entire cost of materials for preparing 100 gallons of the mildew spray, when diluted according to the recommendations given in this bulletin, should not exceed 15 or 20 cents.

When the washing has been completed, the stock barrel should be filled with water 10 exactly 50 gallons. The material is now ready for use as directed under "General formula for the spray mixture," but care should be taken to stir the contents of the barrel thoroughly each time before any of the mixture is taken out.

\section{General Formula for the Spray Mixture.}

Stock iron-sulphid mixture20 yallons

Arsenicals and nicotine solution to be added as required.

Water, to make. 200 gallons

When arsenicals and a nicotine solution are to be used in conjunction with the iron-sulphid mixture, the combined spray may be prepared by first running about 150 $\mathrm{O}^{\circ} 160$ gallons of water into the spray tank. 'The agitator is then started and the 20 gallons of stock iron-sulphid mixture is poured in, after which the nicotine solution and the arsenicals may be added in the usual way. Sufficient water should then be added to make 200 gallons.

This same strength of iron-sulphid mixture, namely, 20 gallons in 200 gallons of spray, is to be used in all the mildew applications. It will be seen that the 20 gallons of stock mixture used in each 200 gallons of spray contains the product from 4 pounds of iron sulphate.

There are other products besides iron-sulphid which contain sulphur in a very finely divided form that can be used just as effectively in the control of mildew. The California Spray Chemical Company at Watsomville is supplying a form known as "Milled Sulphur," and both the General Chemical Company and Balfour, Guthrie \& Co., of San Francisco, sell another product inder the trade name of "Atomic Sulphur." No doubt there are still other forms that could be used to good advantage, the essential qualifications being the fincly divided state of the sulphur, as has already been indicated.

As is true with most diseases of this nature, a thrifty strong growing tree is apt to resist attacks to a greater or less extent. Consequently, it is very desirahle that everything be done towad keeping orchards in the hest possible condition. Thus fertilization mar be a great benefit. and Ballard and Volck recommend spraying during the early spring with a crude oil "mulsion, which has a tendency to stimulate growth. Pruming is an important means of checking this disease. All infested twigs which are noticed during the time of pruning, either in the dormant or summer season, should be cut from the trees. 


\section{PICKING, GRADING AND PACKING.}

PICKING.

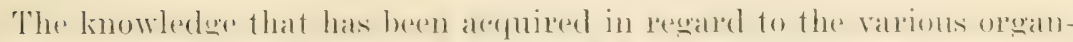
isms which produre dexa! in fruts, and that many wain antrance only where the skin is broken by bruising or where a worm lias entered, has resulted in much ereater care heing taken, when picking apples, than formerly. How well catn we all remember the time when the apples high in) in the trees were shaken to the eround or knocked down with a pole rearadless of the injury done to them in falling. It is now known that only the somed apples will keep well when parked. and even slight bruises will act as starting points for dexay and the ruination of the

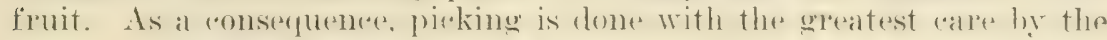

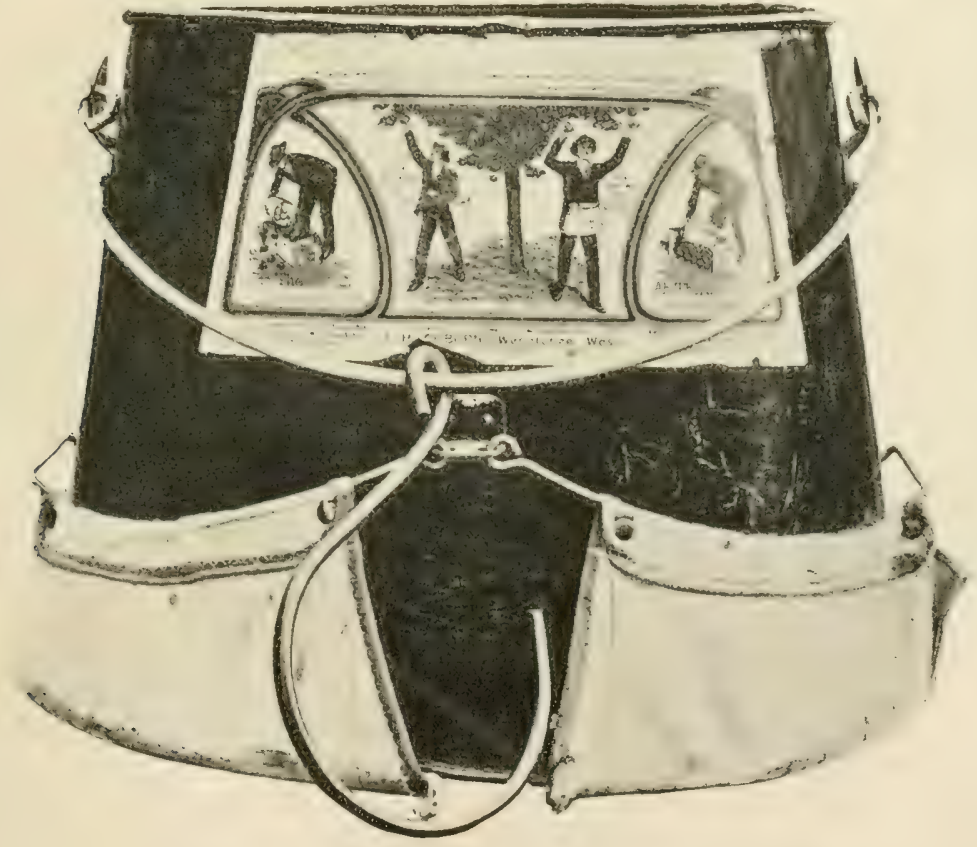

Fig. 51.-A good type of picking bucket. (OriginaI)

hetter orehardists and the handling of the fruit is done as carefully as though one were handling eggs. As far as possible all stems should remain intact after fruit is picked.

When pulled from the trees the apples shomld be carefully placed in the pieking hag. ('areless dropping of the fruit into the hase may result in many bruises, and again when emptring from the hag into at box, care should be exereised so that they are not allowed to drop too far. The type of picking bucket shown in Fig. 51 has a canvas hottom which opens when heing unhooked at the side. and the apples are emptiod 
inte the box without danger of bruising, provider that the picking vessel is not held tno high when opened. There are a number of good picking bags made somewhat like the one shown in the picture, any of which will give good service, providing that they are used by eareful pickers. Common buckets of small size are sometimes used and are quite satisfactory, but are not so conveniently emptied as vessels with the collapsible bottoms.

\section{GRADING.}

The grading of apples is usually done in the packing-houses. Fig. 52 shows boxes of apples in house awaiting this work, which is sometimes

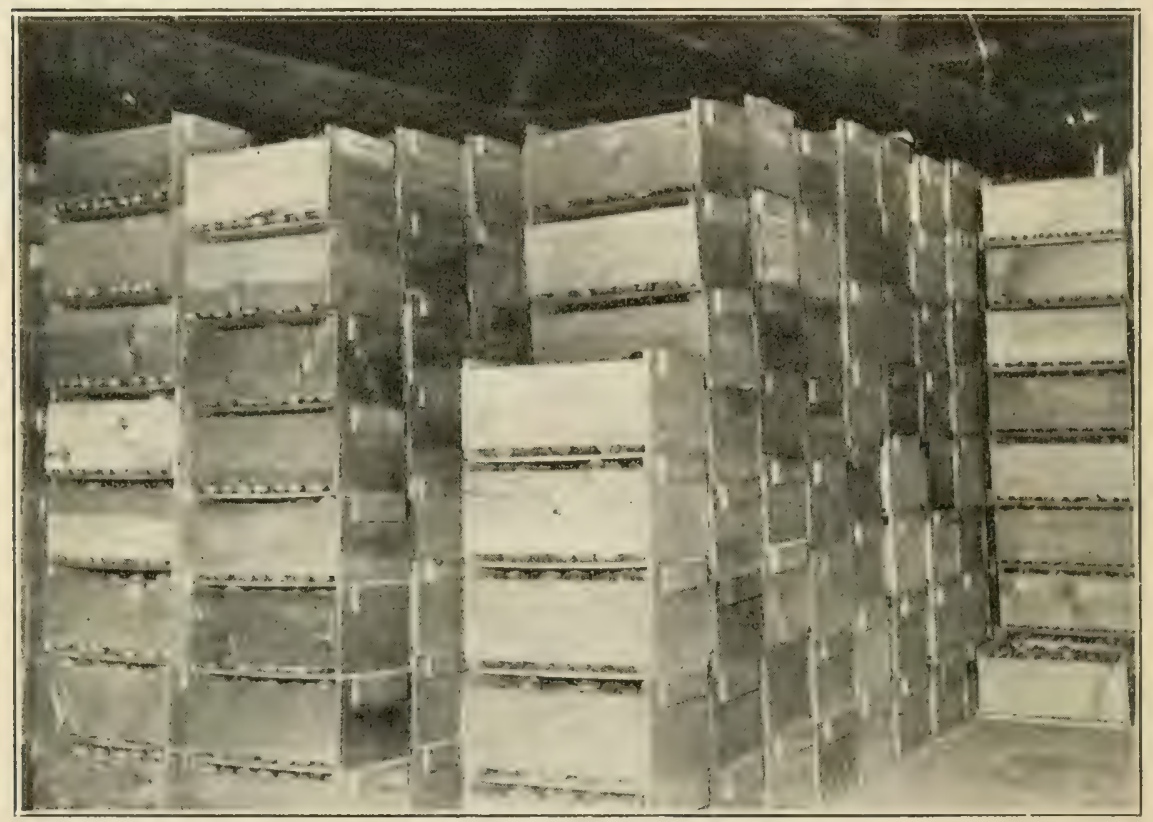

Fig. 52,-Boxes of fruit in the packing-house ready for grading. (Photo by C. B. Weeks)

done by means of mechanical graders, of which there are a number of different types on the market. Some of these are said to be very satisfactory, while others are apt to bruise the fruit more or less, thus bringing about decay prematurely. Ordinarily such work is done by hand. The beginner is given a board in which holes of different sizes, representing the diameters of the apples that are used in the different styles of pack, are made. These are used simply to train the eye to the various sizes, and are not necessary after one has been doing the work for a short time. All cull apples are removed during the process of grading; that is, such as are stemless, contain worms, worm holes, bruises, limb scars, etc. When mechanical graders are used, all blemished fruit must be pieked out by hand, either before or after it has been put through the grader. 


\section{PACKING.}

IThat we might term the evolution of the apple park has heen very marked in the past quarter century. We can all remember the time when no attempt. was made at grading. small apples and big apples beine put inte the same parekage, usually the formere on the bottom: indered. somere times 110 attempt was made to keep varieties separate and several kinds were plated in the sack, box or barrel and sold together. The West. with its cooperative marketing organizations, has mondoubtedly dome more toward developing a uniform pack and establishing a fancy trade than the rest of the Lnited States. The East, until very recent years. has insisted on putting apples in barrels and. while standardization of the barrel pack could be aceomplished as well as of the box pack, the East has been slower in evolving along these lines, and has of reeent rears been copving after the West, until now apples are often packed in boxes and marketing agencies with their standardized paris are competing with our western organizations.

The boxes that are being used at the present time are variable in size. ('alifornia uses a box that is 9? by 11 by o.) inches: Oregon and colorado have boxes of the following dimensions, respectively: $10 ! b y$

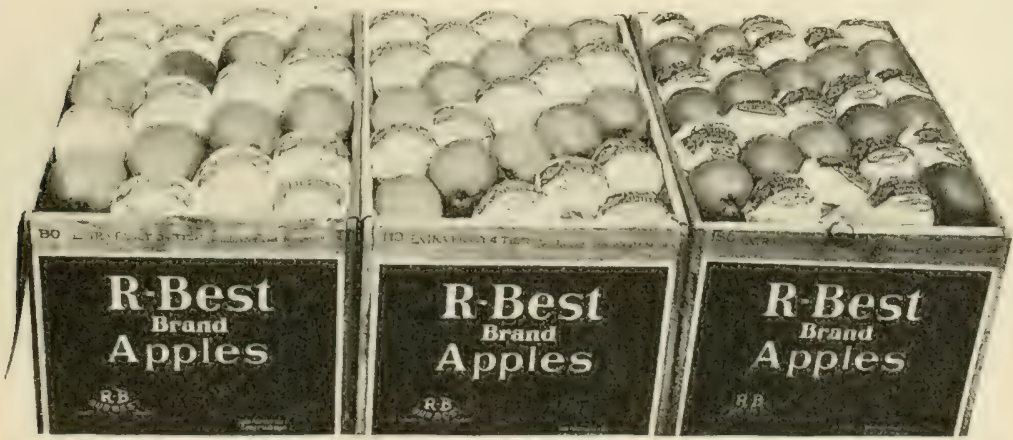

Fig. 5:- Fellow Bellfowers, illustrating $3 \frac{1}{2}, 4$ and $4 \frac{1}{2}$ tier packs. (Original)

$11 \frac{1}{2}$ by 18 inches and 11.12 by 11.12 by 18 inches. A bill, designed to create a standard size and pack, was introduced into the session ef Congress just elosed by Judge J. S. Raker, but failed to pass. With California using one sized box principally, Oregon another and ('olorado still another, it is found to be a difficult matter to agree on a standard, but as standardization in the matter of packages for all fruits is becoming necessary for uniformly good sales, the time will come, no doubt, when the West will agree on a certain sized box to be used and marked as standard.

In the Watsonville section of California, where a splendid pack on the whole is made, there are three packs lnown as :3!, 4 and $4: 1$ tier, with the $t$ tier as the standard, or average size. which is most desirable to the trade in general. This size varies from 25 inches as a minimum to 3 ! inches as a maximmm. The 3.1 tier size contains apples over $3{ }_{1}^{1}$ inches in diameter, and the 11 smaller apples than 2.5. 'These rules are for their' standard varieties: Yellow Newtown and Yellow Bellflower.

In the case of the $3 . !$ and 4 tier apples, the fruit is always mapped by the packers. This practice is one of tremendous value and should be 
followed by every section where apples are produced commercially. such wapping not only facilitates the work of packing. but phahles one to put up a much firmer pack and one less subject to bruising in hoxing and during transportation than could otherwise be possible. The keeping qualities of the fruit are no doubt enhanced to a marked dexpee. Tasteful designs or trade marks may be placed on these wrappers as well as the name of grower and locality, thus adding greatly to the attractiveness of the pack.

Fig. 3:3 shows three hoxes of excedlent lellow Bellflowers grown and packed hy Rodger's Bros. of Watsonville. This picture illustrates nicely the diagonal pack and shows the three sizes, viz: $3 \frac{1}{2}, 4$ and $4 \frac{1}{2}$ tier.

The pack, when made, should be so firm that each apple is held fast by another, and none have any room for play. When covered and

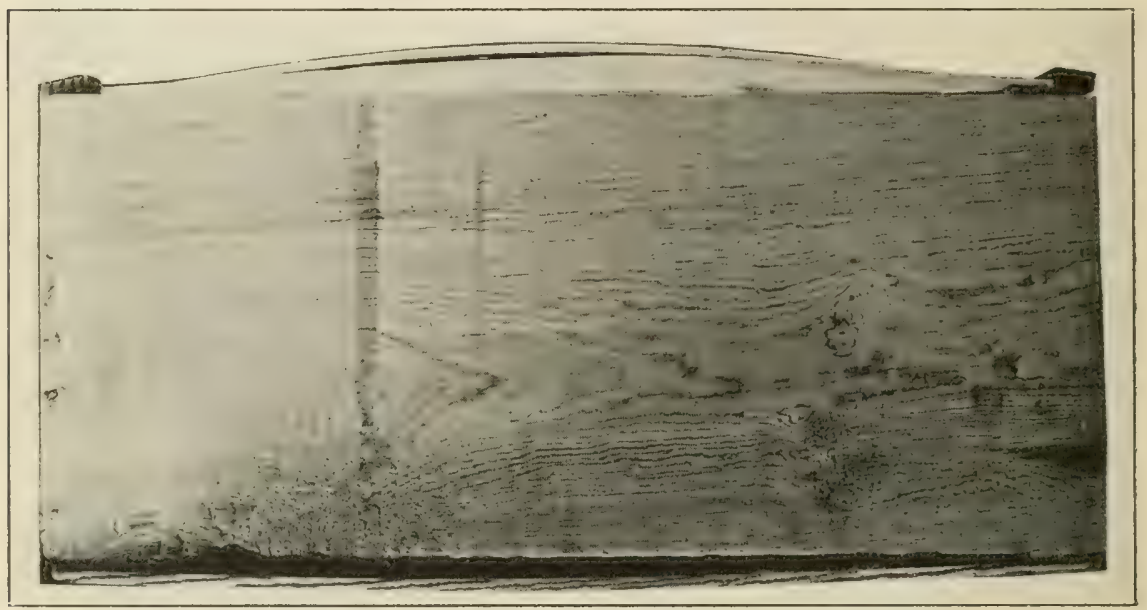

Fig. 54.-A rell packed box of apples with a top bulge of 3 inch. (Original)

mailed there should be a bulge of at least : inch on the top and a slightly lesser amount on the bottom. (See Fig. 54.)

Tasty lithographed labels of various designs are used on the ends of boxes, and such should result in the best kind of advertising for the grower. When the trade learns a label and knows that the man who uses it always exereises the greatest eare in packing his fruit, it may be the means of securing for him a good market. On the other hand. such labels may have the opposite tendency and work injury to the man who persists in packing undesirable fruit and misrepresenting it by the label.

\section{Special Packages.}

While practically all of the fancy ('alifornia apples are wrapped and packed in two sized boxes. viz: the california box and the Oregon hox. there is a certain limited demand. at least. for a smaller package. suth 
as a person could easily carry away from a grocery store. Recognizing this demand. Mr. J. F. Bentom of Areata has been parking apples in artons whieh hold just one third of a hox. Figs. his and 56 show ome of his special cartons packed and ready to seal, and the other sealed. It is probable that large growers close to market would not be justified

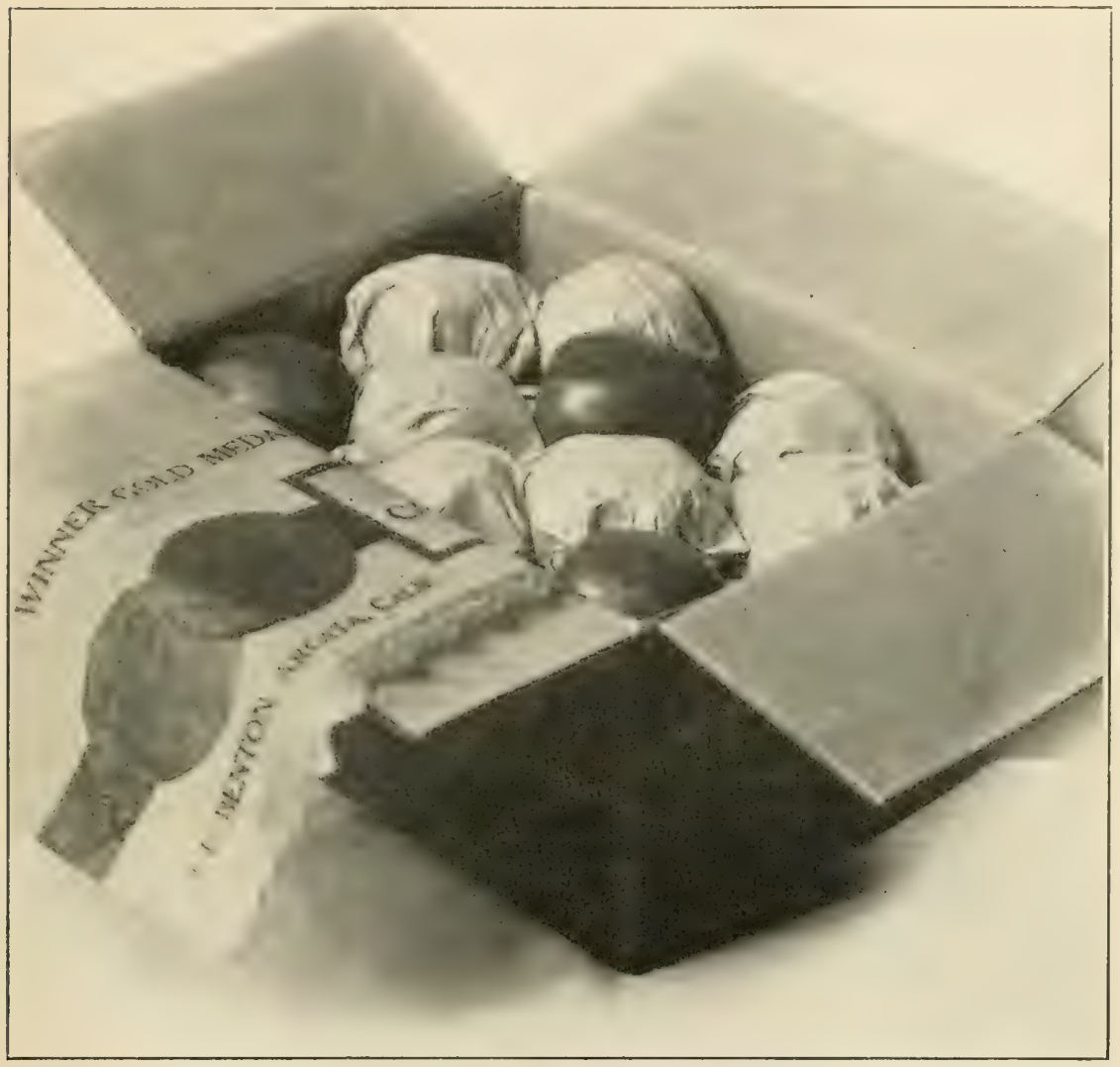

Fig. 55.-Carton used by J. F. Benton of Arcata, which holds one third of a box of apples.

in making such a pack, but on the other hand the grower with a smail orehard, located at a distance from market. might be able to secure a linited faney trade hy packing only the very finest apples in such parkages as these. Mr. Benton secoures his own market and deserves; success in his new venture. 
CHAPTER XVII.

\section{BY-PRODUCTS.}

No matter how carefully an orchard may be sprayed and cared for in general, there is always a considerable loss of fruit because of windfalls, undersized apples, limb bruises, sumburn, ete. Such fruit is not fit to parck and while sometimes the temptation is very strong to put it in boxes and market it, yet the prices received are seldom such as to justify

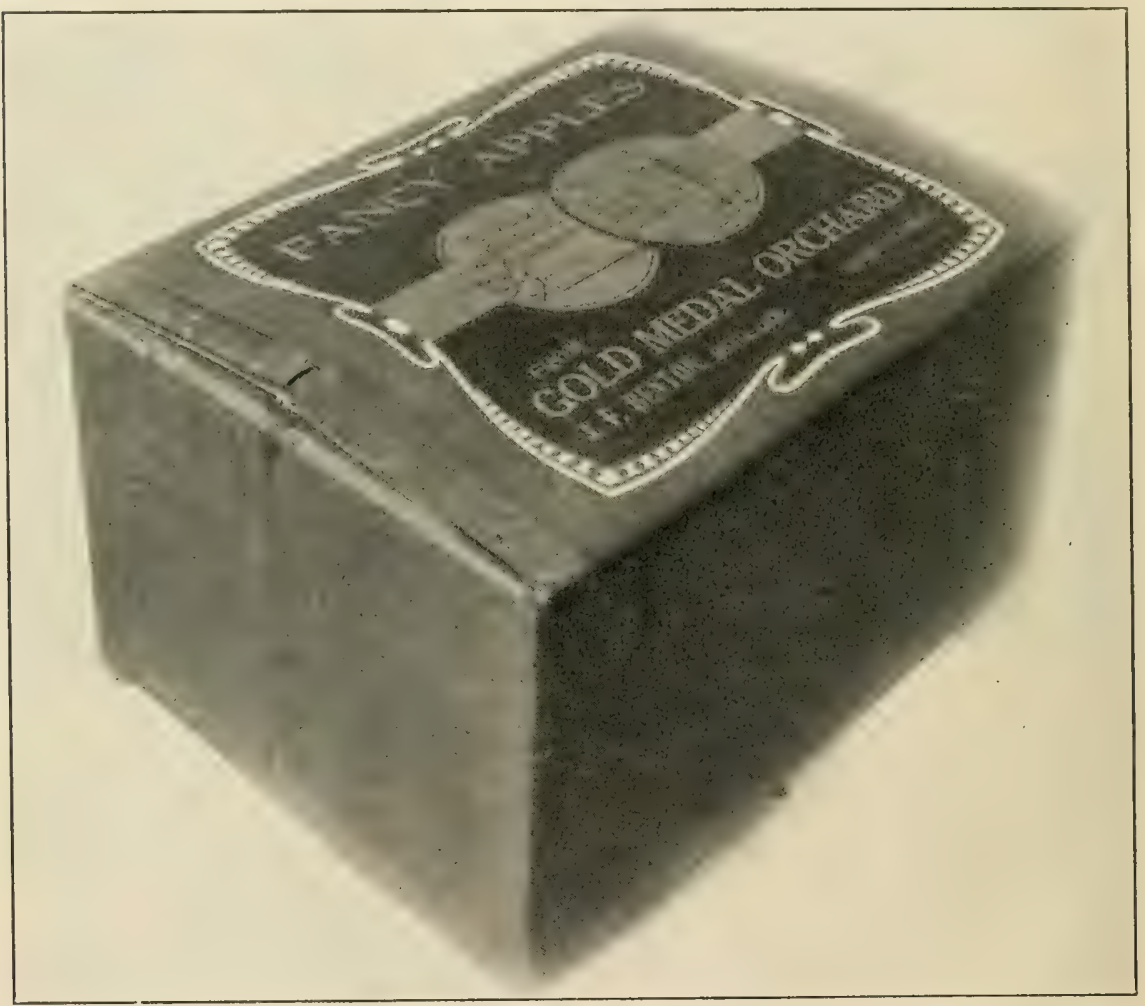

Fig. 56.-The same carton as shown in Fig. 55, after it has been sealed.

the practice. The utilization of all such fruit which, if boxed. brings nothing, and if left in the orchard ordinarily goes to waste, is one of our important problems.

There are many by-products of the apple for which great demand could be created. Some of these are jelly, cider, vinegar, apple butter. dried apples, ete. The drying business has reached quite extensive proportions in the Pajaro Valley.

As an assistant judge at the California Apple Show held at Watsonville in 1913. the writer had the pleasure of helping with the awarding of the first premium for feature exhibits to Mrs. Hugh 
MeGowan, who had ('onstructed with jelly glasses, all full of pure apple jelly of different shades of coloring, a building which was an exart peproduction of the great Watsonville anditorium where the show was held. The dimensions of this anditorimm made of jelly were as follows: length, 15: feet; width, 10 feet; height, about 4 feet.

This season such a buileling was construeted at the California Ipple show held in san Franciseo and was again recognized by the juderes by being awarded third premium for feature exhibits. Fig. 57 shows this excellent rahibit. Mrs. Mceowan certainly deserves much coedit and the thanks of the commmnity in which she lives for her energy in making such a tremendous quantity of jelly and in putting up such an exhibit as the one mentioned. It is hard to foresere what the development of this one industry may mean to the Watsonville section. This is just an illustratim of the great possibilities that there aro for those who will take advantage of them.

Recently while visiting some of the fruit orehatreds in the Julian section of San Diego County-which is not easily accessible-the writer was

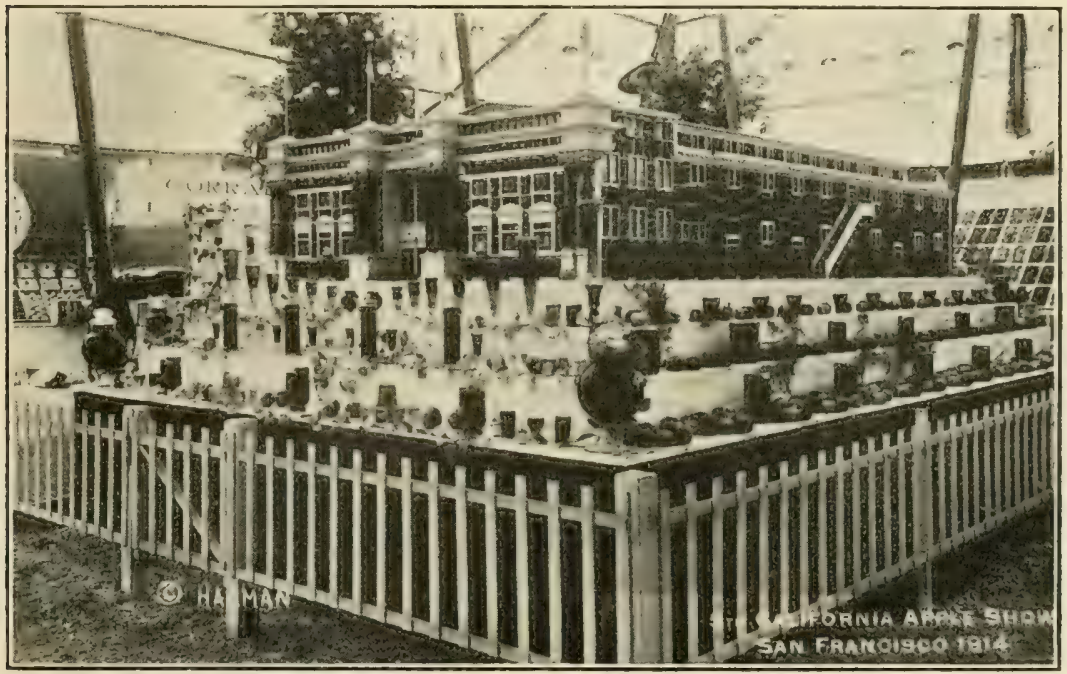

Fig. 57.-Model of the Watsonville Auditorium made from glasses filled with pure apple jelly. Exhibited by Mrs. Hugh McGowan at the Annual Apple Slow in San Francisco.

pleased to find an up to date plant, on the ranch belonging to S. A. Walters, for the manufacture of apple butter, cider, vinegar amel other by-products. Mr. Walters has undoubtedly solved the prohlem of getting good returns for his fruit. While it might be easy to orerdo the manufacture of some of these by-products, yet it would seem that there are great possihilities, particularly for orchardists who are a long way from market and who have no provision for storing their fruit. As has alrearly been mentioned. one of the chief reasons for manufacturing by-products is that there is ordinarily a great waste of imperfect fruit. The aim should always be to grow the best possible apples which may be packed and sold, most seasons, to good advantage. There will, however, come seasons of low prices when even the very best can be ntilized in the manufacture of such by-products as seem best. and in this way a good market will be insured. 


\section{PRODUCTION, CONSUMPTION AND RECIPES.}

Statisties show that the areager of apples has been greatly increased

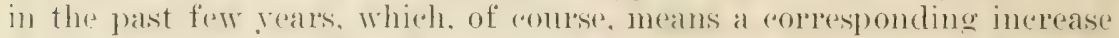
in the production. The East is also awakening to the possibilities in apple growing, and where thousands of acres of this frut were destroyed hy San ofosé suale not many years ago, new orchards are heing set out and the West must be prepared to meet this competition.

It has already been stated that the apple crop varies in size from season to seasom, largely on account of killing speing frosts in different parts of the country. This variation in size means a fluctuation in prices. which range from very high in one season to very low in another. l)uring seasons of light apops the marketing problem solves itself, but during seasons of rery heavy crops there is always damerer of prices being so low as to make apple growing umprofitable. It is this fact that should make us bend every effort toward increasing the consumption of apples, in order to lessen the possibility of overproduction and conserpuent low prices for our fruit.

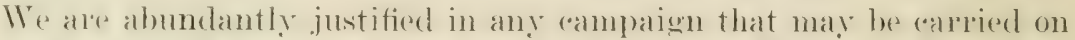
with the aim of increasing eonsmmption. becanse of the excellent food value of the apple. Much has been done in the past ferl years to educate the people alone this line. The splendid apple shows that have been held in different parts of the country have taken a leadine part in this work. In our own state the great California apple show-which is mslally held ammully at Watsonville, but this year at San Franciseoand the anmual Sebastopol Grarenstein show, have adrertised in an 'mphatice way the value of the apple as food. Who eould look at a tasty jelly exhibit, such as Mrs. Mc. Gowan's, shown in Fig. 57, without having a better taste created for apple jelly? Or who could look at the splendid "xhibits of Gravensteins at the Sebastopol show (Fig. 58) without going away feesling that he must huy a box of firavensteins when he gets home?

()ur frut jommals have also done much toward increasine the ronsumption of this, the best of all fruits. In 1912 the October number of "Better Fruit," published at Ilood River, Oregon. printed a list of zog ways for cooking the apple. These recopes were gathered hy I. Gertimcle Mackay, of the domestic seience department. Pullman, Washington. With the help of MIs. Weldon 50 of these have heen selected and are here printed, in hopes that they may reach many housewives of California, who will be encouraged to try them and cook more apples than they otherwise would, thus aiding in the work of increasing the consumption. 


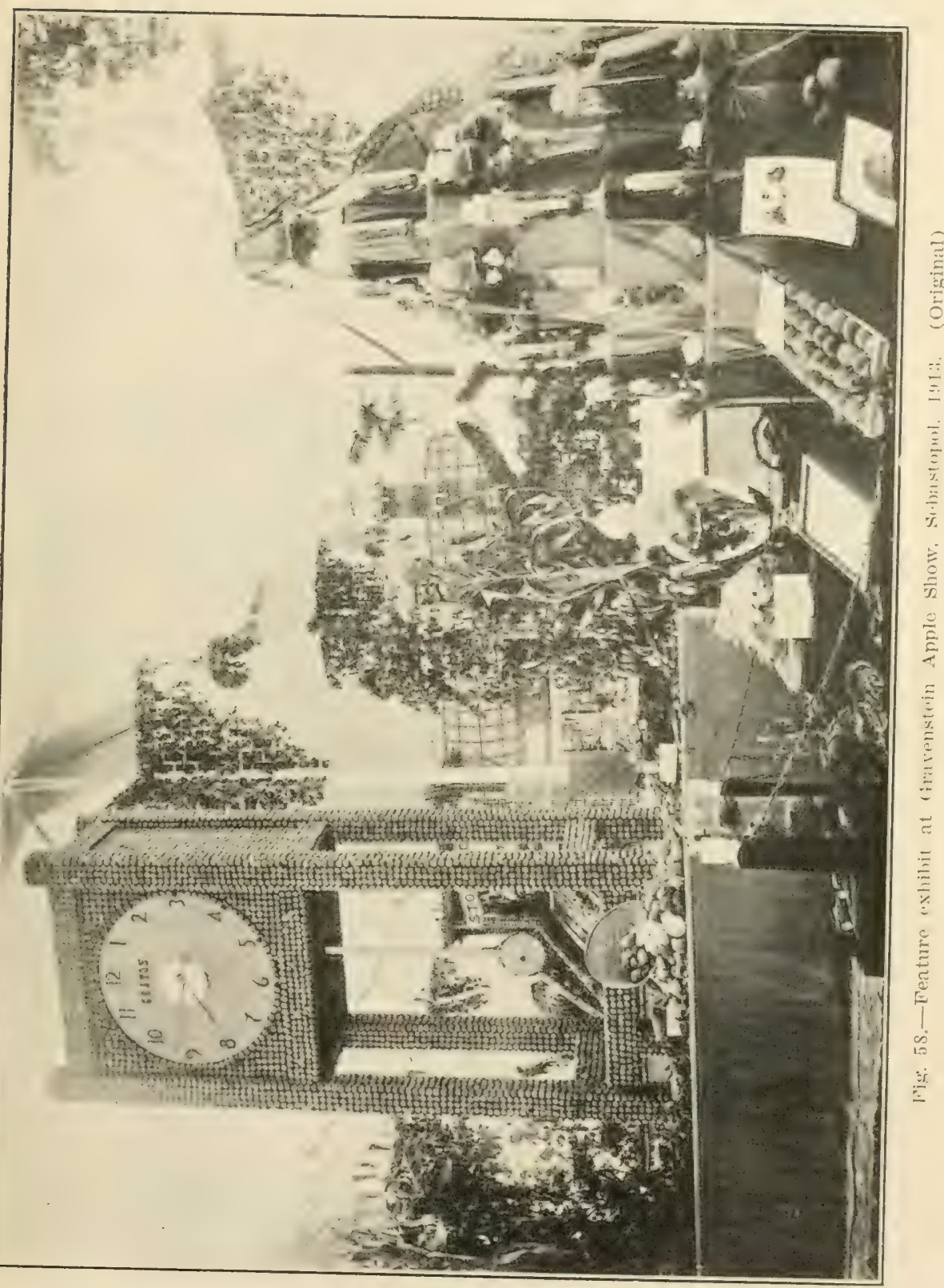




\section{RECIPES.}

1. Buked Apples.-Peel and core tart apples; fill the holes with shredded citron. vaisins, sugar and a little lemon peel. Place in baking dish and pour over them one half cup of water and dust with granulated sugar. Bake in a slow oven until perfectly tender and sprinkle with soft bread crumbs and sugar; bake for ten minutes. and serve hot with cream or pudding sauce.

2. Apple Fritters, English Stylc.-Beat one egg, add a few grains of salt and one. fourth cup of milk; cut out four rounds of bread from half inch slices of stale bread; set the bread into the milk and egg mixture and cook in deep fat.

Stew apples, pared and cored, in a few spoonfuls of syrup. Place an apple on each round of bread and grate a little nutmeg over the top. Serve very hot.

3. Afterthought.-One pint of nice apple sance sweetened to taste; stir in the yolks of two eggs well beaten. Bake for fifteen minutes. Corer with a meringue made of two well beaten whites and one half cup of powdered sugar. lieturn to the oven and brown.

4. Apricot Sherbet Served in Apple Shells.--Select bright red apples of uniform. size, rub until they have a high polish. Cut off the blossom end and scoop ont the pulp; carefully notch the edge. Fill with apricot sherbet and serve upou apple leaves.

5. Apple Balls with a Mixture of Fruit.-Peel large apples, with a potato scoop. cut out small balls, dropping them into water with a little vinegar added to keep them white. Prepare a mixture of grapefruit pulp, pineapple and banana and put into glasses; add a few of the apple balls, pour over all the juice left from the fruit which has been loiled down with sugar; cool and serve at once or the apples may turn brown.

6. Apple Balls Scrved in Syrup.-Prepare the apple balls as above; prepare a rich sugar syrup; color with a little pink color paste and drop in the balls, cook slowly until the balls are softened, pile in glasses and add a little syrup to each glass. Serve cold.

7. Brown Betty.-Pare and chop six apples; place a layer of apple in a well buttered pudding dish, then a layer of bread crumbs, sprinkle with brown sugar and cinnamon, repeat until the dish is full; add several generous lumps of butter and peur sweet milk or hot water on until it comes within an inch of the top of the pan. Bake in a moderate oven until brown and serve with plain or whipped cream.

S. Apple Butter.--Pare, core and quarter the desired quantity of apples, allowing one third of sweet to two thirds of sour apples. Boil sweet cider until it is reduced one half. While the cider is hoiling rapidly add apples until the mixture is the desired thickness. Cook slowly, stirring constantly and skimming when necessary. When the apples begin to separate from the cider take two pounds of sugar to each bushel of apples used; add a little ground cinnamon and boil until it remains in a smooth mass, when a little is cooled. Usually one and one half bushels of apples are enough for one and one half grallons of boiled cider.

9. Apple Biscuit.-To one pint of light bread sponge add one quarter cup of molasses, one teaspoonful of lard and graham or whole wheat flour for a soft dough. Reat vigorously and finally work into the dough one large cup of chopped apple: shape the dough into biscuit aud piace in muffin pans and allow them to be very light before baking.

10. Dried Apple Buttcr.-Wash one pound of dried or evaporated apples thoroughly, soak over night; in the morning cook with plenty of water. When well donerub through a sieve or colander; add sugar and cinnamon to taste, the juice of one lemon, juice of two oranges and butter the size of an egg. Cook slowly until it will drop heavily from a spoon. 
11. Apples En Casscrole-Pare, core and slice two quarts of apples and put in an earthen dish, alternately, with one and one half cups of sugar; add one fourth cup of cold water, cover the dish and bake in a moderate oven. Serve either hot or cold with cream.

12. Apple Charlottc, I.-Soak one half a box of granulated gelatine in one half cup of cold water for half an hour. Whip one pint of cream and set on ice; add one half cup of powdered sugar, a tablespoonful of lemon juice and two good sized apples, grated. Dissolve the gelatine orer hot water and strain into the mixture; stir quickly and pour into a mould. Set on ice to chill and serve.

13. Apple Charlotte. II.-Pare, core and slice apples; cook in butter until soft and dry; add sugar to taste. Line a plain mould with sippets of bread an inch wide, dipped in melter butter : let one overlay the other; artange lozenges of bread similarly in the bottom of the mould. Fill the center with the apple and cover the top with bread. Bake for half an hour in a hot oven. Serve with cream and sugar or a hot since.

14. Plain Apple Charlotte.-Soak one quarter of a box of granulated gelatine in two tablespoonfuls of cold water; add to one pint of hot apple sauce, flavor and press through a sieve. As soon as the mixture begins to harden stir in one pint of whipped cream. Line a mould with ladyfingers, pour in the mixture and set away to cool.

15. Apple Cobbler.-Pare and quarter enough tart apples to fill a baking dish three fourths full. Cover with a rich baking powder biscuit dough made soft enough to stir, spread it over the apples without rolling. Make several cuts in the center to allow the stean to escrue. Bake for three quarters of an hour and serve hot with sugar and rich cream.

16. Coddled Apples. - Take tart, ripe apples of uniform size; remove the cores. Place the fruit in the bottom of a porcelain kettle, spread thickly with sugar; cover the bottom of the kettle with water and allow the apples to simmer until tender. I'our the syrup orer the apples and serve cold.

17. Apple Conserve.-For each pound of quartered and pared apples allow three quarters of a pound of sugar and half a pint of water. Boil sugar and water until a rich syrup is formed; add the apples and simmer until clear. Take up carefully, lay on plates and dry in the sun. Roll in sugar and pack in tin boxes lined with waxed paper.

18. Compote of Apples.-One pound of apples, one quarter pound of lump sugar, one cup of water, the juice of half a lemon, a few drops of red coloring. Put the sugar, water and lemon juice into a clean enameled sauce pan and let them boil quickly for ten minutes. Meanwhile peel the apples, cut them in quarters and remove the cores. Throw the pieces into the boiling syrup and let them cook slowly until clear and tender, but not broken. 'I'hen remove the quarters of apples carefully, reduce the syrup a little and color it pink with the red coloring. Arrange the apples on a glass dish and pour the syrup over. A little cream or custard served with the compote is a great improvement. If the apples are small they may be cored aud cooked whole.

19. Apple Compote and Orange Marmalade-Boil twelve tart apples in one quart of water until tender. strain through a jelly bag: add one pound of granulated sugar and let boil. While boiling add twelve apples, cored and pared. When the apples are tender drain them carefully in a perforated skimmer. Boil the syrup until it jells; fill the apples with orange marmalade and pour the syrup over them. Serve with whipped cream. 
20. Crab imple Marmalade. - Wash and core crab apples and put them through the meat chopper. Put into a preserving kettle aud add water until it shows through the top layer of apples. Cook until soft. Weigh and add an equal weight of sugar. Cook until the mixture forms a jelly when cooled and pour into sterilized glasses. Cover with paraffine.

21. Apple Custurd.--I Beat the yolks of foul eggs and add one half cup of sugar : cook for one or two minutes and remove from the fire. Gradually add one pint of grated apple. Pour into a serving dish and cover with a meringue made of the well beaten whites of four eggs and three tablespoonfuls of powdered sugar.

22. Apple Cup Custard.-Pare, core and steam four cood sized tart apples until tender; press through a sieve. While hot add one tablespoonful of butter, four tablespoonfuls of sugar, the yolks of four eggs and one half pint of milk. Turn into baking cups and bake for twenty minutes. Beat the whites of four eggs until stiff, add four tablespoonfuls of sugar, beat and heap over the top of the cups; dust thickly with powdered sugar and brown in the oven. Serve cold.

23. Apple Custarls. - Steam two large tart apples that have been peeled and cored. Rub them through a sieve and add one cupful of milk, two teaspoonfuls of butter, one quarter of a cupful of sugar and the yolks of four eggs. 'Turn the mixture into baking cups, stand them in hot water and bake about twenty minutes. When they come from the oren pile the beaten white of egg on top of each cup, sprinkle with powdered sugar and place in the oven to brown slightly. Serve cold.

24. Apple Croquetcs.-I'are, quarter and core enough tart apples to make a pint; place in a saucepan with one small tablespoonful of butter and, if the apples are not juicy, a few tablespoonfuls of water. Cover and stew gently until tender, then press through a sieve. Return to the fire and add sugar. Add one tablespoonful of cornstarch and one quarter of a teaspoonful of salt, mix to a thin paste with cold water; stir until thickened, cover and cook slowly for fifteen minutes. Turn out on a greased dish and set away until cold. Form into tiny croquettes, roll in bread crumbs, dip in lightly beaten egg, then roll again in crumbs and fry in deep fat; drain on unglazed paper and serve with roast pork or roast goose.

25. Delmonico Lpples.-Put a layer of apple sance in a buttered pudding dish, sprinkle with ground almonds, dot with butter and sprinkle with crushed macaroons, add a little water and bake. Delicious when served with meat.

26. Apple Delight.-Put a layer of apple sauce in a buttered pudding dish, dot with butter, add a layer of chopped peaches and apricots, sprinkle with blanched almonds, ground rather coarsely; repeat until pan is full; pour the peach juice over the mixture and bake for one hour. Serve as a relish with meat course.

27. East India Chutney (Apple).-Pare and core twelve sour apples. Peel one medium sized onion. Remove seeds and stems from three peppers, one of which should be red. Chop apples, peppers, onion and one cup of raisins very fine; add the juice of four lemons, one pint of cider vinegar and half a cup of currant jelly: let simmer very gently for one hour, stirring frequently. Add one pint of eider vinegar, two cups of sugar, one tablespoonful each of salt and ground ginger and one fourth of a teaspoonful of cayenne; cook for one hour more, stirring constantly. Store as canned fruit.

2S. Apple Farci.-Choose tart red apples, Northern Spys if possible; wash, wipe and core. Do not pare. With the corer remove apple in three places, equally distant from stem and blossom end, holding corer in oblique position and pressing downwarl toward center. Fill these cavities with raisins, dates or figs, sugar, cinnamon. Canned or fresh pineapple is delicious filling. Always use raisins, placing them in the eavities first to prevent the other filling from slipping through. After filling place the apples in a pan that has been sprinkled with sugar and cinnamon. Sprinkle 
each apple with sugar and cinnamon. I'lace in a hot oven until the sugar melts. then add one fourth enp of water or fruit juice and bake until tender. Baste frequently with the syrup. Serve either hot or cold with whipped cream sprinkled with cocoa.

29. Apples Fried with Onions.-Peel onions and slice. ly' in fat until a rich brown; drain on soft brown paper. Fry umpared quarters of apple in the fat left from the onions. Arrange apples in a border on a platter. fill center with the fried onions and serve them hot.

30. Fricd $A p p l e s$-Q Quarter and core five apples without paring. l'ut into a frying pan and melt beef drippings: when hot lay a layer of apples in it, skin side down, sprinkle with brown sugar, and when nearly done turn and brown; place on a platter and sprinkle with sugar; set in hot oven and continue frying apples one layer at a time.

31. Apule Fritters, I.-Mix and sift one and one third cups of flour, two teaspoonfuls of baking powder and one fourth teaspoonful of salt. Add gradually, while stirring constantly. two thirds of a cup of milk and one egg well beaten. Wipe, core, yare and cut two medium sized sour apples into eighths, then slice the eighths and stir into the batter. Drop by the spoonful into hot deep fat and fry mutil delicately browned; drain on brown paper and sprinkle with powdered susar.

32. Apple Frittcrs, II.-Pare and core four tart apples and cut in one fourth inch slices across the apple. Sprinkle with two tablespoonfuls of lemon juice and powdered sugar. I'repare a batter by sifting one cup of flour and one fourth teaspoonful of salt. Idd two well beaten yolks to one half cup of milk: mix and beat into the flour until smooth. Add one tablespoonful of melted butter or olive oil and cut in the well beaten whites of two eggs. Drain the apples, dip into the batter and fry in deep fat. When cooked drain on brown paper and sprinkle with powdered sugar before serving.

33. Oxford Apples.-Pare, core and quarter four large tart apples and boil in very little water. Mash and add one tablespoonful of butter, half a cup of sugar, half a cup of fine bread crumbs, the yolks of four eggs and the whites of two eggs beaten light. Pour into a baking dish and cover with a meringue made of the whites of two eggs and two tablespoonfuls of powdered sugar and brown.

34. Apples with Oatmenl.-Core apples, learing Iarge cavities, pare and cook in a syrup made by boiling one cup of sugar with one and one lalf cups of water for five minutes. When the apples are soft drain and fill carities with the hot. well cooked meal and serve with cream and sugar.

35. Sausagcs and fricd Amples.-Prick the sansages well with a fork. I'lace in a (ieep frying pan, pour in enough boiling water to cover the bottom, cover and cook over a moderate fire. When the water exaporates remove the cover and turn several times that they may be nicely browned. 'Turn on to a platter. Core a number of large tart apples, cut them in rings an inch thick and fry in the sausage fat. Garnish the sausage with the apples and serve.

36. Apple Tapioca. - Soak three fourths of a cup of tapioca in water for one hour to cover, drain, add two and one half cups of boiling water and one half teaspoonful of salt; cook in double boiler until transparent. Core and pare apples, arrange in a buttered baking dish. fill cavities with sugar, pour tapioca over apples aud bake in a moderate oven until the apples are soft. Serve with sugar and cream or with cream sauce. Sago may be used instead of tapioca.

Crean Sauce. Mix and beat until stiff three fourths of a cup of thick cream and one fourth of a (up) of milk, ald one third of a cup of powdered sugar and one half teaspoonful of vanilla. 
37. Apple Water-Wipe, core and pare one large sour apple, put two teaspoonfuls of sugar in the cavity; bake until tender, mash, pour one cup of boiling water over it and let stand one half hour and strain. This is especially refreshing for fever patients.

38. Apple Christmas Pudding.-Pare, core and quarter six tart apples. Add a cup of water, cover ant boil quickly for five minutes. Press through a sieve; add a tableslroonful of butter and a cup of sugar. Beat three eggs until light; add one pint of milk and a cup of hot boiled rice. Add the apples and bake for half an hour. Lcmon and orange rind may be added. Serve cold with cream or lemon sauce.

39. Apple Sauce Pudding.-Cream one quarter cup of butter with one half cup of brown sugar: add one beaien egg. two tablespoonfuls of milk, one half teaspoonful of baking powder and enough flour to make a stiff batter. Bake in two layers, put together while hot with apple sauce and serve with custard.

40. Apples Baked in Stravoberry Jam.-Core tart apples aud place in a baking dish; fill the cavities with strawberry jam and bake until soft. Serve hot with cream.

41. English Apple Pie.-Butter a shallow agate dish. Select one that is deeper than a pie plate. Fill the dish with sliced apples, sprinkle with a cup of sugar, half a teaspoonful of salt and a little nutmeg. Put over it two teaspoonfuls of butter in bits; add three tablespoonfuls of cold water. Cover with good paste and bake for forty minutes. Serve with cream.

42. Pot Apple Pic.-Peel and quarter eight nice tart apples (Greenings are the best), and slice in strips about half a pound of fat salt pork and mix a nice light biscuit dough. Then take an iron kettle and lay strips of the pork across the bottom about half an inch apart, then lay on that loosely some of the quartered apples, then sugar and cinnamon, then slice your biscuit dough in strips about the same as the pork and crosswise, leaving about an inch between each strip. Repeat this operation until you have used up your material, having the biscuit dough on top; then pour down the side of the kettle carefully a cup of boiling water, cover and cook slowly for one hour and a half, adding boiling water when necessary. This is delicious when served with whipped cream.

43. Apple Pie Decorated with Cream and Chcese-Make an apple pie after your favorite recipe. Have ready a cream cheese, press through a ricer, cut and fold into the cheese a cup of double cream beaten until solid; add a few grains of salt. Put this mixture through a pastry tube, in any pattern, on top of the pie. Serve as a dessert at either luncheon or dinner.

44. Date and Apple Pie.-Line a pie plate with a rather rich crust; fill it with a mixtule of chopped dates and apples, sprinkle over half a cup of sugar and one teaspoonful of cinnamon; add two tablespoonfuls of water, cover with a top crust and bake about one half hour in a moderate oven.

45. Apple Peanut Salad.-Pare, core and chop slightly acid apples and mix them with half as much chopped celery. Mix a dressiug of peanut butter, using five tablespoonfuls of lemon juice to one tablespoonful of peanut butter. Mix dressing through the apples and celery and season with salt and cayenne pepper. Chill the salad and serve on lettuce and garnish with peanuts.

46. Apple, Orange and Pench Salad.-Equal parts of apples, peaches and oranges are cut into cubes and mixed with cream dressing. Serve in apple shells or in the rind of oranges.

47. Apple Chicken Salad.-Take six ripe apples and scoop out the centers; fill them with cold cooked chicken, minced fine, seasoned with finely minced green peppers and salt, with enough cream to moisten. Place apples in a steamer and cook until aimost tender. Put them on ice and serve with mayonnaise on lettuce. 
48. Apple Salad.-Chop one half pound of cold veal or lean pork and two large tart apples; add two chopped pickles, one tablespoonful of olive oil, one tablespoonful oi vinegar, season with salt and pepper and mix with mayomaise dressing.

49. Apple and Cabbage Salad.-Shave cabbage fine and soak for one hour in celery water, made by adding one teaspoonful of celery salt to each quart of water. Drain and dry on a soft towel. Add an equal amount of apple cut into match-like pieces; mix with boiled dressing.

50. Apple and Chcese Salad.-Mix some chopped pecans with twice their bulk of cream cheese, adding a little thick cream to blend the mixture. Season with pepper and salt and make into tiny balls. Pare mellow, tart apples, core and slice across the center into rings about one half inch thick, then arrange rings on lettuce leaves and place sereral cheese balls in the center. Serve with cream salad dressing. 
CHAPTER XIX.

\section{INSECTICIDES AND FUNGICIDES.}

In spraying the apple for the eonterol of the various inseret pests and lumeous diseases that afferet this fruit, there are many different formulat nsed. the principal of which are wiven herewith, under the hradinges ('ontact Insecticides, Poisonous Insecticides and Fungicides.

\section{CONTACT INSECTICIDES.}

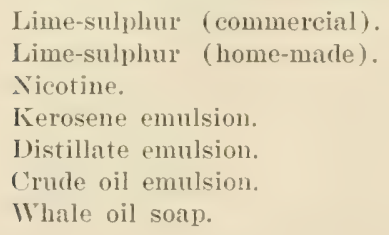

\section{FUNGICIDES.}

Bordeaux mixture.

Lime-sulphur (commercial).

Lime-sulphur (home-made).

Lime-sulphur (self-boiled).

Iron-sulphid (see Apple Miłlew).

Atomic and Millerl sulphur.

\section{SPRAY FORMULEE.}

\section{Lime-Sulphur-Commercial.}

Practically erery insecticide company manufacturess lime-sulphun. ronserpuently there are a speat many different hrands on the market. most of which are good. This material comes in liquid form and is diluted with water, using 1 part of the liquid to 10 parts of water for a dormant spray, and 1 to 35 for summer use on apples.

Lime-Sulphur-Home-made.

Stoue lime
Sulphur - 40 pounds.
Water

Preparation.-Bring about 50 gallons of water to a boil in some snitable vessel, or a sufficient amount for slaking the 40 pounds of lime. Ard the sulphur and mix as well as possible with the water. When the water is hot put in the lime, which will slake almost instantly with the generation of a great amount of heat. This is desirable, as it helps effect a combination of the lime and sulphur at the start. The mixture shomld 
now be boiled for at least 45 minutes. When finisherl it is a bright real rolor, which often turns olive green upon further boiling. There is no danger of boiling too long, but on the other hand too little boiling may be responsible for a poor spray.

Lime-sulphur is one of our best insecticides, as well as fungicides.

\section{Nicotine.}

For the various plant lice which affect apples there is nothing better to apply during the summer season than nicotine, in some form or other. The most commonly used nicotine spray is Black Leaf " 40 ," and it is usually applied at the strength of 1 part of water to 1000 parts of the nicotine solution. The addition of 5 pounds or more of soap to 100 gallons of the diluted spray adds to its efficiency.

\section{Kerosene Emulsion.}

Water
Kerosene 1 gallon.
Hard soap -

Preparation.-Bring the gallon of wates to a boil and dissolve the soap in it; while hot add the kerosene, agitating the mixture violently for fifteen minutes or more. A cream-like emulsion should be formed, which will mix readily with cold water. A stock solution, containing $66_{3}^{2}$ per cent oil, is obtained by this process, and may be diluted to any desired strength.

H. F. Wilson, of the Oregon Agricultural College, gives a simple method for determining the strength to be used. which is as follows: Divide 200 by the per cent desired. and subtract 3 ; this will give the amount of water necessary to add to each 3 gallons of stork solution for the desired per cent. Example: A 15 per cent solution is desired; 200 divided by 15 equals $13: 3$. minus :3 equals $10 !$; this amount of water added to 3 gallons of stork solution will give the 15 pere rent emulsion

*Distillate Emulsion.

Distillate (2S Baumé)
Whale oil soap

Preparation.-Dissolve the whale oil soap in the water, heating it to the boiling point; add the distillate and agitate thoroughly while the solution is hot. For use add from 10 to 20 gallons of water to each gallon of the above mixture.

\section{*Crude Oil Emulsion.}

Water
Liguid soa!
Crude oil 175 gallons.

P'r paration.-Fill the spray tank with the 175 wallons of water a add the lirpuid soap); agitate thoroughly for ome minule, after which adt the crude oil, continuing the agitation.

\footnotetext{
*Copied from "Injurious and Beneficial Insects of California," by E. O. Essig.
} 
If the liquid soap can not be had, use 20 pounds whale oil soap, dissolved in 10 gallons of boiling water, to which 3 pounds of lye have been added.

\section{Whale Oil Soap.}

This soap is often used in combination with nicotine sprays, to inerease their penetration and spreading qualities. Alone as a spray for apple aphids it is very valuable, when used at the strength of 1 pound ot soap to 5 gallons of water.

The ordinary form of this soap has to be melted before being used. There is, however, a liquid form on the market which is much more conveniently handled.

\section{Arsenate of Lead.}

This is the most "ommonly used arsenical spray in the apple orchard, and ordinarily is applied at the strength of 3 pounds paste to 50 gallons of water. This anount is sufficient to kill codling' moth, canker worm, tont caterpillar and other larva which feed upon foliage and fruit. A powdered form of arsenate of lead is also on the market and should be used according to the directions on container.

\section{Paris Green.}

In the past this arsenical poison has been very extensirely used in spraying for the control of chewing insects, but its use has been superseded by the safer and generally better arsenate of lead. For codling moth and other chewing insects it should be applied at the strength of pound to 100 gallons of water. On account of the likelihood of there being more or less soluble arsenic in the Paris green, which may blight the foliage. lime in small quantities should always be added to the spray. Five pounds of stome lime, slaked, to every 100 gallons of liquid is sufficient.

\section{Arsenite of Zinc.}

The above is one of the newer arsenical insecticides, and gives splendid results in killing certain insects, which are more or less resistant to arsenate of lead poisoning, as well as all those for which the arsenate of lead is used. It is a less stable compound and for that reason considerable damage has been done to trees and fruit because of its having burned the foliage. It is probably safe for the calyx application in spraying for codling moth.

\section{Bordeaux Mixture.}

Copper sulphate 10 pounds.
Stone lime (unslaked) 10 pounds.
Water …n.

Preparation.-The copper sulphate is first dissolved by suspending the weighed amount in a sack, in a sufficient quantity of water. The lime is slaked in an equal amount of water and the two liquids poured together into the spray tank, where the agitator will keep the liquid properly mixed. 
This is one of the oldest fungicides, and one which we might term the standard.

Lime-Sulphur (Self-boiled).
Stone lime $\quad \mathrm{S}$ pounds.
Sulphur $-\mathrm{S}$ pounds.
Water

I'reparation.-The preparation difters from that of the home made boiled lime-sulphur, in that only the heat of the lime, which is generated during the slacking process, is utilized. It is made in a barrel or tank, which may be covered tightly to retain the heat for about 15 or 20 minutes, when a slight amount of the sulphur and lime will have combined. It is diluted with cold water, after being strained.

In some of the states to the east the self-boiled lime-sulphur alone, or in combination with arsenate of lead, has been used repy successfully for apple scab and mildew: but has not been generally recommended under California conditions.

\section{Atomic or Milled Sulphur.}

Very tinely divided sulphur may now be purchased for spraying purlioses. The forms known as "Atomic" and "Nilled" sulphurs are comnonly used for mites with great success, and are excellent mildew fungieides. The directions for mixing come with the packages. 



\section{INDEX.}

PAGE

ACREAGE, by counties_._.

Yellow Newtowns and Yellow Bellilowers in Pajaro Valley_._.......... 2?

AGE, influences size of fruit

one year old tree best_...

ALEXANDER _.

ALSOPHILA POIETARIA_.

ANNUAL PRUNING__.......

APHELINUS MALI__.

APHIS, avent

bakeri _.

destruction of young grafts___. 61

gossypii _-

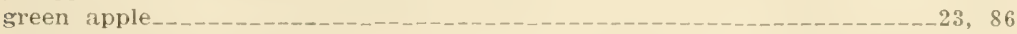

medicaginis _. 88

other apple species_._- 87

pomi _...

purple aphis_-

sorbi _-

species affecting the apple ... _. _ _...

woolly aphis_____.

APPLE, acreage bearing

acreage non-bearing

age to plant

budding -

butter _- 102

crab _-

deep rooting trees desirable

insect pests of

propagation of

root-grafting _

seedlings -

selection of trees for planting _....... 35

summer varieties_._.

ARCHIPS ARGYROSPILA

ARKANSAS -

ARKANSAS BLACK

ARIILLLARIA IIELLEA _.

ARSENATE OF LEAD

ARSENITE OF ZINC

ASPHALTUM FOR TREATING WOUNDS

ASPIDIOTUS PERNICIOSUS

ATOMIC SULPHUR _......

BACILLUS AMYLOVORUS

BACTERIUM TUMEFACIENS_ _. _ _ _ _ _ _ _ _ _ _ _ _ _

BAILEY SWEE'T-_-_-

BALDWIN _...

BALDWIN SPOT _. _ _.

BALLARD, W: S._.

BANANA _.

BEN DAVIS . . $\ldots \ldots \ldots \ldots \ldots \ldots \ldots, 16,36,72$

BENTON, J. F.

BIETIGHEIMER _.

BLACK BEN_...

BLACK LEAF $40 \ldots$

BLIGHT -

BLISTER MITE

BLOOMING OF VARIETIES

BORDEAUX MIXTURE__....

BORERS, conditions favorable for

flat headed of apple

BOYD, E. N. 
BRACING, NATURAL

BREMNER, O. E.

BROWN MITE

BRYOBIA PRATENSIS

BUDDING:

in new growth of old trees.

operation of

BUDS, for budding purposes

health promotes frost resistance.

only healthy should be used for budding-

selected carelessly for budding.

tying of

BUD-WOOD

BY-PRODUCTS

CALYX SPRAY FOR CODLING MOTH

CANADA RED

CAPILLARITY OF SOILS

CHAMPION

CHENANGO

CHIONASPIS FURFURA

CHRYSOBOTHRIS FEMORATA

CIDER

CLEFT GRAFTING

CLIMBING CUPWORMS

COAL HEATERS FOR FROST PROTECTION

CODLING MOTH control of

life history of

$\ldots+\ldots, 67,65$

$76,78,79,81,82, \$ 3,84,114$

79, So

COMMERCIAL FERTILIZERS

CONSUMPTION OF APPLES

CONTACT INSECTICIDES _ _

COOK'S SEEDLING__.

CORROSIVE SUBLIMATE, disinfectant____

COVER CROPS_._.

CRAB APPLES .............

CROPPING PREVIOUS TO SETTING TREES _...

CROSS POLLINATION

CROWN GALL

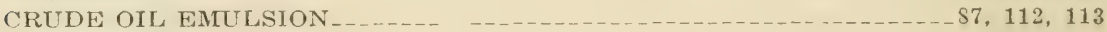

CULTIVATION _-_

CUT-TWRMS, climbing

DELAWARE RED

DELICIOUS _

DEPTH TO PLANT

DISEASES OF THE APPLE

freedom from

DISTILLATE EMULSION____

DRIED APPLES

DUST MULCH

DYNAMITING FOR HARDPAN

EARLY HARVEST

E.IPOASCA MILI__._.

ERIOPHYES PYRI__.

ERIOSOMA LANIGERA

ESOPUS -

ESSIG, E. O.

FALIAWATER _...

FALI CANKER WORM

FALL PIPPIN

FAMEUSE

FEMMONS, FRANK

FERTILIZERS _

FIRING FOR FROST PROTECTION

FLAT HEADED APPLE TREE BORER

FLAT HEADED BORERS 
I'AG:

FLORENCE CRAB

FOURTH AND FIFTH SEASON PRUNING

FROST, early blooming varieties affected by

injury from

orchard heating to prevent injury from

protection from

relation to apple growing

smudging to control____-

susceptibility of varieties to injury from

FRUIT SPURS DEVELOPED BY SUMMER PRUNING

FUNGI, rot

FUNGICIDES -

GANO _......

IILLET'TF, C $\quad$ P.

GLORIA MUNDI _

GRADING

GPAF'TING -

methods of

selection of stock for

waxes -

IRAVENSTFIN

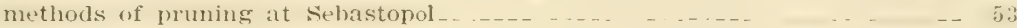

show at Sebastopol

(YRAY, GEO. P.

GREEN APPLE APHIS

GRIMES -

GRIMES GOLDEN PIPPIN

GYPSUM IN SOILS

HARDPAN _.

breaking with dynamite

HARROWING _...

HASSLER, J. E.

HEATING THE ORCHARD

HEMEROCAMPA VETUSTA _ _

HEXAGONAL SYSTEM FOR PLANTING _.

HOLES, digging for trees

filling in

HOOVER -

HOSE FOR SPRAYING

HUMUS -

HYSLOP CRAB

II.LUSTRATIONS-

boxes of fruit stored in packing house, fig. $52 \ldots \mathrm{S}$

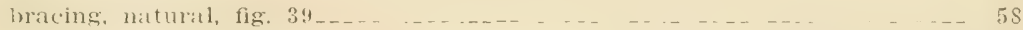

budding operations, figs. 17, 18, $19 \ldots$

calyces right for codling moth spray, fig. $48 \ldots$

carton for apples, figs. 55, $56 \ldots$

Delicious, fig. 3 . _ _

Delicious tree, heavily loaded, fig. 4

framework, crowded, fig. $27 \ldots$

framework formed with three branches, fig. $29 \ldots \ldots$

frost injury, figs. $45,46 \ldots$

frost russet, fig. $47 \ldots \ldots$

Gravenstein, fig. 5

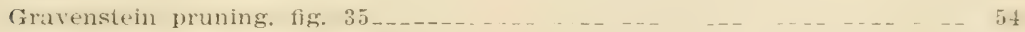

Gravenstein well headed, fig. $36 \ldots \ldots \ldots \ldots$

Grimes, fig, 6_.

growth of heavily pruned Winesap, fig. 33

heavily pruned young WVinesap, fig. 32_ 51

jelly exhibit, fig. $57 \ldots \ldots 3$

Jonathan, fig. 7 . .

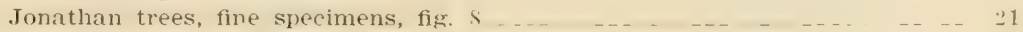

Jonathan tree, well loaded, fig. 9

mildew on apple twig, fig. $50 \ldots$ 
ILIJTSTRATIONS-Continued.

orchard at Tehachapi, set well, fig. 24

orchard scene near Julian, fig. 2

orchard scene near Sugar Pine, fig. 1 $1 \ldots \ldots$

packed boxes, Yellow Bellflowers, fig. 53 59

packed box showing bulge, fig. $54 \ldots \ldots$

picking bucket, fig. 51

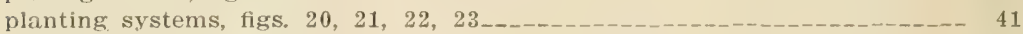

Rome Beauty, fig. $10 \ldots \ldots-23$

Rome Beauty, young tree, fig. 11_. 24

Saw, pruning, fig. $40 \ldots$

scab on apple, fig. $49 \ldots$

Sebastopol Apple Sliow Exhibit, fig. 58

second season pruning, figs. $30,31 \ldots 50$

setting board, fig. 25

shears, pruning, fig, $41 \ldots$

shears, thinning, fig. $44 \ldots$

Stayman Winesap, heavily loaded, fig. 12_... 25

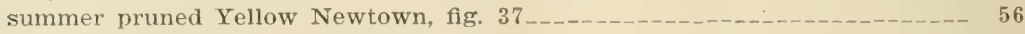

third season pruning, fig. $34 \ldots$

tillage well cared for, figs. $42,43 \ldots \ldots \ldots+\ldots \ldots$

tree shown in figs. 32,33 , pruned, fig. $33 a \ldots \ldots \ldots$

unpruned, branches slender, fig. $28 \ldots \ldots$

Winesap, fig. 14_. 27

WinterPearmain, fig. $13 \ldots \ldots$

Yellow Bellflower, fig. 15

Yellow Newtown, fig. $16 \ldots \ldots$

Yellow Newtowns on summer pruned tree, fig. $38 \ldots \ldots 7$

young tree cut back when set, fig. $26 \ldots$

INSECTICIDES _. _ _ _...

INSECT PESTS OF THE APPLE

INSPECTION BY COUNTY HORTICULTIRAL COMMISSIONERS-_ _... _.. 37

INTERCROPPING _

IRON SULPHIDE

IRRIGATION _-

difficult with improper leveling

influence of plowing upon

influence upon frost

of young orchard

relation to intercrops__. 62

JELLY, apple

exhibit at California Apple Show

JONATHAN _

relation of early blooming to freezing

spot disease of

JULIAN DUCHESS

KENTUCKY RED STREAK

KERF GRAFTING__

KEROSENE EMULSION

KESWICK CODLING_-

KING -

KING DAVID . .

IAABELS FOR BOXES

I.ANKFORD

LAWVER

LAYING OUT ORCHARD TRACT

IEAD PAINT FOR WOUNDS__

LEAF HOPPER OF THE APPLE

LEAF ROLLER OF THE APPLE

LEGUMES

LEPIDOSAPHES ULMI

LEVELING

LIME, addition to soils deficient in

for whitewash

use with Paris green 
LIME-SULPHUR $86,88,93$

commercial

homemade

MACHINES FOR SPRAYING

MACKAY, L. GERTRUDE_

MAIDEN BI,I'SH _

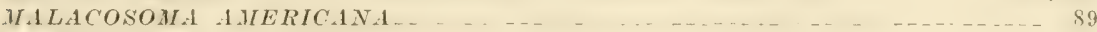

MALACOSOMA DISSTRIA___

MAMMOTH BLACK TWIG

MANN -

MARL _. _ _ _ _ _ _ _ _ _

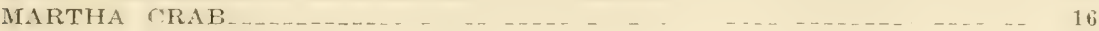

MASKEW, FREDERICK_.

MATURE TREE PRUNING

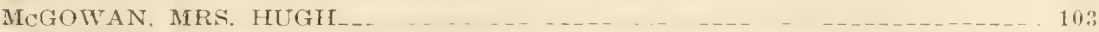

MCINTOSH _._.

MCMAHON WHITE__._.

IIECHANICAL GRADERS_._-

MILDEW _ affecting Yellow Newtowns powdery of the apple

MILLED SULPHUR _-_

MINERAL NITRATES.

MINKLER _...

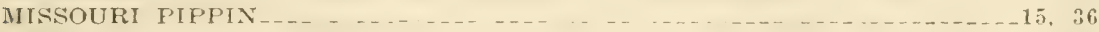

MITES -

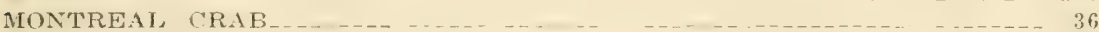

NATURAL BRACING

NATURAL ENEMIES OF THE WOOLLY APHIS _ _ _... _ _ _ _ _...

NELSON, PROF, J. W.

NICOTINE _. _ _

NITRATE OF SODA, SPRAYING

NITROGEN -

NONE-SUCH

NURTHERN SPY _ _...

NORTHWESTERN _ _

NOZZLES -

NUMBER OF TREES PER ACRE _.

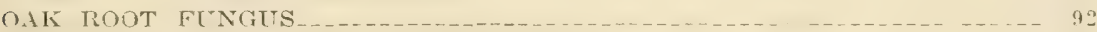

OIL HEATERS FOR FROST PROTECTION _........

OLDENBERG _...........

ORANGE PIPPIN _......

ORCHARD HEATING_.

ORTLEY _

OYSTER SHELL SCALE

PACKING _-

size of boxes and styles of pack

special packages

PACKING HOUSES HARBOR CODLING MOTH

PAINTING WOUNDS____

PALEACRITA VERNATA _

PARAGON

PARIS GREEN

PARTHENOCARPIC DEVELOPMENT OF FRUIT__........ 70

PEWAUKEE

PICKING:

PIPING SYSTEM OF SPRAYING

PLANT FOOD, healing by

taken from soil by cover crops

PLANTING number of trees per acre

preparation of solls for

selection of trees for

systems - 
PAGE

PLANT LICE.

PLOWING -

PLUM CIDER _

PODOSPHARA LEUCOTRICHA

PODUSPHERA OXYACANTHAE

POINTS ESTABLISHED FOR TREES IN SETTING_.

POISONOUS INSECTICIDES _

POLLINATION OF VARIETIES _

POWER SPRAYERS

PRODUCTION _-

PROPAGATION _._.

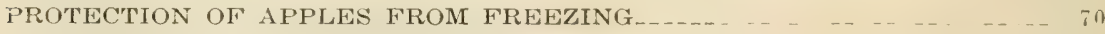

PROTECTORS FOR YOUNG TREES _ _

PRUNING _.. annually _...

cutting to outside buds__. 55

fourth and fifth seasons... 54

heavy with Jonathan

height of head......... 46

influence of variety on

influence upon frost $\ldots \ldots \ldots \ldots$

low heading

mature trees........... 56

saw

second season ... _...

shears

summer _-

third season____ 52

to control mildew

young tree when set___n_. 46

PURPLE APPLE APHIS

QUESTIONS SENT TO APPLE GROWERS

QUINCUNX SYSTEM FOR PLANTING

RAFFIA BUDDING FIBRE,

RAKER, JUDGE J. S....

RALLS -

RAMBO

RECIPES - _.

RED ASTFACHAN _ _ $\ldots \ldots \ldots \ldots \ldots \ldots \ldots$

RED HUMPED CATERPILLAR _

RED JUNE_-_

RED PEARMAIN _.

RED WINTER

REED, HAYWARD $\ldots \ldots$

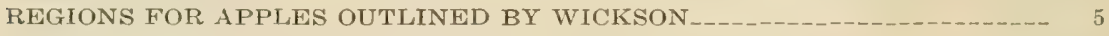

RESISTANT VARIETIES TO WOOLLY APHIS ATTACK______

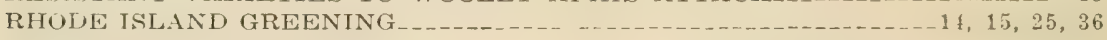

RODENTS, protection against__.

RODGERS BROS.

RODS FOR SPRAYING

ROMANITE -

ROME BEAUTY late blooming habit_____

pruning of

ROOT'GRAFTING

ROO'T-HAIRS

ROOTS, SEEDLING

ROOT SYSTEM DAMAGED IN DIGGING_.

ROT-FUNGI

ROWE, GEORGE

RUSSETING FROM FROST

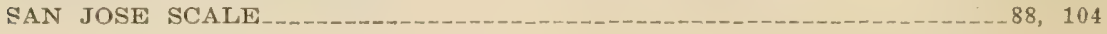


affecting Yellow Newtowns__.

description and control of _... . _ _ _ _

knowledge necessary in spraying for

SCALE, San Jose, scurfy and oyster shell

SCHIZURA CONCINNA _

SCIONS _

SECOND CODLING MOTH SPRAY

SECOND SEASON PRUNING

SEED, instructions for sowing

SEEDLINGS _

roots -

union of buds with stem

SETTING BOARD__

SHEEPNOSE

SHEIIFH - _ _..

SHOCKLEY _-

SIBERIAN CRAB

SMITH _.. _......

SMOKEHOUSE -

SMUDGING

SOIL _-

baking of

deficiency of nitrogen__._. 62

hardpan _ _ _.......

Norfolk sandy loam____ 39

Portsmouth sandy loam

retention of moisture

SPITZENBERG -

SPRAY FORMUIALE_ _ _ _ _ _

SPRAYING _...

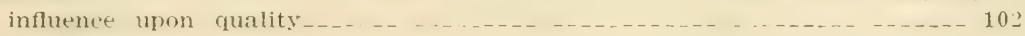

machines _-

piping system of

quantity of material for

SPRING CANKER TVORMT _._.

SQUARE SYSTEM FOR PLANTING TREES

STANDARDIZATION METHODS AFFECTED BY THINNING_._._._. 67

STARK - -

STATISTICS, tables of ____

STAYMAN WINESAP__

STUBS _.

SUMMER, cultivation

pruning -

varieties

SUN-BORERS _-

SUN-SCALD _-

SUTTON _...

SWAAR, -

TAYLOR, E. P.....

TENT CATERPILLARS

TERMITES -

THERMOMETERS FOR ORCHARD HEATING WORK

THINNING -

necessary for best results___- 27

of Gravensteins _....... 19

THIRD CODLING MOTH SPRAY

THIRD SEASON PRUNING

THOROUGHNESS IN SPRAYING $\ldots \ldots \ldots \ldots$

TOLMAN _._.

TOP-WORKING APPLE TREES

TRANSCENDENT CRABS

TREATMENT OF WOUNDS_

TREE PROTECTORS _-

TRIANGULAR SYSTEM FOR PLANTING $\ldots \ldots \ldots \ldots$ 
TUSSOCK MOTH____.

TWENTY OUNCE

UTTER …

VARIETIES, adaptation of

cross pollination of _. 35

description of

list of

selection of for planting

self fertility of

size varies with

supplementary list of _.......

undesirable should be removed...

variation in time of blooming

TENTURIA INAEQUALIS_.

TINEGAR _.

VOLCK, W. H.

WAGENER _

WALBRIDGE

WALTERS, S. A.

WATER SPROUTS___

WAXES, grafting _._.

WEALTHY _.

WELDON, MRS. GEO. P._.

IVHALE OIL SOAP____

WHIPPLE, PROF, O. B.

THHTE BELLFLOWER _

WHITE PIPPIN _._.

WHITEWASH

WWHTNEY CRAB

TVICKSON, PROF. E. J.

IVILSON, PROF. H. F.

WINESAP _

WINTER BANANA _

WINTER PEARMAIN____

WOLF RIVER

WOOLLY APHIS_____

WOUNDS, treatment of _._.

WRAPPING PAPER

YELLOW BELLFLOWER_______... $5,14,15,22,28,30,35,36,71,72,99$

YELLOW NEWTOWN___ _ _ _ _

YFLLOW TRANSPARENT_ _...

YORK IMPERTAL__

YOUNG TREES, caring for 











\section{LIBRARY OF CONGRESS \\ ||||||||||||||||||||||||||||||||||||||||||| \\ |||||||||||||||||||||||||||||||||||||||||||||||||||| \\ 00009⒐ 348}

